\title{
"Within and Without": Exploring the Mind in the Novels of George MacDonald
}

By

Saskia Voorendt

\author{
A thesis \\ submitted to the Victoria University of Wellington \\ in fulfilment of the requirements for the degree of \\ Doctor of Philosophy \\ in English Literature
}

Victoria University of Wellington

2012 


\section{Acknowledgements}

The completion of this project would not have been possible without the unwavering support and academic guidance of my two amazing supervisors, Kathryn Walls and Heidi Thomson. Their ongoing commitment, ruthless editing, and inspired insights have proven invaluable over the last three years.

I would also like to thank the staff and post-graduate community of the English Department at Victoria University of Wellington, for providing such an encouraging and supportive academic environment in which to work. In particular, I would like to thank Lilja Sautter for her assistance (and patience) in translating and discussing the work of von Schubert. Special thanks must also go to my long-suffering office companion, Lujan Herrera, not only for putting up with me and my eccentric study habits for three years, but also for accompanying me around the north of Scotland in search of people and places relating to George MacDonald.

Thank you to the scholarships office of Victoria University of Wellington for providing me with the financial means of pursuing my academic goals, not only here in Wellington, but also overseas for research and conference purposes.

Finally, I would like to acknowledge that tremendous source of inspiration and support that is my circle of family and friends. Their incredible understanding, encouragement, and belief in me cannot be lauded enough. 


\begin{abstract}
George MacDonald's first published novel, Phantastes, is the story of a young man who enters and must negotiate his way through a fantasy landscape. This landscape, it is suggested, is one of the mind, and Anodos' journey through it one of selfexploration and discovery. The sustained metaphor of the mind as a territory to be actively explored through the medium of the physical world, furthermore, is argued to be the basis of several of MacDonald's novels. While for Anodos the mind is all, forming as it does the basis of the entire fantasy world of Fairy Land, in the author's numerous realist texts the interest emerges in more varied ways, including for example, portrayals of depression, madness, and drug (ab)use. While this significant and unifying feature of MacDonald's novels has been at times observed by critics with regard to some individual texts, it has not been directly confronted in terms of an inclusive study of his oeuvre.

What this thesis demonstrates is firstly the overwhelming significance of the mind as a focal point for MacDonald's novels, as represented by six central texts: Phantastes, Adela Cathcart, Wilfrid Cumbermede, Malcolm, Donal Grant, and The Flight of the Shadow. It is suggested that such a consistent prioritising of the mind over the physical body lies in the author's own experience of ongoing physical illness and resulting confrontation with mortality. The mind becomes, for MacDonald, a means of negotiating the relationship between the realms of the physical and the spiritual. In Phantastes, for example, Anodos' physical experience (achieved through the genre of fantasy) of his own mind in Fairy Land, concludes with reference to the afterlife. The mind in this (and MacDonald's other novels) provides the means by which transcendence is achieved.
\end{abstract}




\section{Table of Contents}

Acknowledgements

Abstract

Introduction: "Breaking Forth from the Dream Home"

Chapter One: "Self will come to Life": a landscape of the mind in Phantastes

Chapter Two: "Beginning from the Inside": healing stories Adela Cathcart

Chapter Three: "The Course of this World": resisting temptation in Wilfrid Cumbermede

Chapter Four: "A Tortured Mind": madness in Malcolm

Chapter Five: "Home-born Phantoms": the drugged mind in Donal Grant

Chapter Six: "Darkness that Haunts": guilty minds in The Flight of the Shadow

Conclusion: "The New Childhood"

Works Cited 


\section{Introduction:}

\section{"Breaking Forth from the Dream-Home"}

The texts chosen for this study have been selected to represent the scope and variation of George MacDonald's literary vision. MacDonald's writing career spans five decades, and so the selection has been made with the progression of his ideas throughout this period in mind. Each engages with a concept of the individual's mind - in interaction with the physical and spiritual environments. Chapter One focuses on the author's first novel, Phantastes (1858), in which the main character enters a fantasy world, a landscape akin to that within his own mind. Chapter Two discusses Adela Cathcart (1864), a contrastingly realist work which nevertheless highlights the roles of the mind and the imagination in constructing (and maintaining) individual health. Wilfrid Cumbermede (the subject of Chapter Three; 1872) uses the genre of the bildungsroman to depict both the search for identity and the fulfilment of spiritual enlightenment. Chapters Four and Five explore differing states of consciousness (achieved through madness and drugs, respectively) with reference to Malcolm (1875) and Donal Grant (1883). Finally, Chapter Six focuses on one of MacDonald's later novels, The Flight of the Shadow (1891), which engages more directly with the fantastic in a realist context. For MacDonald, the human mind was a site of potential trauma: trauma brought about by the mind's precarious existence on the border between a physical reality and a spiritual ideality. A strong influence on such a conception of the mind, I will argue, was the author's own early life experience.

\section{"A feverish urge": physical illness and the imagination}

Writing to the The Spectator in July 1867, MacDonald declares, "[s]urely it is one of the worst signs of a man to turn his back upon the rock whence he was hewn" (Greville MacDonald 38). MacDonald's personal history, including his own childhood experiences, proved a powerful influence on his writing, and evidence of its significance in relation to his imaginative vision can be found throughout his oeuvre. It appears in his realistic novels and his fantasies, and affects action, 
character, and setting. As William Raeper notes, "The Farm [his childhood home] features largely in MacDonald's writing. It was an important reference point for his imagination. It was where his childhood was played out and his memories return to it again and again" (George MacDonald 23).

A persistent presence in MacDonald's childhood was physical illness, and in particular tuberculosis, from which MacDonald was to suffer not only in childhood but throughout his life. One might expect then that the illness would make an appearance in MacDonald's own writing. After all, tuberculosis as a literary subject was increasingly popular in novels of the nineteenth century. Writers tuberculous themselves, or otherwise surrounded by it, employed the disease in abundance in their plots (Dormandy, The White Death 92). But despite MacDonald's personal experience of tuberculosis, it is - on the face of it - strikingly absent from his novels. ${ }^{1}$ A closer examination of MacDonald's novels, however, reveals its subtle influence. As is well-recognised, MacDonald treats his subjects symbolically, and tuberculosis, in so far as it makes an appearance in his novels, is a case in point. Instead of making explicit use of the disease as a device, or instrument of plot or character development, MacDonald uses it as a metaphor. As we shall see, the symbolic value of the disease allows the author to explore broader issues of identity and its impact on the individual. It also draws attention to the relationship between the physical and the spiritual. Before elaborating on this point, however, I need to dwell at greater length on the status of tuberculosis in MacDonald's life-time.

As the literary scholar Katherine Byrne has demonstrated, tuberculosis (otherwise known at the time as "phthisis," "consumption" or "decline") killed more people than cholera and smallpox combined during the Victorian era (1). At its height early in the nineteenth century, a fifth of all deaths in England could be attributed to it, and (while numbers declined from around 1830) it remained throughout the Victorian period as (according to Byrne) "the biggest single killer of men and women in their physical and productive prime" (12). In 1825, when George MacDonald was just a year old, his father's left leg was amputated above the knee for tuberculous disease of the joint, after two years of unsuccessful treatment (Greville MacDonald 34). His mother had been suffering from the disease for many

\footnotetext{
${ }^{1}$ An online search of MacDonald's novels on Project Gutenberg shows "consumption" employed occasionally as a term denoting general illness in predominantly secondary characters. There is no mention of "tuberculosis" or "phthisis."
} 
years, before dying from it in 1832, when George was only eight (Greville

MacDonald 31). James, the third child and next in age to George, died in 1834, when he was just eight and George ten, and John McKay, born in 1829, died in infancy.

As for George himself, he was, in Greville's words, "a delicate boy" despite his robust enthusiasm for the outdoors (58). He was often kept from school (once confined to his bed for four months), and "play was often mixed with illness" (29). He was apparently susceptible to pleurisy, a disease often associated with tuberculosis. ${ }^{2}$ Writing to his father from Portsoy on 15 August, 1833, the young George MacDonald recorded that he had been "unwell for two or three days, my throat $[\ldots]$ a little sore and my head very painful but I $[\ldots]$ have been in the sea today and like it very much." 3 Sea bathing and even the drinking of sea water having been regarded as therapeutic at the time, it is significant that he wrote, also, that his aunt had made him drink the water despite his reluctance, and (in the following year from Portsoy): "I have bathed every day since I came and I drink the salt water every two days" (Sadler 6). ${ }^{4}$

George MacDonald's own ill health continued to influence his life once he left Huntly to attend university in Aberdeen. "The Aberdeen student," writes Greville MacDonald, "would work on the land during the seven months of summer and earn enough for the five at college; and he would come on foot a hundred miles or more [...]. But George MacDonald was physically unfitted for such work" (72). His ill-health continues to appear as a subject in his letters home. On 5 January 1841, for example, he wrote to his father, "I think it would be better [if I had] some of the stuff which the Doctor used to give [his brother Alex] and me. The glands at the back of my ear have been a little swelled and painful for some time" (Sadler 8). Ill health dogged his early adulthood, too. After taking his degree and gaining a

\footnotetext{
${ }^{2}$ For details of this connection, see Joseph Coats and Lewis R. Sutherland, A Manual of Pathology (1900).

${ }^{3}$ For references to MacDonald's letters, see Glenn Edward Sadler's An Expression of Character: The Letters of George MacDonald (1994).

${ }^{4}$ On the therapeutic effects of sea bathing, Dr Martine, for example, claimed in 1631 that " all the phisick in the world' would not equal the cure that could be achieved by drinking Cromer sea water (Hassan 16). According to John Hassan, by the end of the seventeenth century "doctors were regularly recommending the sea cure in their writings about gout and melancholia" (16). In 1752, Dr Richard Russell advised seawater therapy as treatment for such conditions as leprosy and cancer (Hassan, 6). It was from around this time that "fashionable society" headed to the coast, in the pursuit of the healthy benefits of bathing in and drinking seawater. "Seabathing infirmaries" sprang up at Margate in 1796 and Scarborough in 1812. The Margate hospital "sought especially to offer treatment to sufferers of scrofula, a tuberculosis of the bones and lymphatic glands" (19).
} 
position as a tutor in a London family, MacDonald's letters continue to contain frequent references to illness. Thus, on 8 November 1845 he wrote that his health was still "not very good" and that he needed medication "pretty often" (12), while in December he claims, "I am much better than I was in Scotland, and if I get off without a bad cold this winter, which I have not yet had, I expect to be very well next summer" (13). Despite this optimism, however, two years later, on 11 April 1847, he writes home again from London that he has "had a bad cough for some time \& [am] not strong" (16); furthermore, that "I scarcely think [...] that I can agree to stay another winter without they give me a fire in my room, for my illness is owing a great measure to sitting in the cold" (16).

Interest in his own health led MacDonald to explore different forms of treatment. In October 1850, for example, he wrote (to his father, from Arundel, where he had accepted a pastorate) of his induction to homeopathy (39), and in November (more seriously, to his fiancée Louisa) of "a broken bloodvessel and furious haemorrhage from the lungs", which forced him to "lie motionless on his back, with leeches on his chest" (Greville MacDonald 144). Later in November he wrote again to his father that his doctor had ordered him "not to preach for six weeks or two months. He has ordered me cod-liver oil. ${ }^{5}$ I have very little fear that my complaint is slight and will soon leave me with proper care - But I believe the lungs are in some measure affected" (40), ${ }^{6}$ and in December: "I feel very doubtful whether I shall preach much longer. I feel if I were to begin again now, it would bring back the attack" (17 December 1850, 41).

MacDonald's history of ill-health was, as we have seen, conducive to his interest in therapy, which emerges time and again in his novels. It also affected his conception of the relationship between the psychical and the physical, which is likewise crucial to his writing. It is the process of influence of such physical suffering on the development of the mind that serves as a focal point for MacDonald's explorations of character. The loss of so many loved ones at such a young age must surely have predisposed the author to melancholia, furthermore, and influenced his sensitive imagination. Greville MacDonald writes of an inherent "melancholy" that "dogged his [George MacDonald's] innate gaiety" (52), affecting

\footnotetext{
${ }^{5}$ Cod liver oil was a popular prescription for consumption throughout the century, linked to the association of the disease with malnutrition (Byrne 38)

${ }^{6} \mathrm{He}$ also mentions the presence in the house of another "invalid": "a sister of the late Mrs Powell [...] She has had nearly the whole of her right breast removed for cancer."
} 
him throughout his later boyhood; but he also emphasises the "keener vision" that saw his father privy to "a different world from his playmates"; that it "everywhere disclosed fairyland and bewitchment, chivalry and devotion" (51).

As premised, the impact of physical suffering on the development of the mind is central to a discussion of MacDonald's novels. To briefly anticipate the forthcoming larger discussion on this theme, I will begin with one example. The young protagonist of "A Child's Holiday," one of the stories contained within Adela Cathcart, recalls the descriptions of the young George in his physical frailty. Thirteen-year-old Herbert is described as, "a boy whom repeated attacks of illness have blanched, and who looks as if the thinness of its earthly garment made his soul tremble with the proximity of the ungenial world" (Adela Cathcart 316). However, his physical frailty is compensated for in mental advancement. Thus, although only thirteen, he

had already attained a degree of mental development sufficient for characterisation. Disease had favoured the almost unhealthy predominance of the mental over the bodily powers of the child; so that, although the constitution which at one time was supposed to have entirely given way, had for the last few years been gradually gaining strength, he was still to be seen far oftener walking about with his hands in his pockets, and his gaze bent on the ground, or turned up to the clouds, than joining in any of the boyish sports of those his own age. $(316-17)^{7}$

It is Herbert's physical frailty, along with the compensatory powers of his imagination that defines him as a central character. He is singled out from among the other children as an agent of adventure, and the power of his imagination over his physical body lends his story a fantastical dimension. (Herbert befriends a wild orphan, who is seen as a "daughter" of the sea itself.) Because of his "sympathies," Herbert is able to understand the other child, even though it is her imagination rather than logic or reason that characterises her speech: "[i]t seemed that whatever her imagination suggested, bore to her the impress of self-evident truth" (324). Herbert's own imagination is similarly appealed to, as this episode at the seaside is said by the story's narrator to have become, "one of those seasons which tinge the whole of the future life":

\footnotetext{
${ }^{7}$ Greville MacDonald had written that his father, also a young invalid, was "forced to lie in bed and gaze either out of the window or up through the skylight" (29).
} 
It [the holiday] was a storehouse of sights and sounds and images of thought; a tiring-room, wherein to clothe the ideas that came forth to act their parts upon the stage of reason. Often at night, just ere the sleep that wipes out the day from the overfilled and blotted tablets of the brain, enwrapped him in its cool, grave-like garments, a vision of the darkened sea, spotted and spangled with pools of unutterable light, would rise before him unbidden, in that infinite space for creation which lies dark and waiting under the closed eyelids. The darkened sea might be but the out-thrown image of his own overshadowed soul; and the spots of light the visual form of his hopes. So clearly would these be present to him sometimes, that when he opened his eyes and gazed into the darkness of his room he would see the bright spaces shining before him still. Then he would fall asleep and dream on about the sea. (328)

The imagination becomes, in this passage, a physical space in which sights, sounds, and memories give form (or "clothe") the thoughts before their expression. ${ }^{8}$

The idea put forth in the passage of the brain as a tablet to be impressed upon by the day's events, and to be wiped clean again by sleep is also significant. It suggests the concept of tabula rasa ("the blank slate"), the epistemological theory which can be traced back to Aristotle's De Anima, positing that individuals are born without inherent mental properties and any subsequent knowledge gained comes from experience and perception. Herbert's imagination is, in this passage, symbolised by the (imagined) sea itself, the over-arching metaphor of the story. Imagination is presented here as both a space for creation and a reflective surface upon which an image of the soul is realised. Herbert's imagination transcends the border between physical reality and the mind through the idea of perception. His vision of the sea, though found "under the closed eyelids" of sleep or thought, extends into his waking world. The relationship between imagination and reality is thus blurred as also occurs in the wider events of the story. Rather than traditional elements of fantasy, MacDonald invokes the mystery of the mind itself and its potential for creation.

Later in the story, Herbert's imagination reaches its zenith in a dream. This dream, with which the story concludes, becomes (like the holiday itself as earlier described) a defining experience for Herbert's future life: “for it went with him ever

\footnotetext{
${ }^{8}$ MacDonald's first fantasy novel, Phantastes, also makes use of this concept of the imagination giving form to thought, and will be discussed in Chapter One of this thesis.
} 
after, breaking forth from the dream-home, and encompassing his waking thoughts with an atmosphere of courage and hope, when his heart was ready to sink in a world which was not the world the boy had thought to enter" (329 italics mine). This "breaking forth" of imaginative power is the means by which Herbert deals with a disappointing reality, a strategy reminiscent of MacDonald's own in his use of fiction. The creative power of the imagination is not, however, self-perpetuating. It becomes associated for MacDonald with the spiritual, and the means by which the individual communicates with the divine.

MacDonald himself equated his own physical health with that of his spirit, but rather than seeing ill health as influencing his thoughts, he saw one of his more serious attacks to have been brought on by a failure to live by his own beliefs. In the letter to his father of 17 December 1850, he wrote, "I know you have often thought I fancied I could not work and often it may have been so but not always and it is but lately that I said I was sure something would show it was no fault of mine but that something was wrong. It was in the very midst of forcing myself to do what I did not feel as if I were able for that my attack came" (41-42). MacDonald's doubts about his ability to work as a minister within strict sectarian confines are well documented. But his poetic aspirations were as strong as ever at this time, as were his (for that time) eclectic reading tastes. It was during his recovery from this latest attack that he completed the draft of the poem Within and Without (to be eventually published in 1855). It was in 1851, furthermore, while at Arundel, that he worked on a translation of some of German Romantic poet Novalis' poems, distributing them as Christmas presents among his friends.

MacDonald saw his own ill health as intimately connected with (and at least once a consequence of) his spiritual aspirations. But he also thought of it as having positive consequences of its own in terms of the imagination (as was seen in the story of Herbert). The notion that physical illness was conducive to imaginative creativity was a standard one in the period. Consumption in particular was thought to signify a personality type characterised by a highly developed nervous system and resulting heightened sensibility (Byrne 28). The relationship between the two as established historically is not always clear, however, in terms of cause and effect. Edwin Alabone, in The Cure of Consumption (1880), for example, suggested that, "depressing passions and violent emotions of the mind pre-dispose greatly to this 
disease" (24), thus positioning the mental prior to the physical. ${ }^{9}$ In their authoritative 1952 study (The White Plague: Tuberculosis, Man, and Society), René and Jean Dubos isolated what they described as "an enormous literature on the alleged relation between tuberculosis and genius" (59). ${ }^{10}$ It was thought that the intellectually gifted were particularly disposed to phthisis. Consumptive patients were frequently characterised by "a peculiar nervous force" and "feverish urge" for accomplishment. Indeed, it was believed that "the same fire which wastes the body in consumption also makes the mind shine with a brighter light" (59). It was even theorised that a microbial toxin (through a "cerebral intoxication") caused the mental alertness exhibited by so many infected individuals. A "flickering" acumen, which appears suddenly and lasts for a few hours, and which is soon followed by mental depression or fatigue, thus made the consumptive appear as if under the influence of alcohol or a narcotic drug (60). At the same time, confusingly enough, the mental suffering of phthisis was treated by narcotics (Dubos 63). ${ }^{11}$

The belief that phthisis facilitated creativity can also be seen to be based on the huge numbers of famous writers and painters who suffered from consumption. While the symptoms are difficult to interpret in retrospect, several writers in the late eighteenth century probably had tuberculosis. Like MacDonald himself, Jean Jacques Rousseau and Goethe both suffered from lung haemorrhages in their early adulthood, and Friedrich Schiller died from phthisis (Dubos 44). As Dubos suggests, tuberculosis "may have contributed to the atmosphere of gloom that made possible the success of the 'graveyard school' of poetry and the development of the romantic mood" (44). Friedrich Leopold Freiherr von Hardenberg (more popularly known by his pseudonym, Novalis) is perhaps the most pertinent example of the significance at this time of the relationship between tuberculosis and the power of creativity. Novalis is widely considered to be MacDonald's greatest literary influence, and the eighteenth-century poet's own suffering with tuberculosis is seen by critics as having an indisputable impact on his poetic output. Novalis' wider family was also stricken with the disease, as was his young fiancée, Sophie von Kuhn, whose death in 1797 at

\footnotetext{
${ }^{9} \mathrm{I}$ have been unable to locate the primary source of this text, found in Byrne (28).

${ }^{10}$ To complicate things, however, it is also noted that many wasting diseases of the chest were lumped together under such labels as "pulmonary consumption" and "phthisis", diagnosis being then based exclusively on signs and symptoms (Dubos 9).

${ }^{11}$ MacDonald was just as interested in narcotics as he was in consumption, for example when one looks at the characterisation of such characters as lord Morven in Donal Grant (1883), or Teufelsburst in "The Cruel Painter" (from Adela Cathcart).
} 
the age of sixteen inspired much of his later poetry. Historian Thomas Dormandy argues that while Novalis' writing is to many readers almost unintelligible, "many tuberculous patients [...] recognised in it the truest reflection of their own destiny: moments of total despair alternating with almost schizophrenic [...] detachment" (90). MacDonald's adoption of many of Novalis' themes and images suggests that he too found something intensely compelling in that earlier poet's creative vision.

Novalis had (in a fragment, c.1799) written that "the ideal of perfect health is only scientifically interesting" ("Aphorisms," in The German Classics, 1914, vol 4). What is more interesting is sickness, which, as Novalis wrote, "belongs to individualization." Interestingly, as Susan Sontag points out in Illness and Metaphor, it was not only sickness but also sadness that made one "interesting." Sadness was a mark of refinement and sensibility (Sontag 31). According to Sontag, sadness and tuberculosis became synonymous as the myth of the disease continued the extensive history of the concept of melancholy, the artist's disease (32). The melancholy (or tubercular) character stands out as superior because they are "interesting." The connection between the two is significant for a number of MacDonald's novels in which the individualising effects of illness are exemplified. In the case of Adela Cathcart, for example, the plot revolves around the various attempts made by friends and family to effect a cure for the heroine's depression by telling her stories. The individual stories recited by the different characters each focus in some way on Adela and her condition, making the novel the epitome of an exploration of self. The effects of the emotional experience of sadness in this novel reflect those of a physical illness such as tuberculosis. In MacDonald's 1891 novel, Flight of the Shadow (to be discussed in more detail in Chapter Six) it is also sadness which initially defines the character of the narrator's uncle, Edward Whichcote. Furthermore, the sadness proves chronic and is never eliminated. While the novel's narrator, Whichcote's niece Belorba, tries over the course of the novel to connect emotionally with him, her attempts (unlike those of the supportive characters in Adela Cathcart) ultimately result in failure. It is, furthermore, through melancholy (or an attempt at its cure) that Whichcote comes together with his twin brother in the conclusion of the novel, leaving Belorba and her husband John healthy and happily married on the outside of the relationship. Belorba (in her successful attainment of a healthy relationship) is a foil for the emotional intensity of the Whichcote characters. 
In common with tuberculosis and the melancholia associated with it, various kinds of mental illness were thought to distinguish the sufferer as an exile, as one in quest of enlightenment. As Sontag notes, "[t]he TB sufferer was a dropout, a wanderer in endless search of the healthy place" (33), and insanity can be seen as a similar form of exile. The metaphor of the psychic voyage is, as Sontag puts it, "an extension of the romantic idea of travel that was associated with tuberculosis" (36). Sontag has described how insanity came to displace tuberculosis as the means of "bring[ing] consciousness to a state of paroxysmic enlightenment" (36); MacDonald's novels seem to testify to this development. If the illness of Adela Cathcart and the mental preoccupations of Edward Whichcote imply madness, in the character of the melancholy and "mad" laird in Malcolm (the subject of Chapter Four) the connection is explicit. Stephen Stewart, the laird of Gersefell (whose insanity appears to have its roots in Pott's Disease, the spinal form of tuberculosis) is, like the characters of Adela Cathcart and Edward Whichcote, portrayed in a sympathetic light, lending to his madness the quality of transcendence. The laird's achievement of apparent enlightenment in his mad isolation defines the novel as an exploration of self.

\section{"A mine of wealth inexhaustive": MacDonald and the German Romantics}

MacDonald's quasi-Romantic preoccupations, arising, it would seem, from his frequent illnesses, may well have drawn him to German literature and philosophy in which he was certainly well-read. Before I go on to discuss the German influence on MacDonald's writing, however, I need to acknowledge that the German romantic tradition was itself influenced by the English poet, Edward Young, whose Night Thoughts (1742) MacDonald read as a child (Raeper, George MacDonald 33). Young is credited with being an important influence on the Sturm und Drang movement, and on Goethe in particular. ${ }^{12}$ The poems that make up Night Thoughts anticipate MacDonald's conception of the human self oscillating between physical frailty and spiritual strength:

How poor, how rich, how abject, how august, How complicate, how wonderful, is man!

How passing wonder He who made him such!

\footnotetext{
${ }^{12}$ Klopstock wrote a poem upon his death, and he was considered by other German writers to be superior to Milton (Leslie Stephen, Dictionary of National Biography, 1885-1900, Volume 63).
} 
Who centred in our make such strange extremes!

From different natures marvellously mix'd,

Connexion exquisite of distant worlds!

Distinguish'd link in being's endless chain!

Midway from nothing to the Deity!

A beam ethereal, sullied and absorb'd!

Though sullied and dishonour'd, still divine!

Dim miniature of greatness absolute!

An heir of glory! a frail child of dust!

Helpless immortal! insect infinite!

A worm! a god!-I tremble at myself,

And in myself am lost! At home a stranger,

Thought wanders up and down, surprised, aghast,

And wondering at her own: how reason reels!

$\mathrm{O}$ what a miracle to man is man,

Triumphantly distress'd! what joy, what dread!

Alternately transported and alarm'd!

("Life, Death, and Immortality" 68-87, italics mine)

Young's poem, written after the deaths of his wife and step-daughter, also makes the connection between the soul and the mind, a relationship crucial to MacDonald's ideas about the imagination. Young uses the notion of dreaming to describe the movements and processes of the mind, and its connection with "her gross companion," the human body:

While o'er my limbs sleep's soft dominion spread, What though my soul fantastic measures trod O'er fairy fields; or mourn'd along the gloom Of pathless woods; or down the craggy steep Hurl'd headlong, swam with pain the mantled pool; Or scaled the cliff; or danced on hollow winds, With antic shapes, wild natives of the brain?

Her ceaseless flight, though devious, speaks her nature

Of subtler essence than the trodden clod;

Active, aërial, towering, unconfined,

Unfetter'd with her gross companion's fall.

(92-102 italics mine)

As I hope to demonstrate in my first chapter, MacDonald makes the dreaming mind the foundation for his exploration of the distance between the physical and the spiritual in Phantastes, his first novel. The mind and its capacity for dream (among other functions) become the means by which MacDonald reconciles that distance in his fiction.

Friedrich Gottlieb Klopstock’s Der Messias (The Messiah 1748-1773), which MacDonald read in translation, represents the limitations of man as a physical being 
in his relationship with God, bringing standard Christian doctrine into the romantic framework. ${ }^{13}$ The subject of the poem is "the Incarnation": Jesus' descent to earth and consequent adoption of a "human state" as a means of achieving "degenerate man's redemption" through "suffering" (I: 1-3). The poem thus sets up these contrasting ideas of degeneration and redemption. Man's mortal (and physical) state, "wretched" and "deform'd" (152) is thus positioned alongside that which this wretchedness contains: the "sanctuary" (21) of the spirit. The poem represents the two states as potentially joined, in the light of God's plan to "form / Anew in man th' image of deity" (155-6), placing the experience or perception of God as occurring within the human body.

Raeper suggests that MacDonald's interest in the literature of Germany began in his university years, when he spent a term cataloguing a library in the north of Scotland. This was possibly in Thurso Castle, the property of a German scholar, Sir George Sinclair. ${ }^{14}$ In The Portent (1864), the protagonist Duncan Campbell describes the library of the place at which he tutors as containing, "a whole nest of German classics, which seemed to have kept their places undisturbed, in virtue of their unintelligibility [...]. I found in these volumes a mine of wealth inexhaustive" (45). The influence of German literature and philosophy on George MacDonald's writing (as I hope to show in Chapter One) can be seen first and foremost in Phantastes, through the epigraphs that introduce each chapter. This novel, as with a number of MacDonald's other early works, can be read in light of the classic bildungsroman tale of the German tradition - Anodos' journey into Fairy Land results in an exploration of self focussed on development and growth. ${ }^{15}$

The influence of German thought on MacDonald's novels, however, is not limited to the theme of self-development and the genre of the bildungsroman. We have already noted Klopstock's possible influence on MacDonald's division in his fiction between the world of earthly existence and that of a spiritual realm (a division central to Phantastes). As we shall see, Phantastes uses the concept of dreaming as

\footnotetext{
${ }^{13}$ For MacDonald's reading of Klopstock, see Raeper $394 n$.

${ }^{14}$ See Raeper, George MacDonald, Chapter Four ("The Crown of Stone").

${ }^{15}$ While the term bildungsroman itself was not coined until 1819 (in a lecture given by German professor, Karl von Morgenstern), it was the century prior that saw the proliferation of such seemingly autobiographical novels. In defining the bildungsroman, scholar James Hardin (1991) posits the emergence of the genre in Germany in the last third of the eighteenth century (Reflection and Action $\mathrm{x}$ ). The genre's principal concern, Hardin argues, lies with "the spiritual and psychological development of the protagonist," which, as argued in Chapter One of this thesis, is quite explicitly the experience of Anodos in MacDonald's novel.
} 
well as other elements of fantasy to suggest the landscape of the mind as an intermediary between the physical and the spiritual. But even in his realist texts, MacDonald is preoccupied with this relationship. ${ }^{16}$

\section{The inner and the outer: Von Schubert's Die Symbolik des Traumes}

Another important influence is, I would suggest, Die Symbolik des Traumes (The Symbolism of Dreams; 1813), by the philosopher Gotthilf Heinrich von Schubert - a known influence on Hoffman and Jung. Die Symbolik des Traumes sets up a quasiscientific view of the relationship between the earthly and the divine. According to von Schubert, the natural world was once the language in which divine love spoke to the love within man, with the mind acting as the instrument of comprehension. Because man has turned away from the divine towards earthly matter, however, the human mind has been in a so-called "state of madness" (Wahnzustand 140). It has thus started sharing the role of the soul (which, according to von Schubert, has a lower function), even though mind and soul should be distinct. In its madness, von Schubert argues, the mind fails to recognise that peace and truth cannot come from the physical world. It is illumined either by divine inspiration (which takes the form of dream or prophecy), or by having that which is dearest to it in the physical world taken away (141).

Von Schubert uses the distinction between the physical and the spiritual to distinguish his concept of the mind (Geist; "ghost" or "spirit") from that of the soul (Seele): the natural aim of the mind's longing and striving is the divine, while that of what he somewhat confusingly calls the "soul" is the physical and sensual (125). According to von Schubert, the mind was meant to rule over "all things sensual and natural" (das Sinnliche und Natürliche 125), but in its present, earthly existence it is a slave to the sensual world. Schubert identifies two "poles" (Pole 129) of the human nervous system: the cerebral (Cerebralsystem 128) system (the senses and organs of conscious movement) and the ganglion (Gangliensystem 128) system (the organs of the chest and lower body; blood vessels). The ganglion system absorbs physical and earthly nourishment from food and transmits it to the nerves, while the cerebral system absorbs etheric fluid, thus connecting it to the spiritual realm. This etheric fluid, according to Schubert, is constantly renewed "from above" (von oben

\footnotetext{
${ }^{16}$ As evidenced by the recurrence of dream, memory, madness, depression and drug addiction.
} 
her 128), from the "forces/streams of life" (Lebensströme), but becomes periodically paralysed by the physical aspects of our body. This results in sleep, a state allowing the "etheric" (ätherische 128) aspect of our nerves to replenish, and once again gain control over the physical aspects.

The binary relationship of sleeping and waking is thus one of the ways by which von Schubert illustrates his more general principle of the relationship between the spiritual and the physical worlds. It is in our dreams that we can find understanding of those feelings wrongly interpreted as physical. In sleep, the perceptions of the sensual nerves are suspended, and so the sensitivity of the spiritually-connected ganglion system is regained. The experiences of somnambulists attest to the fact that in the state of "animalistic magnetism" (animalischer Magnetismus 133), the principle of the so-called soul is transferred from the head to the heart. The heart, von Schubert argues, is intimately connected with the eye, and is in fact the centre of all our perceptions of the world without (134). But it is the mind that brings its "peculiar, higher life" (eigenthümliches, höheres Leben 139) to such states, differentiating them from the natural instincts of animals.

With regard to the relationship between the inner and outer, von Schubert uses the metaphor of a ship sailing on the ocean to represent the nature of the soul. According to this paradigm our physically-oriented soul operates within larger, universal circumstances: it is influenced by "the outer world" (der äußern Welt des Lebens 2), just as a ship on the ocean depends upon external forces such as the wind and the water. People who have led "an inner life" (ein innerliches Leben 30) are more likely to access prophecy and revelation of God's truth. As has been noted, the inner life finds expression in dream and prophecy, and has its basis in the primordial natural world. Nature was the original means of communication between the divine and Man, and thus the natural world appears as an "embodied dream world, a prophetic language in living, hieroglyphic shapes" (Eine verkörperte Traumwelt, eine prophetische Sprache in lebendigen Hieroglyphengestalten 33). While the natural world thus reflects the inner life, it also functions as a mirror of the divine, the "invisible higher order of things" (der unsichtbaren, höheren Ordnung der Dinge $35)$.

Von Schubert connects, therefore, not two but three "worlds": the external physical world, the inner mental life of the individual, and the realm of the spiritual 
or divine. Somewhat similarly, MacDonald's novels identify as points of interest the intersections of these three planes within the individual subject. The individual is caught between the physical world, and the divine, and for MacDonald the mind (and its processes) is the crucial location in which to explore the possible consequences of such a conflict. In MacDonald, however, the superiority of the spiritual over the physical is tempered by his intense investment in the value of the human physical experience. He avoids an easy binary distinction between the two states by setting value on the interaction occurring at the borders of each. This deconstruction of binary is carried out to a large extent through character: the interaction between the physical and the spiritual forms MacDonald's primary means of approaching the central subject of self.

\section{"A glimpse of something better": spiritual development and the mind}

MacDonald's interest in the mind is intricately bound up with his interest in the attainment of moral perfection through change and development. Both Phantastes and Adela Cathcart situate the spiritual crises of their central characters at a similar point in time: the transition from childhood to adulthood. Anodos has just celebrated his twenty-first birthday, and Adela is presumed to be of a similar age. ${ }^{17}$ Wilfrid Cumbermede, on the other hand, is somewhat different, in that it begins with the protagonist as a young child, and follows his development right through to adulthood. The bildungsroman nature of the novel, however, necessarily makes that point of transition a particularly significant one, and the events of the novel serve to highlight this. The crisis involving the junction of the physical world and that of the spiritual is made explicit in this novel by the temptation of wealth. The bildungsroman tradition, with its focus on the development of the individual towards a realisation of self is thus the primary motivation behind the characterisation of several of MacDonald's novels. Phantastes, Adela Cathcart, Wilfrid Cumbermede, and Malcolm, for example, each focus on the spiritual development of the main protagonist (in four out of five cases the eponymous hero/heroine), the result of which is not only spiritual enlightenment but a stable sense of self. ${ }^{18}$

\footnotetext{
${ }^{17}$ Early on in the novel she is described as having called the narrator 'uncle,' "since ever she had begun to speak, which must have been nearly twenty years ago" (12).

${ }^{18}$ The formation of self of the protagonist of Donal Grant, furthermore, was to a certain extent the subject of the earlier Sir Gibbie (1877).
} 
The interest in the self as a focalising subject, or what critic Nicholas Saul has described as "the systematic exploration of the self in its manifold relationships with inner self, community, nature and God, and the concomitant translation of those abstract findings into practical human fact in the cause of perfection" (and, indeed, the very "thrust of the German Enlightenment," 2-3), derives from the German literary tradition. Responding both to Cartesian rationalism (cogito, ergo sum) and Charles Bonnet's (1720-93) sensibility (je sens, donc je suis), Kant and Herder focused on the human experience of nature highlighting the individual subject as the centre of scrutiny and what Saul has termed, "the agent of reform" (18). The individual certainly becomes such an "agent of reform" in the case of Donal Grant. In the novel, enlightenment as a result of the successful negotiation of the physical and the spiritual comes about in a character other than the protagonist. Donal himself functions not as the subject of such a process, but as the means by which transcendence is attained by another. In comparison with the immoral, drug-addled lord $^{19}$ Morven, he is a character who has already attained moral perfection, capable of reforming and educating others. His physical enforcement of the earl's withdrawal from drugs results in genuine remorse on the part of that character, and, as MacDonald puts it, "a glimpse of something better" (383) after death. The same can be said of Malcolm MacPhail, who functions (in Malcolm) as a moral yardstick by which other characters can be measured. ${ }^{20}$

In The Flight of the Shadow these two modes of thinking about the self merge, as the novel's narrator (as does Wilfrid Cumbermede) moves from childhood to adulthood during the progress of the story. Belorba's development, however, is set against the increasingly fragmented self of her uncle. And while the imminent breakdown of his character serves as a warning for her own burgeoning sense of identity, the novel's focus is not on developing the self, but on healing that which was once whole but has since been broken. While at one level all of MacDonald's novels are novels of "becoming," this approach to character necessarily involves a consideration of the self as a complete entity (a final product as the subject rather than an exploration of that product's development).

\footnotetext{
${ }^{19}$ I have not capitalised the title of "lord" in this instance as MacDonald does not do so in his novel. The same goes for mentions of "lady" Cairnedge in discussion of The Flight of the Shadow.

${ }^{20} \mathrm{His}$ role as an educator is even greater in the novel's sequel, The Marquis of Lossie (1877).
} 


\section{"The mysteries of reality": other influences}

The situating of such processes of development and identity in the mind shows a clear adoption of principles of eighteenth-century German philosophy. The idea of a quest toward spiritual enlightenment, however, is hardly alien to the English literary tradition. Texts such as Spenser's The Faerie Queene (1590), Milton's Samson Agonistes (1671), and Bunyan's Pilgrim's Progress (1678) were also favourites of MacDonald's, and he makes both explicit and implicit connections to them in his fiction. As his writings reveal, however, MacDonald approached religion in an unorthodox fashion. He wrote to his sister-in-law, Charlotte Powell Godwin, in December 1884: "I believe in nothing but Jesus Christ, in whom are all the mysteries of reality" (Sadler 312). MacDonald saw the figure of Christ as central to his religious views, measuring all other doctrine and teaching (including that from the Bible) against this important precept (Fink 59). It was this attitude that led to his leaving his post at the church in Arundel, and turning instead to lecturing and writing. One can see the centrality of Jesus Christ as an important influence on several of his main characters, in particular Malcolm MacPhail and Donal Grant. MacDonald's literary explorations of the self as subject are thus frequently focalised through the mythic characteristics of Christ.

MacDonald's religious eccentricities also derive from his ideas concerning the function of the imagination. He argues against the superiority of rational reasoning over imagination, stating that the "main function" of the latter is "to inquire into what God has made" ( $A$ Dish of Orts 8$)$. Although the imagination is "aroused by facts, is nourished by facts; seeks for higher and yet higher law in those facts," it refuses, MacDonald asserts, "to regard science as the sole interpreter of nature, or the laws of science as the only region of discovery" (8). Discovery is for MacDonald a motivating feature of the human subject. Imagination is "that faculty which gives form to thought - not necessarily uttered form, but form capable of being uttered in shape or in sound, or in any mode upon which the senses can lay hold" (8). It is thus seen as a creative force, but MacDonald warns against the use of the word "creation" as applied to the thought of humans: for him, true creation is possible only for God himself. Man's imagination comes from that of God, just as man himself is made in the image of his maker. 


\section{Chapter One:}

\section{"Self will come to life": the landscape of the mind in Phantastes}

\section{Introduction: between the inner and the outer}

George MacDonald's Phantastes (1858) is a novel about a spiritual coming-of-age through fantasy. On the morning following the celebrations of his "one-andtwentieth birthday" (13), the hero, Anodos, enters the fantasy world of Fairy Land, returning to the world of his 'reality' only in the last chapter. Anodos' experience as one of a journey to self-discovery is reflected in his very name, which comes from the Greek "odos" meaning "the way." Combined with the prefix "an" it comes to mean an ascension or progress upwards; in the allegory of the cave, found in Book VII of The Republic, Plato uses the word to describe man's ascent towards enlightenment (282). However, the word with added prefix can also mean the absence of a way or the "not-way" chosen, which is also significant in terms of the choices that Anodos makes throughout his journey. The events which occur in Fairy Land suggest self discovery, or "becoming," as Anodos encounters characters and situations reflecting his own experience. What we see in the novel, therefore, is the development of an internal landscape, where the realm of the mind, as represented by the protagonist's thoughts and emotions, is given external form through character and place. That the fantasy world is an inner landscape is intimated in a number of important ways - through a focus on the more general nature and function of the mind, an emphasis on perception (as relating to both the senses and to understanding) as mediation, and frequent invocation of the specific elements of dream and memory. These features place the novel within the realm of literary psychology. Furthermore, the novel's later movements toward an illustration of death and the afterlife show MacDonald's associated preoccupation with the concept of the self. Finally, the motif of story-telling is present throughout, lending the novel a reflexive character that invites us to interpret it as a reflection of the narratorprotagonist. 
Several critics have commented on the significance of the nineteenth-century science of psychology to the interpretation of Anodos' experiences in Fairy Land. F. Hal Broome, in particular, in an article entitled "The Scientific Basis of George MacDonald's Dream-Frame" (1990), draws attention to the relationship between Anodos' life in the "real" world, and the dreamlike quality of Fairy Land, noting that "these inner and outer realms" are "bridged by transitional phenomena of which the dream-frame $[\ldots]$ is part" (87). He argues that a "medical understanding of the sensorium and sleep" is crucial to the presentation MacDonald gives us, and that "it was good medical knowledge of Victorian times that there were occasions when one could not tell [the two realms] apart" (95). Edmund Cusick also considers the significance of the dream to Phantastes, but he places it in the context of Jungian psychology and the unconscious. He notes that both MacDonald's fantasy and Jung's psychological theory "are Platonic, in that they postulate a transcendent realm (the spiritual world or the collective unconscious) which can manifest itself in, and affect, the individual psyche" (59). As does Broome, therefore, Cusick focuses on the structure of the novel, and the ways in which it presents that movement between "the inner and the outer" (59). I argue, however, that Broome and Cusick have not done full justice to the intensity of MacDonald's focus in this novel, as the author's concern with the mind and the imagination goes beyond this simple dichotomy of inner and outer. One must look for operations of the mind beyond that initial movement between Anodos' reality and Fairy Land: MacDonald focuses intensely (as we shall see) not only on the transitional moments between the two realms, but on their ongoing, and necessary, interaction.

\section{Phineas Fletcher's The Purple Island; or, The Isle of Man}

The context of an inner landscape is informed by the epigraphs which introduce each chapter of Phantastes, as well as the novel as a whole. These epigraphs are taken from a wide variety of sources, from medieval romance narratives to the poetry of the Romantics and MacDonald's Victorian contemporaries. This range notwithstanding, the epigraphs are consistent in their relevance to the working of the mind and the mind's influence on a sense of self. In the following discussion, therefore, I intend to make similar use of the epigraphic material as a means of shaping and developing an exploration of the text. 
The epigraph for the novel as a whole is a rearrangement of two lines from Phineas Fletcher's poem The Purple Island; or, The Isle of Man (1633): "Phantastes from 'their fount' all shapes deriving, / In new habiliments can quickly dight." ${ }^{21}$ Fletcher's lines describe the personification of Phantastes (a member of the Prince Intellect's court), as well as other functions of the mind and body. In Fletcher's allegorical (quasi-Spenserian) poem, Phantastes is himself an allegorist - he must "clothe thought in new [h]abiliments," giving a readable or interpretable form to the essentially intangible. Anodos' adventures in Fairy Land will demonstrate the main character's thoughts similarly personified and given workable form.

Fletcher's poem uses an anatomical and psychological description of the human body as an allegory for the state under the Stuart monarchy. As critic Mark Bayer notes, Fletcher implies that "the individual body in its intricate complexity is the primary agent of God's grace" (this pattern being "a model for the ideal state," Bayer 267). In The Purple Island, Phantastes is second counsellor of the "Prince Intellect['s]" inner court. He is the instigator of thoughts, ideas and intentions, and "the fount of speedy apprehension / Father of wit, the well of arts, and quick invention" (VI: 46). MacDonald's choice of epigraph (the significance of which is also reflected in the title of his novel), testifies to his concern with the personification of thought. As the features of Fletcher's landscape are metaphors for parts and processes of the human body, so Fairy Land becomes a metaphor for the

${ }^{21}$ The next that in the Castles front is plac't, Phantastes hight; his yeares are fresh and green, His visage old, his face too much defac't With ashes pale, his eyes deep sunken been With often thoughts, and never slackt intention: Yet he the fount of speedy apprehension,

Father of wit, the well of arts, and quick invention.

But in his private thoughts and busy brain Thousand thinne forms, and idle fancies flit; The three-shap't Sphinx, and direfull Harpyes train, Which in the world had never being yet:

Oft dreams of fire and water, loose delight;

And oft arrested by some ghastly sprite,

Nor can he think, nor speak, nor move for great affright.

Phantastes from the first all shapes deriving,

In new [h] abiliments can quickly dight;

Of all materiall and grosse parts depriving,

Fits them unto the noble Princes sight;

Which soon as he hath view'd with searching eye,

He straight commits them to his Treasurie,

Which old Eumnestes keeps, Father of memorie.

(VI: 46-48; italics mine) 
mind. While Phantastes remains just one feature of Fletcher's allegory, however, one inhabitant of a landscape representing not just the mind but the whole human body, for MacDonald the mind is all. The narrator of the novel himself warns his reader of the futility of "trying to account for things in Fairy Land," asking us instead to read his story, "like a child, who, being in a chronic condition of wonder, is surprised at nothing" (33). The explicit nature of the narrator's comment creates tension between such a concept of childlike "wonder" at Anodos' encounters, and an otherwise rational interpretation of them. The consistent focus within the text on the workings of the mind, and the use of similarly themed epigraphs as framing devices, suggest that the two are not necessarily mutually exclusive.

\section{Entering the dream: Shelley's Alastor; or the Spirit of Solitude}

The first chapter of MacDonald's novel takes for its epigraph five lines of Shelley's narrative poem, Alastor; or the Spirit of Solitude (1816). These five lines establish an atmosphere suggestive of sleep and dream:

The undulating woods, and silent well, And rippling rivulet, and evening gloom, Now deepening the dark shades, for speech assuming, Held commune with him; as if he and it Were all that was. (15)

The silence of the scene, together with an invocation of almost hypnotic movement in the "undulating woods" and a "rippling rivulet," works with the visual cues of "evening gloom" and "deepening [...] dark shades" to reflect an attitude of slumber, that half-state between sleeping and waking. The somnial mood established by Shelley in this scene is exploited by MacDonald in his first chapter, as he introduces his protagonist in a similar state.

The transition from Anodos' 'real' world to Fairy Land, at the opening of the novel, is achieved through analogous language, heavy with reference to sleep, dreams, thought and consciousness. Furthermore, the language denotes a movement inward and into darkness, a darkness implicitly connected with the protagonist's lack of knowledge about his family's past and thus himself. The first line of the novel reads, "I awoke one morning with the usual perplexity of mind which accompanies the return of consciousness" (15). From the first sentence we are introduced to the key ideas of the novel: the relationship between sleeping and waking, the notion of 
consciousness, and the part the mind plays in both of these concepts. The first clause, in fact, "I awoke" introduces the subject of differing levels of consciousness, while Anodos' "perplexity of mind," as he awakes, suggests to us the importance of mental states to the story. Finally, the phrase "return to consciousness," introduces the first sense of this process as a journey, one necessitating a "return." The opening chapter continues: "[a]s my thoughts, which a deep and apparently dreamless sleep had dissolved, began again to assume crystalline forms, the strange events of the foregoing night presented themselves anew to my wondering consciousness" (15). Implicit in this sentence is the necessary relationship between thought and consciousness - a relationship which is dissolved by the perhaps "dreamless sleep." The "crystalline forms" assumed by Anodos' thoughts as he wakes from sleep recall immediately the role of Phantastes in Fletcher's poem. Thoughts which were suspended during sleep are now clothed in an appropriate way so as to be "presented" before a "wondering consciousness."

We are told that the celebration of Anodos' coming-of-age the night before the events of the story begin was accompanied by the handing over to Anodos the keys to his father's secretary, a cabinet containing the dead man's personal papers. As Anodos himself claims, his father's "personal history was unknown to [him]" (16). Upon first waking, Anodos recalls the events that occurred as he went to explore what the cabinet held. The setting of Anodos' father's room, in which the "strange events of the foregoing night" occurred, lends greater credence to a reading of the novel's events as internal. As Anodos remembers back, the room is described thus:

as if the darkness had been too long an inmate to be easily expelled, and had dyed with blackness the walls to which, bat-like, it had clung, these tapers served but ill to light up the gloomy hangings, and seemed to throw yet darker shadows into the hollows of the deep-wrought cornice. (15)

The traditional relationship between darkness and mystery is obvious in this description. When he finds the chest which once belonged to his father, and determines to search it for details of his father's mysterious past, he considers the fact that "[p]erhaps, like a geologist, I was about to turn up to the light some of the buried strata of the human world, with its fossil remains charred by passion and petrified by tears. Perhaps I was to learn how my father, whose personal history was 
unknown to me, had woven his web of story" (16). Such thoughts of his father, and consequently of his own identity, are described as the "buried strata of the human world," which he hopes to unearth. The state of the "fossil remains" of his father's life as preserved by emotion, "charred by passion" and "petrified by tears," further reinforces the idea that Anodos is looking for an internal state of being: an understanding of his identity, his psyche.

This essential, inward direction is intimated by the narrative focus on one particular piece of furniture in the room: "all the further portions of the room lay shrouded in a mystery whose deepest folds were gathered around the dark oak cabinet" (15). Having moved into the room and towards the cabinet, Anodos declares, "the door of a little cupboard in the centre especially attracted my interest, as if there lay the secret of this long-hidden world" (16). Already we have the exploration of the room and his father's past described as a "long-hidden world," and the repetitive inward movement is maintained (from the room to the cabinet to the cupboard door) suggesting this world is an inner one. The room is his mind; the darkness his ignorance; and the chest the past that contains the personal history that must be illuminated. When the chest is opened, the past is almost explicitly invoked: the discarded rose-leaves in the corner are "withered," and their "long-lived scent" has "long since departed," while the colour of "a small packet of papers" has "gone with the rose scent" (16). It is from within this chamber of a forgotten past that appears "as though she had just emerged from its depth," Anodos' fairy grandmother, "a tiny woman-form" (16). ${ }^{22}$

Shelley, whose lines have introduced this scene, presents a similarly personified figure of thought, a "spirit" (Shelley 92), which holds "commune" (110) with the poem's protagonist. Alastor, as a narrative poem, recounts the story of a young poet's journey in pursuit of the Ideal, in the process of which he meets the above spirit. Later, his Ideal appears to him in a dream in the form of a "veiled maid" (151), who embodies those "[t]houghts the most dear to him" (160-1). The poet/protagonist goes on to see "two eyes, / Two Starry eyes, hung in the gloom of thought" (489-90), clearly belonging to this female personification of his Ideal, and

\footnotetext{
${ }^{22}$ As the novel is narrated in the first person, the fairy grandmother is the first to speak the protagonist's name. The old crone, whom Anodos meets underground halfway through the story, also calls him by his name, but otherwise he remains an anonymous "I" throughout. The name Anodos, as mentioned earlier, comes from the Greek "odos" meaning "the way," which when combined with the prefix "an" comes to mean to ascend or progress upwards. In the allegory of the cave, found in Book VII of The Republic, Plato uses the word to describe man's ascent towards enlightenment.
} 
aligning her with a figment of his thought. She remains a vision, only reachable through dream, however, and so he pursues her to the point of death and beyond. The dream as a means of conveying the fantastic experience, and as a way of defining the relationship between the protagonist and his image of the Ideal, is central in both texts. The form of the Ideal, furthermore, as a woman, is also significant, aligning the experience with an act of love. And, finally, the idea in Shelley's poem, that this Ideal figure embodies "thoughts the most dear" to the protagonist, is mirrored in MacDonald's text.

The fundamental significance of perception to Shelley's poem, highlighted by the appearance of the "two eyes / Two Starry eyes, hung in the gloom of thought," appears right from the opening chapter of MacDonald's novel, with Anodos' encounter with his fairy grandmother. It is through eye contact that Anodos is first introduced to the concept of Fairy Land. His fairy godmother orders him, "look into my eyes" (18), and the response is immediate:

They filled me with an unknown longing. I remembered somehow that my mother died when I was a baby. I looked deeper and deeper, till they spread around me like seas, and I sank in their waters. I forgot all the rest till I found myself at the window, whose gloomy curtains were withdrawn, and where I stood gazing on a whole heaven of stars, small and sparkling in the moonlight. Below lay a sea, still as death and hoary in the moon, sweeping into bays and around capes and islands, away, away, I knew not whither. (18)

Anodos' attitude of "gazing" in this scene is reinforced by the description of the window at which he stands, with its open curtains, which also suggests open eyes. Looking into his fairy grandmother's eyes, furthermore, has altered Anodos' own vision, and he sees before him not just the surface of her eyes but "a sea, still as death and hoary in the moon," which his grandmother whispers is Fairy Land. This initial vision, the first experience of seeing something that is not "really" there, precedes the actual fantasy journey, and thus invites us to read what follows as an internal journey. This is reinforced, of course, by the invocation of memory, in Anodos' recollection of his mother's death.

Anodos' first vision of Fairy Land, as perceived by looking into his grandmother's eyes, is followed by his awakening the next morning to a bedroom similarly transformed. His memories of the events of the night before are interrupted 
by the sudden awareness of the sound of water running somewhere in his room.

Arising, Anodos finds that his wash basin "was overflowing like a spring; and that a stream of clear water was running over the carpet, all the length of the room, finding its outlet I knew not where" (19). Furthermore, the carpet of the chamber, which Anodos owns to having designed himself, "to imitate a field of grass and daisies," is similarly animated:

[T] he grass-blades and daisies seemed to wave in a tiny breeze that followed the water's flow; while under the rivulet they bent and swayed with every motion of the changeful current, as if they were about to dissolve with it, and, forsaking their fixed form, become fluent as the waters. (19)

The use of words such as "seemed" and "as if" in this context reinforce the ambiguity of the situation. The illusion is continued with the transformation of the dressing-table, "an old-fashioned piece of furniture of black oak, with drawers all down the front $[\ldots]$ elaborately carved in foliage, of which ivy formed the chief part" (19). The intricacy and close detail of the following description is telling:

I happened to fix my eye on a cluster of ivy-leaves. The first of these was evidently the work of the carver; the next looked curious; the third was unmistakeable ivy; and just beyond it a tendril of clematis had twined itself about the gilt handle of one of the drawers. (19)

The initial "fix" of Anodos" "eye" that sets up the scene, identifies perception as the crucial faculty in operation. The following step-by-step transition from reality to the fantasy depicted, reinforces this notion, as it works toward the "unmistakeable" nature of the final product.

\section{Perceiving fantasy, perceiving the soul}

Perception is not only the means of entry in Anodos' interaction with the fantasy of Fairy Land. It surfaces throughout the novel, testifying to the crucial nature of the relationship between inner and outer vision. Henry Sutton's poem “Man” (1848), which serves as the epigraph for the third chapter of Phantastes, defines humanity as human-centred perception:

Man doth usurp all space, 
Stares thee, in rock, bush, river, in the face.

Never yet thine eyes behold a tree;

'Tis no sea thou seést in the sea,

'Tis but a disguised humanity.

To avoid thy fellow, vain thy plan;

All that interests a man, is man.

Like Fletcher's personification of the character Phantastes, Sutton's poem describes the mechanisms of the mind occurring in the context of an externalised world. The poem's speaker describes an external landscape, "rock, bush, river [...] sea," but argues that what we see in this landscape is not in fact nature, but "a disguised humanity" (5). Our thoughts and our perceptions of the external world are irrevocably guided and influenced by our internal landscape. And once again vision is the specific means by which such influence is achieved. It is "thine eyes" to which the speaker of the poem appeals, and, in return, the presence of man in nature "[s]tares thee" back. But perhaps the most interesting line is the central one: "Tis no sea thou seést in the sea" (4). The homonyms "see" and "sea" in this line epitomise the issue at stake: the ambiguity at the heart of what is seen and what is deemed 'reality. ${ }^{23}$

The significance of perception to Anodos' experiences in Fairy Land, and in particular that faculty's importance in negotiating the relationship between the inner world and one's external environment, is maintained with the epigraph to chapter nine. These nine lines come from Coleridge's "Dejection: an Ode" (1802), in which the poet begins by discussing the ways in which a depressed mind, one which suffers from "[a] grief without a pang, void, dark, and drear" (21), influences one's perception of the natural world (in particular its potential to inspire poetry). The distinction is made in the poem between seeing with the senses and with the emotions: the speaker "see[s], not feels" (38) the beauty of the night sky. But most importantly for the speaker in these lines is the despair that arises from the fact that in such a bleak mood he can "gaze forever" (35) on his surroundings and yet "not hope from outward forms to win / The passion and the life, whose fountains are within" (37-8). His inner state of mind prevents any positive interpretation of his surroundings.

\footnotetext{
${ }^{23}$ The ambiguity in Sutton's poem between that seen in the world and in the mind recalls "the mighty world" of Wordsworth's 'Tintern Abbey': "Of eye and ear, both what they half-create, / And what perceive" (106-109). As we shall see, the mind's role in perception is crucial to Anodos' experiences in Fairy Land.
} 
The lines preceding MacDonald's chapter come from later in the poem, as the speaker describes the opposite condition, the positive influence of one's mind on the environment:

Ah! from the soul itself must issue forth, A light, a glory, a fair luminous cloud, Enveloping the Earth -

And from the soul itself must there be sent A sweet and potent voice, of its own birth, Of all sweet sounds the life and element!

(Coleridge 11. 61-66)

The imagery here, of the "fair luminous cloud, / Enveloping the Earth," as a metaphor for the influence of a positive state of mind on one's perception of the world (combined with the opposing dark imagery of the earlier lines, and the special significance of "the soul" in informing this relationship), is central to MacDonald's portrayal of a similar concept, the shadow, though described in opposite terms.

Soon after entering Fairy Land, Anodos comes across a cottage, in which he finds an old woman who is reading about the relationship between light and dark. As she reads aloud to Anodos, stating that "[t]he light doth but hollow a mine out of the infinite extension of the darkness" (62-3), Anodos feels himself compelled to open the door of what appears to be a cupboard in the corner of the room, despite the old woman's explicit warning against doing so. ${ }^{24}$ As he does so, a dark figure breaks out: "All I could tell of its appearance was, that it seemed to be a dark human figure" (64). A personal connection between this dark figure and Anodos himself is immediately established, as the woman goes on to say, "[e]verybody's shadow is ranging up and down looking for him. I believe you call it by a different name in your world: yours has found you, as almost every person's is almost certain to do who looks into that closet" (64). The shadow is a personified part of Anodos' self.

The relevance of Coleridge's poem emerges when, having left the cottage Anodos notices that his shadow is emanating darkness:

These rays of gloom issued from the central shadow as from a black sun, lengthening and shortening with continual change. But wherever a ray struck, that part of earth, or sea, or sky, became void, and desert, and sad to my heart. (66)

\footnotetext{
${ }^{24}$ The scene becomes thus an echo of his early exploration of his father's room: each suggests his experience as a journey of self-discovery.
} 
We can see the light imagery of Coleridge's ideal poetic state, his "fair luminous cloud" accompanied by "a light, a glory," here converted into "a black sun" issuing "rays of gloom" from its "central shadow." The old woman's claim that the shadow is specifically Anodos' imbues it with an intimate connection to the self, recalling Coleridge's light, which "from the soul itself must issue forth" (61 italics mine). Anodos' shadow is playing the same role for MacDonald as Coleridge's dejection, through its negative influence on the external environment. In other words, the shadow is the personification of a state of mind.

The specific effects of the shadow are continued when Anodos meets a beautiful child, around whose head sits "an aureole of emanating rays" (66). As Anodos looks at the child, however, creeping round from behind him comes "the something dark": "the child stood in my shadow. Straightaway he was a commonplace boy" (66). The imagery here, of the "creeping" malevolence of the shadow, is reminiscent of Coleridge's description of dejection as "viper thoughts, that coil around my mind, / Reality's dark dream!" (102-3). The comparison to a serpent is strengthened when Anodos goes on to meet a young girl, and watches as "the shadow glided round and inwrapt the maiden" (68). Both descriptions make use of metaphor and personification to highlight the relationship between a state of mind and the influence it has on one's perception of external surroundings. Coleridge refers to the detrimental force of his negativity as "suspend[ing] what nature gave me at my birth, / My shaping spirit of Imagination" (85-6). The "shaping" element here takes us back to the role of Phantastes in Fletcher's The Purple Island, as the force which gives shape and form to the mind's thoughts.

Mutability of form and its connection to internal states of mind is a recurring feature of Anodos' experience. When he finds himself exploring a particularly grim underground landscape, for example, his surroundings are described in such a way as to manipulate the pathetic fallacy. Like the opening of the novel, the movement in the passage is inward, "descending spirally into its abyss" (209), as if into the self. While exploring these underground caverns, furthermore, he meets an old woman, who teases him by saying that if only he had a beautiful companion, a woman, "how different everything would look" (124). As he looks at her, the woman transforms before - or, rather, in - his eyes, "[a]s a rough unsightly bud might suddenly blossom into the most lovely flower; or rather, as a sunbeam bursts through a shapeless cloud, and transfigures the earth" (124), revealing "a face of resplendent beauty, as it were 
through the unsightly visage of the woman" (124 original italics). At the same time the surroundings change to reflect the transformation of the woman, revealing

A summer sky [...] gray with heat; across a shining slumberous landscape, looked from afar the peaks of snowcapped mountains; and down from a great rock beside me fell a sheet of water mad with its own delight. (124-5)

But the beautiful vision does not last. As Anodos draws away from her, her original appearance returns, accompanied by the enclosed landscape: "[a]gain the infernal laugh grated upon my ears; again the rocks closed in around me, and the ugly woman looked at me with wicked, mocking hazel eyes" (125 italics mine). What can be seen in this passage is the way in which the witch's spell causes a transition in Anodos, which takes him from a state within to one without. His surroundings widen from a dark cave to a summer sky "above," and, to be seen "afar," mountain peaks. But this is immediately revealed to be a false enlightenment, as with the spell's conclusion the landscape once again closes in, just as Anodos returns to his self-contemplation.

While a number of the earlier epigraphs chosen by MacDonald (in particular that from Shelley's Alastor) warn against the dangers of prolonged introspection and argue instead for contemplation of the self in others, here Anodos' attempt to do so is thwarted by the witch. She offers deceit, not truth. Notably, however, it is immediately after this episode that Anodos emerges from the depths of this subterranean landscape to explore once again the surface world of Fairy Land, perhaps in a glimpse of the true enlightenment to come: "I saw, a few yards ahead of me, the long-forgotten daylight shining through a small opening [...]. With great difficulty I accomplished these last few yards, and came forth to the day" (126-7). The experience within the tunnels and the danger of the witch's temptation reflect that concern with self-preoccupation. The beauty offered by the witch is false because of the deceptive circumstances surrounding it. Anodos must return to the upper world in order to pursue his vision of the Ideal.

It is not just visual perception but an enrichment of all the senses that characterises Anodos' experience in Fairy Land. Just after arriving there, for example, he finds upon eating the food that it "not only satisfied my hunger, but operated in such a way upon my senses that I was brought into far more complete relationship with the things around me" (42). This involves not only that "[t]he 
human forms appeared much more dense and defined; more tangibly visible" (42), but also that

I seemed to know better which direction to choose when any doubt arose. I began to feel in some degree what the birds meant in their songs, though I could not express it in words, any more than you can some landscapes. At times, to my surprise, I found myself listening attentively, and as if it were no unusual thing with me, to a conversation between two squirrels or monkeys. (42)

Fairy Land's effect on perception, therefore, is not restricted to sight, but extends to sound and, more importantly, to understanding, in the connection Anodos feels with the songs of the birds. The $O E D$ defines perception in just these terms: "The process of becoming aware or conscious of a thing or things in general; the state of being aware; consciousness; (spiritual) understanding” (“perception” $n$. I. i. a).

\section{Wordsworth's "The Solitary" and an architecture of imagination}

Wordsworth's "The Solitary," an extract of which MacDonald chose as the epigraph to chapter eleven, is from the second book of "The Excursion" (1814), itself intended by the author to be the second part of a longer (and uncompleted) work, The Recluse. The extract used by MacDonald in Phantastes describes a vision by a solitary hermit of a city in the middle of a wild vale:

A wilderness of building, sinking far And self-withdrawn into a wondrous depth, Far sinking into splendour - without end: Fabric it seemed of diamond and of gold, With alabaster domes, and silver spires, And blazing terrace upon terrace, high Uplifted. (Wordsworth, “The Excursion” 11. 836-42)

The vision occurs whilst the hermit is following a search team of shepherds back down the hill, after finding the body of an elderly man who had gone missing. The sight is one of "temple, palace, citadel, and huge / Fantastic pomp of structure without name, / [...] vast in size, in substance glorified" (858-66). The scene is strikingly similar in terms of its magnitude and richness to one in Phantastes, when Anodos catches his first glimpse of the Fairy Palace: 
[O]n a broad lawn [...] stood a stately palace glimmering ghostly in the moonshine: it seemed to be built throughout of the whitest marble. There was no reflection of moonlight from windows - there seemed to be none; so there was no cold glitter; only, as I said, a ghostly shimmer. Numberless shadows tempered the shine, from column and balcony and tower. For everywhere galleries ran along the face of the buildings; wings were extended in many directions; and numberless openings, through which the moonbeams vanished into the interior, and which served both for doors and windows, had their separate balconies in front, communicating with a common gallery that rose on its own pillars. [...] I did not succeed in mastering the inner topography of the building, so extensive and complicated was it. (74)

While Wordsworth's hermit describes what he sees "[i]n vision" (868), saying "[t]hat which I 'saw' was the revealed abode / Of Spirits in beatitude," MacDonald takes the notion one step further and invests his "vision" with actual reality for his protagonist. However, Anodos' insistence on the building's "ghostly shimmer," repeated as it is within the passage, gives it more of a sense of a supernatural vision. The hermit describes the building in his vision as "a wilderness," suggestive of a rambling size. MacDonald too conveys a sense of great scale with the repetition of plurals: "galleries," "wings," and "numberless openings," while the "inner topography" is similarly "extensive and complicated." For Wordsworth's solitary hermit, the "apparition fade[s] not away" (880), but he turns away from it to return back down the mountain to his home. For Anodos, the palace also remains in sight, but, in contrast with Wordsworth's hermit, he not only directly approaches the building, but enters inside it. The palace thus becomes a present object in the 'reality' of the fantasy world.

Within, however, there is more evidence for the building and the surrounding landscape as symbols of Anodos' mind. Entering the palace, Anodos comes across a door with his name appearing on it in silver letters. To his surprise the room behind this door is an exact replica of that which he has left behind in his "reality":

[T] he room was in every respect a copy of my own room, the room whence the little stream from my basin had led me into Fairy Land. There was the very carpet of grass and moss and daisies, which I had myself designed. $(76)^{25}$

\footnotetext{
${ }^{25}$ This scene is surely the source for that in Jim Henson's 1986 fantasy film, Labyrinth, in which the heroine, Sarah, finds just such a replica of her own bedroom within the fantasy world itself.
} 
The replication of his chamber, the site from which Anodos made the initial transition to the fantasy landscape, and the repeated insistence on the carpet as that "which I had myself designed," suggests the value the palace has for being, like Wordsworth's "wilderness of building," a feat of individual vision. The specific replication of Anodos' room here within the fantasy landscape, locates it as occurring within the mind of the protagonist.

Anodos' movements through the halls of the Fairy Palace are similarly worded to emphasise the architecture within which he walks as that forming an inner world: "I walked through the red glimmer of the silent hall; but lonely as there I walked, as lonely trod my soul up and down the halls of my brain" (115). Anodos goes on to label the room in which he once again discovers the white lady, where she is just one of a number of statues, "the white hall of Phantasy" (114).

The inward movement and increasing darkness of the opening chapter, which signal a movement into the world of thought, also define the setting in chapter seventeen, as Anodos, by this stage well-ensconced in the fantasy world, finds himself entering a new and more barren landscape. From here he descends into a hole-like cave, described as "a roughly excavated well, only very large. I could perceive no bottom; and it was not till the sun actually rose, that I discovered a sort of natural staircase, in many parts little more than suggested, which led round and round the gulf, descending spirally into its abyss" (121). At the bottom of the stair is a passage, following which Anodos enters deeper and deeper into the subterranean world:

Wider and loftier grew the way; new paths branched off on every side; great open halls appeared; till at last I found myself wandering on through an underground country, in which the sky was of rock, and instead of trees and flowers, there were only fantastic rocks and stones. And ever as I went, darker grew my thoughts, till at last I had no hope whatever of finding the white lady. (121)

Anodos' movement is accompanied by his ever-increasing negative "dark" thoughts, made more poignant by the necessarily inward direction of his journey. The external landscape acts through the pathetic fallacy as a reflection of our protagonist's internal experience. This aspect of the novel continues in the ambiguous wording of the following passage: "A gray mist continually gathered behind me. When I looked 
back towards the past, this mist was the medium through which my eyes had to strain for a vision of what had gone by; and the form of the white lady had receded into an unknown region" (126). Anodos' wandering in an obscure mist can quite easily be read as a mental "fogginess." Looking towards the past, as Anodos does in this passage, can be interpreted as literally looking back at the way he has been, but also as remembering what has gone before. Similarly, "vision" can be defined as what is actually seen, but also as the mental visualisation of what has been seen in the past. The "unknown region" to which the white lady has vanished can also be read as an actual place in Fairy Land, but the verb "receded" as used here seems to suggest rather the movement of a thought or memory out of consciousness.

While wandering below ground, Anodos considers "that my imagination filled my whole soul with the play of its own multitudinous colours and harmonies around the form which yet stood, a gracious marble radiance, in the midst of its white hall of phantasy" (126, original italics). As in the description of Anodos wandering through the halls of the Fairy Palace, MacDonald once again attributes to the imagination its own "hall of phantasy." Recalling as it does Fletcher's character, a reading of the architectural setting of the novel as symbolic of a mental landscape is strengthened.

\section{Chasing the dream: Beddoes" "Pygmalion" and Heine's "Erklärung"}

As was discussed with reference to Shelley's Alastor, the states of sleeping and dreaming are crucial to Anodos' transition into the world of Fairy Land. Dreaming recurs frequently within the fantasy world itself, becoming especially significant in Anodos' initial discovery (and later pursuit), of the marble lady. Soon after entering Fairy Land Anodos discovers a cave, and throws himself down "on a mossy mound that lay like a couch along the inner end" (43). He lies in what is described as "a delicious reverie," while "all lovely forms, and colours, and sounds seemed to use [his] brain as a common hall, where they could come and go, unbidden and unexcused" (43). In similar terms to the initial transition described above, in which the interior of his bedchamber was transformed into a forest, Anodos becomes "aware" of a "strange, time-worn bas-relief on the rock opposite" (43). This soon appears to him to represent the figures of the artist, Pygmalion, and the statue of Galatea, "about to step from its pedestal and embrace the man" (43). Anodos defines 
the artist's act of sculpture as an attempt to "mould into a visible body the thought already clothed with form in the unseen hall of the sculptor's brain" (44). As well as reflecting Shelley's embodiment of "thoughts the most dear," this description also recalls the figure of Phantastes in the intellectual hall of Fletcher's poem, whose express role involves the act of clothing thought with form. What Anodos then sees before him in the figure of the marble woman is "more near the face that had been born with me in my soul, than anything I had seen before in nature or art" (44-5). The Ideal for MacDonald is depicted as a part of the self, "born" in the soul of the individual. $^{26}$

The epigraph introducing this chapter comes from Thomas Beddoes' version of the myth, "Pygmalion, or The Cyprian Statuary" (1825), and the lines MacDonald chooses emphasise the significance of the relationship between the state of the statue and sleep:

And [Galatea] was smooth and full, as if one gush

Of life had washed her, or as if a sleep

Lay on her eyelid, easier to sweep

Than bee from daisy.

(Beddoes 11. 128-130)

Like Pygmalion, Anodos takes a knife and recovers the statue from its moss coating: "She lay on one side, with her hand under her cheek, and her face towards me; but her hair had fallen partly over her face, so that I could not see the expression of the whole" (44). ${ }^{27}$ Recalling myths of enchanted sleep such as "the Sleeping Beauty in the Wood," Anodos ponders over "how to awake her" (45). Thinking of Orpheus and his lyre he decides to sing, under the impression that "[m]ight not a song awake this form, that the glory of motion might for a time displace the loveliness of rest" (45). The subject of his song moves along a similar vein, invoking in each stanza the transition from sleep to awakening, and in particular the act of dreaming. He claims that "[s]weeter dreams are in the forest" (47), while

[...] if still thou choosest rather

Marble, be its spell on me;

Let thy slumber round me gather,

\footnotetext{
${ }^{26}$ The relationship between Anodos and his marble lady as depicted in these terms clearly reflects Jung's theory of the anima.

${ }^{27}$ The importance of the act of sleeping to MacDonald's vision of the white lady here comes even at the expense of his earlier description of the statue, when she was "about to step from [her] pedestal and embrace the man" (43).
} 
Let another dream with thee! (47)

The relationship between Anodos and his Ideal, that is the marble woman, is thus defined through the context of sleep and dream. At this time they exist in two separate planes of existence, and Anodos' wish is that they might occupy the same one - whether in consciousness or in dream. ${ }^{28}$ The subsequent awakening (and escape) of the statue informs much of the remainder of the novel, as Anodos searches for what he assumes to be his soul mate.

While characterising thus their initial relationship, the act of dreaming is also offered by Anodos himself as an interpretation of the events that follow. After losing sight of the marble lady, and succumbing to the evil enchantment of the Alder maiden, Anodos considers that all that has previously occurred has been nothing but "the wandering dream of a diseased imagination, operating on a too mobile frame, not merely causing me indeed to travel, but peopling for me with vague phantoms the regions through which my actual steps had led me" (57). The narrator's interpretation of his own experience as (possibly) delusion invites the reader to analyse the whole novel accordingly. As does his earlier warning against reading too deeply into the events of the story, the raising of this issue, and its near-instantaneous dismissal, only raises the reader's awareness of this interpretive possibility.

The idea of a "diseased imagination" as the fuel for Anodos' journey through the fantasy world develops (with the help of continued metaphors of sleep) from connotations of fever into the calm of oblivion, or even death. Floating down the river towards the Fairy Palace (in a manner similar to his later boat journey described above), Anodos finds himself again sleeping, this time "as I had not slept for months" (72). His entire journey down the river is depicted in terms of sleeping and waking: "while I slept, the sun slept not, but went round his arched way. When I awoke, he slept in the waters, and I went on my silent path beneath a round silvery moon" (72). Not only is Anodos defined here in these terms, but so too is his environment:

The sleeping woods, in undefined massiveness; the water that flowed in its sleep; and, above all, the enchantress moon, which had cast them all, with her pale eye, into the charmed slumber, sank into my soul, and I felt as if I had died in a dream, and should never more awake. (73)

\footnotetext{
${ }^{28}$ This relationship is repeated in the story of Cosmo, which Anodos reads while in the Fairy Palace, and will be discussed shortly.
} 
And, in similar fashion to previous instances, this state of slumber is interrupted by a vision, as Anodos is "partly aroused by a glimmering of white" (73), the Fairy Palace.

When Anodos enters the Fairy Palace, he discovers a library. Reading the books results in an experience akin to dreaming:

Mine was the whole story. For I took the place of the character who was most like myself, and his story was mine; until, grown weary with the life of years condensed in an hour, or arrived at my deathbed, or the end of the volume, I would awake, with a sudden bewilderment, to the consciousness of my present life, recognising the walls and roof around me, and finding I joyed or sorrowed only in a book. (81-2 italics mine)

The experience is associated with sleep and dreaming, and the return to consciousness significantly echoes the opening lines of Phantastes itself, with "sudden bewilderment" characterising each transition made by Anodos ("bewilderment" here recalling the earlier "perplexity of mind" experienced at his initial awakening).

One of the stories read by Anodos proves of particular interest to the discussion of dreams in the novel: that of Cosmo and the mysterious woman in the mirror. In this story, the hero (whose place is occupied by Anodos in the manner described above) is a young student, Cosmo, who buys an ancient and curiously carved mirror from a pawn shop in the back streets of Prague. After hanging it on his wall and attempting to discover "some index to the intention of the carver" (94), he sees the figure of a woman enter into the room of the mirror's reflection, lie down on the couch, and fall asleep. When he turns to the actual room behind him, however, she is nowhere to be seen: she exists only in the world of the mirror. It turns out that the woman is a real person living in the city of Prague, but that she is under an enchantment, one which causes her to fall into a state of unconsciousness, during which she has visions. It is during these episodes that she appears in Cosmo's mirror. As Cosmo watches the sleeping woman, mesmerised by her beauty, "a fascinating repose seemed to pass contagiously from her to him as he gazed upon her; and he started as if from a dream, when the lady moved" (97). The similarities between this situation and those fairy tales already mentioned with reference to 
Anodos and the marble lady are clear. When the perspective of the story changes to the omniscient, and we are informed of the condition of the woman who appears to Cosmo in the mirror, it is depicted in the following terms:

In a lofty, silent chamber, in another part of the city, lay a form more like marble than a living woman. The loveliness of death seemed frozen upon her face, for her lips were rigid, and her eyelids closed. Her long white hands were crossed over her breast, and no breathing disturbed their repose. $(106-7)$

The ladies who watch over her talk of the "visions" she has while in these trances, which equate with the times that she appears to Cosmo in his mirror.

The use of sleep and dream to define the relationship between these two characters is significant. When Cosmo at last manages to break the mirror and destroy the enchantment, he dies, with the message that "two souls, loving each other and longing to come nearer, do, after all, but behold each other as in a glass darkly" (89). ${ }^{29}$ MacDonald is using the ontological potential of the dream as a means of exploring the relationship between individuals. The story, through Anodos' significant involvement in it as he takes the place of the protagonist, informs the overall novel and the importance it places upon dreams as a valid means of experience. Thus, while the figure of the woman can easily be read simply as a figment of the imagination, MacDonald imbues the situation and his character with such a developed sense of reality, that she is given "life" of her own, including real physicality as when she becomes "drenched with rain" (107). The story, furthermore, occurs right in the centre of that wider one detailing Anodos' adventures, thus serving as a microcosm for the novel as whole.

It is after reading this story of Cosmo and the woman in the mirror that Anodos once again comes across the marble lady, once again a statue in what has already been described as "the white hall of Phantasy" (114). Recalling Orpheus and his lyre, Anodos awakens her with a song. When he reaches out to touch her, however, she flees from him, and his subsequent pursuit of her takes him out of the Fairy Palace and beneath the ground to the subterranean chambers already described. When he emerges once more, his sombre mood at the loss of the white lady emerges

\footnotetext{
${ }^{29}$ This phrase comes of course from 1 Corinthians 13:12: "For now we see through a glass, darkly; but then face to face," comparing our relationship with God on earth with what it will be in heaven after our deaths.
} 
with him, and his depression is only cured by yet another dream sequence in a world already defined by that act.

The epigraph to the chapter in which Anodos returns to the upper world comes from a song written by nineteenth-century German poet and essayist Heinrich Heine. The song's title, "Erklärung," means "declaration," and the song itself describes a homesick poet, thinking about his love, Agnes. The lines chosen by MacDonald for his epigraph depict the way in which the poet's thoughts of his love lead to his perception of her "[i]n the wind's uproar, the sea's raging grim / And the sighs that are born in him" (125). Once again, thought influences the individual's perception of his environment. Emerging from underground, Anodos finds himself on a grey windswept beach, similar in its wild setting to the shoreline described by Heine: " $[t]$ here was nothing for the eye but mingling shades of gray; nothing for the ear but the rush of the coming, the roar of the breaking, and the moan of the retreating wave" (127). Furthermore, Anodos describes himself as wandering up and down, "a human imbodiment[sic] of the nature around me" (127).

Anodos' actions at this point approach the suicidal: "I stood one moment and gazed into the heaving abyss beneath me; then plunged headlong into the mounting wave below. [...] I sank far into the waters, and sought not to return" (127-8). But, instead of drowning, "[t]he waters of themselves lifted me, as with loving arms, to the surface. I breathed again, but did not unclose my eyes" (128). Once again the experience is described in terms resonant of sleep and dream. The parallels with sleep are maintained as, finding himself alongside a small boat, he gets in and lies down, drawing over him "a rich, heavy, purple cloth" (128). ${ }^{30}$ Closing his eyes, he then imagines the world beneath the surface of the water, that "strange rocks and forests of sea-plants beguiled my eye, sufficiently to be transformed, by the magic of the phantasy, into well-known objects and regions" (128-9). Falling asleep, Anodos has "dreams of unspeakable joy" (224), passing thus "through this wondrous twilight" (225). The effect of the scene is of sleep within sleep, dream within dream.

\footnotetext{
${ }^{30}$ Anodos' actions here again recall Shelley's Alastor, in which the hero, experiencing similar despair, seeks death and takes to the sea in a boat:

A little shallop floating near the shore

Caught the impatient wandering of his gaze.

[...]

A restless impulse urged him to embark

And meet lone Death on the drear ocean's waste

(299-305)
} 
The emphasis placed on the unconscious state when Anodos first entered Fairy Land is doubled by his now falling asleep in what is already a dream world.

\section{"It walketh, in whiteness, the halls of the heart": remembering the self}

The discussion so far has focussed on the importance of the dreaming mind to Anodos' experience of Fairy Land. Not long after Anodos enters the fantasy landscape, however, he laments, "Alas! I brought nothing with me out of Fairy Land, but memories - memories" (40). While Anodos is speaking here of memories of Fairy Land itself brought back to his 'real' world, the opposite is also true: his existing memories of people and events in that 'real' world inform much of his fantastic experience. As described above, when Anodos despairs of ever again finding the marble lady, he commits what equates essentially to suicide, jumping into the sea and seeking "not to return" (128). The experience is connected back to his initial meeting with his fairy grandmother through its association with "the kiss of the mother" (128). Then, looking into his grandmother's eyes, he had "remembered somehow that my mother died when I was a baby" (18). Both incidents rely on the memory of Anodos' childhood relationship with his mother to achieve their emotional impact. As Anodos floats in the waves, presumably waiting to drown, memory is presented as a landscape over which he floats: "vaguely revealed beneath the wave, I floated above my whole Past. The fields of my childhood flitted by; the halls of my youthful labours" (128). The invocation of actual physical space to define mental experience, including memory, is central to the imagery throughout the novel, and provides the main impetus for the reading of its events as symbolic of a mindscape.

In chapter nineteen the faculty of memory comes to the fore, and becomes more specifically associated with defining a sense of self. Just as the Fairy Palace can be read as an architectural representation of the imagination, in this chapter memory too is conceived of as a physical structure. Anodos disembarks from his boat to find himself on an island. His reaction highlights the connection between the processes of the mind and his physical environment, as "a sense of persistent calm and fullness arose in the mind at the sight of the slow, pulse-like rise and fall of the deep, clear, unrippled waters against the bank" (129-30). The waves' motion as "pulse-like" reflects the influence of Fletcher's poem, as the landscape is seen to 
echo the processes not only of Anodos' mind but of his body also. In the centre of the island stands a cottage, inhabited (once again) by an old woman, and providing a place of refuge for the protagonist amidst the conflicts of his journey. This cottage, however, is distinct from those earlier visited by Anodos, in that it serves as a portal through which Anodos can access his past. Two of the four doors found in the cottage lead into the memory of a significant moment in Anodos' life (while a third reveals a vision rather than a memory, and Anodos cannot remember what he found behind the fourth). The doors are each given a name by the woman who acts as their gatekeeper: the Door of Tears, the Door of Sighs, the Door of Dismay, and the Door of the Timeless. The first door explored by Anodos is the Door of Tears, which leads to a memory of his brother's childhood death: ${ }^{31}$

I opened the door, and stepped out. The moment my foot touched the smooth sward, I seemed to issue from the door of an old barn on my father's estate, where, in the hot afternoons, I used to go and lie amongst the straw, and read. It seemed to me now that I had been asleep there. (137)

Once again it is through a comparison with sleep and dream that the movement between states is made, and the repetition of the verb "seemed" works to blur the double-layered boundary between the story's reality and its fantasy. Anodos' movement through the door of the cottage and into his own memory, equates to his initial transition in the novel's first chapter from his bed-chamber to the woods of Fairy Land, but in this case the connecting psychic phenomena is memory rather than dream: "Amidst the horror of the moment, a strange conviction flashed across my mind, that I had gone through the very same once before" (137-8). The memory of his brother's death (by drowning, significantly ${ }^{32}$ ) is painful for Anodos to reexperience, and, returning to the cottage of the old woman, again through the door of the barn, she comforts him with words assuring him of the immortalising power of memory:

Form with its brightness, From eyes will depart: It walketh in whiteness,

\footnotetext{
${ }^{31}$ Death, or the memory of death, is thus a defining feature of Anodos' experience in Fairy Land. It is the memory of his father, mother, and now brother that propels him to action in his search for a sense of self.

32 The connection has already been made between the significance of water and Anodos' experiences in Fairy Land.
} 
The halls of the heart. (138)

While these lines imply the power of memory to not only outlive actual perception but to guarantee the eternity of the soul after death, they also recall the figure of the white lady, "walking in whiteness" (her marble form) in the halls of the Fairy Palace. The connection reinforces the reading of the novel as an exploration of the "halls" of the mind, using physical space and architecture to symbolise a mental process, in this case the accommodation of loss.

The second door which Anodos tries, the Door of Sighs, is more a vision than a memory, and, like Scrooge accompanying "the Ghost of Christmas Past" in Dickens' A Christmas Carol (1843), he can only observe rather than actively participate as he has previously done. The vision is of the white lady and a knight, one whom Anodos has already previously met in Fairy Land. Despite the fact that what Anodos sees is not a memory, the relationship established between the knight and Anodos himself maintains the idea that what Anodos' is accessing through the doors of the cottage is some sort of self knowledge. We are made aware of the fact that Anodos is merely an observer of the scene by the fact that, "A mirror was near me, but I saw that my form had no place within its depth" (138). Anodos cannot see himself reflected in the mirror; the inference is, therefore, that he is not physically present in the scene. When the knight comes closer, however, Anodos finds that, "strange to tell, though the mirror reflected not my form, I saw a dim shadow of myself in the shining steel" (139). The fact that it is in the knight's armour that Anodos sees himself is significant in that at their previous meeting it had been soiled and rusted (48-9), whereas now it shines "like polished glass." The knight becomes thus the personification of Anodos' ideal self, accessible only through vision.

The reflection, described as a "dim shadow of myself," recalls of course the shadow which Anodos earlier brought out of another door. While this shadow served as a negative portrayal of Anodos' inner self, his pride and selfishness, destroying his ability to perceive beauty in his surroundings, the knight of the shining armour represents an ideal or potential self, reinforced by his status as the "beloved" of the white lady (139). Anodos' vision of them together speaks to the nearness of his goal of self-realisation; however, the very fact that it is a vision also suggests distance, as did the mirror in defining the relationship between Cosmo and the woman he could see only in its reflection. 


\section{"No one has my form but the I": forms of the self}

The epigraph introducing chapter twenty two of Phantastes comes from German writer Jean Paul's Titan: A Romance (1803). That work's message of the dangers of self-contemplation is firmly addressed in the second half of MacDonald's novel. After helping two brothers defeat a trio of giants, during which the brothers and giants are all killed, Anodos finds himself confronting another knight, one who can also be read as a of personification his own pride at his success in battle:

[A]pproaching me from the left, through the trees, I espied a resplendent knight, of mighty size, whose armour seemed to shine of itself, without the sun. When he drew near, I was astonished to see that this armour was like my own; nay, I could trace, line for line, the correspondence of the inlaid silver to the device on my own. His horse, too, was like mine in colour, form, and motion; save that, like his rider, he was greater and fiercer than his counterpart. (159)

The resemblance between Anodos and the knight is noticeable in the similarity of their armour, traceable "line for line," and even in their horses, reinforcing the idea that the knight is in some way a projection of our protagonist. The actions of the giant knight, furthermore, strengthen this reading. When Anodos asks to be let past, the knight challenges him, and Anodos is too afraid to fight. When he is then commanded to follow, he obeys, "abashed and stupefied":

How long he led, and how long I followed, I cannot tell. "I never knew misery before," I said to myself. "Would that I had at least struck him, and had had my death-blow in return! Why, then, do I not call him to wheel and defend himself? Alas! I know not why, but I cannot. One look from him would cow me like a beaten hound." I followed, and was silent. (159-60)

The compulsion to simply follow reflects a similar lack of control over his actions that was seen earlier in letting his shadow out of the cupboard. That moment too was defined by an unknown force, an "irresistible desire," drawing him to the conclusion that he "must open that door, and see what was beyond it" (63). His curiosity drew him forward then, as does the knight.

The inability to do anything other despite a lack of overt external pressure suggests instead an internal force, a battle with the self. This was suggested earlier by the old woman's connection of the shadow with Anodos' self: "It is only your 
shadow that has found you" (64 italics mine), the repeated pronoun reinforcing the connection. Anodos reflects on the shadow and the giant knight's similarity, with "a terrible conviction that the knight and [the shadow] were one" (160). The giant knight's symbolic value is strengthened when he shuts Anodos up in a tower, demanding that he, "enter, and take [his] companion with [him]" (160). By "companion" he means Anodos' shadow, which has been his companion the entire way. Again, Anodos obeys without question and finds himself "in pitiful plight" and "listless wretchedness" (160). After a couple of nights spent in this state, however, he hears a voice singing outside, bidding him, "From the narrow desert, $\mathrm{O}$ man of pride,/ Come into the house, so high and wide" (163). He then opens the door, wondering "why had I not done so before?" The words of the song describe Anodos as a "man of pride." The contradicting spatial terms, "narrow desert" and the "house, so high and wide" are used to distinguish between the dangers or narrowness of the self and the world external to the self. The confusion between inner and outer is also significant. The song instructs Anodos to come "into" the house, which ironically means coming out of the tower. The tower, therefore, and the knight who trapped him within it, are joint symbols of the crippling nature of self-pride.

Browning's “Childe Roland to the Dark Tower Came," published in 1855 (just three years before Phantastes), is relevant here. Browning's own account of his poem's composition reveals its relevance to MacDonald's novel (and our discussion so far). The poet posits that he was "conscious of no allegorical intention" in writing "Childe Roland" (Collins and Rundle 336 italics mine). Rather, it came upon him "as a kind of dream," and the result he considered "only fantasy" (336). Having a basis in dream, Roland's quest can be read as akin to Anodos' own: a journey into the psyche.

One of the final stanzas of Browning's poem is particularly relevant as a comparison with Anodos' experience trapped in the tower of his self-pride. Roland, as he approaches that tower symbolic of his own self (the "Dark Tower" of the poem's title), is confronted by "hills, like giants at a hunting [...] / Chin upon hand, to see the game at bay" (190-1 italics mine). Browning's giants are spectators of Roland's confrontation with the Dark Tower, rather than adversaries. Their urging on to "[n]ow stab and end the creature - to the heft!" (192), however, is ambiguous in its addressee (whether it be Roland or the tower itself), and nevertheless reflects 
the violence of Anodos' confrontation with his own giant: in that battle he stabs him, "right through to the armour of his back" (155).

The fact that it is a knight who leads Anodos into the tower is also significant as it is a band of knights that Browning's speaker is following. He describes his journey to the "Dark Tower," as being in the footsteps of "'The Band' - to wit, / The knights who to the Dark Tower's search addressed / Their steps" (39-41). Anodos, too, sees himself as following in the footsteps of other figures of greatness: "I rejoiced, and counted myself amongst the glorious knights of old" (159). The conclusion of Browning's poem is of course the attainment of the speaker's goal, reaching the Dark Tower, but instead of success he sees only failure in the "dying sunset" (189). The Tower itself, furthermore, is described as being as "blind as the fool's heart" (182), revealing further its symbolic value as a form of the self (Roland himself presumably being the fool), in comparison to that which encloses Anodos.

Reaching the Dark Tower is conveyed by Browning as like a trap: "a click / As when a trap shuts - you're inside the den" (173-4). This is reflected in Anodos' fear that he too is trapped in the tower, feeling as he does "in pitiful plight" (160). But, while Browning's poem ends on a sombre note, with the other knights lined up "to see the last of [Roland]" (200), MacDonald chooses to see the potential doom of the tower as merely a challenge: the death of one self is simply the birth of a new one. After emerging from the tower and learning that "it was not [himself], but only [his] shadow, that [he] had lost" (165), a moment of contemplation reveals to Anodos a new beginning:

Another self seemed to arise, like a white spirit from a dead man, from the dumb and trampled self of the past. Doubtless, this self must again die and be buried, and again, from its tomb, spring a winged child; but of this my history as yet bears not the record. Self will come to life even in the slaying of self; but there is ever something deeper and stronger than it, which will emerge at last from the unknown abysses of the soul [...]. (165 italics mine)

While Browning's ends with a "[d]auntless" despair, the result of this incident with the giant knight is just one of a series of "births" of a new self for Anodos.

The tower is clearly not the only symbol of self with which Anodos is confronted in his journey through Fairy Land. As we have seen through the examples of the white lady, the shadow, and the giant knight, MacDonald's concern 
with the self and with identity in the novel lies frequently in the contrasts made between the human and the non-human. Using creatures which are significantly not human, places emphasis on what it is or means to be human. The sentiment behind the epigraph from Jean Paul's Titan, that "No one has my form but the I," reinforces this notion (158). The first such creature that Anodos meets is the vampire-like Ash tree:

It caused a new sensation. Just as one cannot translate a horrible odour, or a ghastly pain, or a fearful sound, into words, so I cannot describe this new form of awful hideousness. I can only try to describe something that is not it, but seems somewhat parallel to it; or at least suggested by it. It reminded me of what I had heard of vampires; for the face resembled that of a corpse more than anything else I can think of; especially when I conceive such a face in motion, but not suggesting life as the source of the motion. The features were rather handsome than otherwise, except the mouth which had scarcely a curve in it. The lips were of equal thickness; but the thickness was not at all remarkable, even though they looked slightly swollen. They seemed fixedly open, but were not wide apart. [...] But the most awful of the features were the eyes. They were alive, yet not with life. They seemed lighted up with an infinite greed. A gnawing voracity, which devoured the devourer, seemed to be the indwelling and propelling power of the whole ghostly apparition. $(36-7)^{33}$

The description is full of near-contradictory statements. The Ash tree is both like and unlike something recognisable from Anodos' own world, but the significance of the differences equates to the notion that it, like its eyes, is "alive, yet not with life." The crucial relationship that the Ash (and in fact all trees within the fantasy landscape) has with the 'real' world is cemented by the words of the beech maiden, another dryad, who rescues Anodos from the Ash. She maintains that all trees hope to one day become human, but that the Ash "has a hole in his heart," and that "he is always trying to fill it up, but he cannot. That must be what he wanted you for. I wonder if he will ever be a man" (39). The relationship between the Ash and Anodos in terms of the self is one of a continuum. The grotesqueness of the tree, as well as its incompleteness (having "a hole in his heart" that he is "always trying to fill") stands in as a potential fate for Anodos himself. He too is lacking something "in his heart," and the danger is that he may become like the Ash. In his lack of a stable sense of

\footnotetext{
${ }^{33}$ The description of the Ash is very like that of the degenerate in MacDonald's later novel, Donal Grant, which will be discussed (in light of Mary Shelley's Frankenstein) in Chapter Five.
} 
self (the motivation behind his quest), furthermore, Anodos is also vulnerable to the predation of creatures such as the Ash, who wish to use him for their own gain.

When Anodos first arrives in Fairy Land, he considers this basic difference between himself and the creatures which inhabit this fantasy landscape:

I, being a man and a child of the day, felt some anxiety as to how I should fare among the elves and other children of the night who wake when mortals dream, and find their common life in those wondrous hours that flow noiselessly over the moveless death-like forms of men and women and children, lying strewn and parted beneath the weight of the heavy waves of night, which flow on and beat them down, and hold them drowned and senseless, until the ebbtide comes, and the waves sink away, back into the ocean of the dark. (21-2)

His anxiety in this scene reflects the distancing inherent in his initial crisis of selfidentity. The sense of difference Anodos feels between himself and the inhabitants of Fairy Land (when they are in fact part of his self) is what is resolved by the end of the novel, in such scenes as that with the tower. The emphasis in the above description of the difference between Anodos and the creatures of Fairy Land as akin to that between night and day, furthermore, recalls the central concern the novel has with the dream state. What it also achieves, however, is a highlighting of the connection that the concept of the night holds with that of death. The intense nature of the description of the sleeping bodies as "moveless death-like forms," held "drowned and senseless" by a state of sleep reinforces the traditional concept of sleep as "death's counterfeit" (Shakespeare, Macbeth 2.3.).

\section{Breaking "the mirror of sleep": dreaming the afterlife}

We have already noted the explicit parallels drawn in the story of Cosmo between the sleeping woman in the mirror and the appearance of death, but the epigraphs and the later events of the novel draw a more intimate connection. For example, the second epigraph heading chapter eighteen of the novel is derived from Jean Paul's Hesperus:

From dreams of bliss shall men awake

One day, but not to weep:

The dreams remain; they only break 
The mirror of the sleep. $(218)^{34}$

Dream is closely associated with the afterlife: the common inversion is made between awakening and death, with dreams providing the connection between levels of existence. The use of the mirror in the extract seems to speak directly to the story of Cosmo read by Anodos in the Fairy Palace, and the release from enchantment through the breaking of the "mirror of the sleep." In that story, however, complete happiness is prevented by the impossibility of two souls meeting within the same plane of existence. This obstacle to their relationship is reflected in Anodos' vain pursuit of the marble lady. Only in the afterlife is such unity of self truly possible

The epigraph to chapter twenty five of Phantastes (the final chapter) is also significant in this context. It comes from the early German Romantic writer and philosopher, Novalis, who is generally thought to be MacDonald's chief literary influence: "Our life is no dream; but it ought to become one, and perhaps will" (180). ${ }^{35}$ The positioning of this at the close of a novel about a fantasy journey is significant, because it points to the future. Furthermore, the events within the final chapter forge a final link between Anodos' experience in Fairy Land and the experience of dreaming. The return to reality takes place not in the bedchamber, as the opening transition does, but "in the open air, in the early morning, before sunrise" (180). The timing of the event emphasises the return as an awakening from sleep. The setting of the scene as "in the open air," furthermore, reverses the extensive emphasis placed on inward movement that characterised Anodos' entry to the fantasy world.

While Phantastes is clearly a novel concerned with identity, part of that concept necessarily involves the mortality of the individual, and there are a number of ways in which Anodos' adventure in Fairy Land can be read as an allegory for life itself. This becomes particularly apparent in the later chapters of the book, where the epigraphs too become concerned with the nature of the angelic. The penultimate chapter takes as its epigraph lines from Abraham Cowley's poem "Life" (one of his "Pindarique Odes" 1656). The poem describes the limitations of the human

\footnotetext{
${ }^{34}$ This verse translation from the original German prose appears to be one of MacDonald's own. Significantly, the original does not refer to a mirror at all.

35 See Introduction for a discussion of the literary influence of the German Romantics, including Novalis, on George MacDonald's fiction and philosophy.
} 
perspective in viewing death as finality. This view is placed in contrast to that of the angelic, for which Death is the beginning of something much larger:

This wretched Inn, where we scarce stay to bait,

We call our Dwelling Place:

We call one Step a Race.

But angels in their full enlightened state,

Angels, who Live, and know what 'tis to $B e$,

Who all the nonsense of our language see,

Who speak things, and our words, their ill-drawn pictures, scorn

When we, by a foolish figure, say,

Behold an old man dead! then they

Speak properly, and cry, Behold a man-child born!

(Cowley 7-16 original italics)

While the language of the poem highlights once again the importance of perspective in distinguishing between the human and the angelic states (the difference lies in how each "behold[s]" death, for example), it is the sense of landscape invoked which I find most interesting. While we have already spoken about the transition in MacDonald's novel from reality to fantasy, and the significance of this in terms of mental states, the shift to a focus on the movement between life and death, the mortal and the immortal, as is evidenced by the concluding episodes of the novel, is an extension of the novel's primary concern with human identity. Fairy Land becomes, by the end of the novel, not just an exploration of the human self, but one of the human soul, which has the power to transcend mortal life. As Anodos describes himself moving from being buried beneath the ground, to reincarnation as "a single large primrose that grew by the edge of the grave" (178), and finally to attaining the height of the clouds, from which vantage point he can observe the activity on the earth below, he concludes that "[a]1l true love will, one day, behold its own image in the eyes of the beloved, and be humbly glad" (179). The two realms, irreconcilable in the main body of the text, as is shown by the relationships between Anodos and the marble lady, are made one in MacDonald's concept of an afterlife. We are reminded of the conclusion to Beddoes' "Pygmalion," in which the sculptor too dies, but where the final scene is of him reconciled with his love, "quietly / Weeping the tears of his felicity" (Beddoes 230-1). While the novel does not end with Anodos' ascent to the "realms of lofty Death" (179), his return to the 'real' world is curiously resonant with what is known of the dying process: "a pang and a terrible shudder 
went through me; a writhing as of death convulsed me; and I became once again conscious of a more limited, even a bodily and earthly life" (180 italics mine).

The circular nature of Phantastes' narrative, characterised throughout by its appeal to a dream sequence, brings us finally to a last crucial thread defining the web of discourse. Throughout the novel, reference is consistently made to the act of story-telling, and Anodos' adventure in Fairy Land, as well as his life in general, as a process of story-telling. ${ }^{36}$ When, for example, Anodos first enters Fairy Land, he is teased by the goblin-fairies about the fact that "[h]e has begun a story without a beginning, and it will never have any end" (33). This notion of his life as a story is maintained in his experience of taking on the role of the protagonist in the stories he reads in the Fairy Palace. The way in which he emerges from these readings once again connects story with life: he remains immersed in the fiction world until, "grown weary with the life of years condensed in an hour, or arrived at my deathbed, or the end of the volume, I would awake" (81-2). This description mirrors closely what happens at the end of the novel: Anodos (and his reader) arrives at his deathbed (even moving beyond it to an afterlife), but then awakens to recognise reality. In Phantastes, MacDonald is pointing to the power of narrative to reflect life, and of life itself as the playing-out of story.

\footnotetext{
${ }^{36}$ This is further reinforced, of course, by the intertextual nature of the use of epigraphs.
} 


\section{Chapter Two: \\ "Beginning from the inside": healing stories in Adela Cathcart}

\section{Introduction}

George MacDonald's 1864 novel, Adela Cathcart, is the story of a depressed young woman, who is cured by the telling of stories. That something is wrong with the young heroine is made clear in the first chapter. The leading words addressed to her by her uncle (the narrator) are, "Adela, my dear, what is the matter?” (12). Adela's reply, "I don't know, uncle," is necessarily vague, as are any details of her illness provided by the narrator. This imprecision may perhaps be explained by the fact that the development of the novel's remaining plot centres around its interpretation. The various stories told by the different characters surrounding Adela have an accumulating positive effect on her condition, thus enabling a projected diagnosis of depression to be retrospectively derived. The intersecting approaches of close reading, intertextual framing, and the placement of the narrative within its contemporary medical context will be used to illustrate that the novel's central concern (as was that of Phantastes) is with the inner workings of the mind, in this case that of the depressed individual. The technique of embedded storytelling in the novel functions in a similar way to those fantastic elements of Phantastes by providing a means of exploring a mental landscape. But while in the world of Phantastes the mind was all, in Adela Cathcart storytelling becomes a means of showing the mind in a necessary state of interaction with the outer (specifically social) world. In doing so a paradox is revealed: the storytelling process enables Adela to heal herself from within, at the same time as encouraging her to engage with the world around her.

The novel opens with its narrator, John Smith, arriving by train to spend some weeks over the holiday season at the home of an old friend, Colonel Cathcart. His relationship with the family is such that he refers to the Colonel's daughter, our eponymous heroine, as his "niece," and she to him as her "Uncle." When Smith 
arrives at The Swanspond (the Colonel's home), however, he is shocked to discover a dramatic change in the physical health of Adela since he saw her last: where once she had been "merry enough," she is now characterised "not so much [by] sadness as utter and careless hopelessness" $(13,12)$. Her father has no clue as to what has caused this decline; nor, for that matter, has Adela herself any real idea (that the reader is given access to, at least). The old family doctor and his prescriptions are having no effect on her condition either way, and the Colonel is ready to give up hope. After observing a slight improvement in Adela's face and attitude, however, after a visit from the schoolmaster and his wife during which a story is told, Smith, in consultation with a young doctor newly arrived in the neighbourhood, determines a plan to cure her. He devises a story-club, at which a number of guests gather together to share stories. Those chosen to make up the number of story-tellers include Mr Bloomfield (the schoolmaster) and his wife; the young doctor, Harry Armstrong; Dr Armstrong's brother, the curate; the Colonel's sister, Mrs Cathcart, and her son, Percy; and of course the Colonel himself and our narrator, John Smith. Each person takes a turn to narrate a story, some more than one. The hope is that these will provide enough interest on the part of Adela to cure her of her ennui.

The structure of the novel, consisting of a number of stories enclosed within a larger, framing, one, is part of a long tradition, which includes The Thousand and One Nights (first published in English in 1706), Boccaccio's Decameron (c1351), and Chaucer's Canterbury Tales (c1390). ${ }^{37}$ According to Robert J. Clements, the contents of the Italianate novella are not usually closely influenced by their surrounding circumstances. Instead the framework (or cornice) of such a collection of stories was often based upon "an unhappy act of God or deed of man": for example, the plague or the siege of a city (259). As a result, the stories themselves were often rather light and humorous to counteract the horror of the context which prompted them. At the same time, the cornice tended to function, through its serious nature, to counteract the triviality of many of the stories at a time when "literature was supposed to be a handmaid to theology" (Clements 259). The framework of the Italian stories was not always completely serious and moralistic, however, allowing also for intermediary activities to be performed and described (such as singing, the reading of poetry, and banqueting) as aftermaths or intervals in the story sessions.

\footnotetext{
${ }^{37}$ By the eighteenth century, with a few notable exceptions, this framing device was on the whole only a feature of past narratives (Clements 261).
} 
Longfellow's contribution to such a collection of stories, Tales of a Wayside Inn (1863), was published just one year before MacDonald's Adela Cathcart. Whether or not MacDonald was influenced by Longfellow, who had achieved widespread fame and popularity in Europe and in England by the 1860s, the two were to become personally acquainted when MacDonald visited America on a lecture tour in the 1870s. There are certainly similarities between Adela Cathcart and Longfellow's collection. In Tales of a Wayside Inn, a group of friends, gathered around a fireplace, take turns to narrate stories. The characters are, notably, all male, but come from a variety of nationalities, professions and social positions. There is of course the innkeeper himself, the first to narrate, followed by a "Student of old books and days" (I.116); a young Sicilian (who likes to read poetry and the works of Boccaccio); a Spanish Jew (well-versed in the stories of Pierre Alphonse and Hebrew books); and a theologian, a poet, and a musician. Of this group of characters, each has "his tale to tell, and each / Was anxious to be pleased and please" (I: 87-88). The stories, therefore, have entertainment as their explicit purpose, and there is no significant difference, in subject or tone, between the stories and their cornice (as was suggested by Clement in reference to the Italian stories).

Such a relationship between the two components of the narrative is similarly absent (at least to an extent) in Adela Cathcart. ${ }^{38}$ Both components contain the same grounding in moral teaching, which is perhaps not surprising given MacDonald's interest and background in theology. While the framing narrative emphasises singing and the reading of poetry, it never strays from its moralistic path. As in the earlier examples of the genre, the framing narrative of MacDonald's novel establishes a realistic and localised setting that fulfils what Clements has identified as "unity of place" (7). The realistic setting allows for the commentary and intrusion of the characters on the individual stories. Mrs Cathcart, Adela's aunt, is a prime example of this. Her adverse reaction to the basis in superstition of the story of 'The Cruel Painter,' told by Dr Armstrong, allows the story to then be justified by MacDonald through the reply of the doctor. The device creates distance between the stories and the reader, but also from the author himself. The listeners within the novel exemplify interpretation. The reader is thus invited to adopt a critical, reflective approach to stories that might otherwise be dismissed as fanciful and cheap

\footnotetext{
${ }^{38}$ The chapter as a whole will go into more detail as to the relationship between the framing narrative and certain specific stories.
} 
(as was commonly thought, for example, of the gothic, or "sensation," novel at the time $\left.^{39}\right)$.

While establishing the unity of place, as Clements notes, framing narratives often conform, quite consciously, to a unity of time (261). The Canterbury Tales, famously, is set in Spring, in the Lenten period. In Adela Cathcart, the story is set at Christmas, providing ample opportunity for the sorts of social gatherings necessary to implement Smith's cure of Adela. The season highlights the importance of family groupings and friendships, which is then seen in both the framework and in the inlaid stories. But there is not an imposed external time limit on the story-telling activities, as was common in the earlier collections of tales. Rather, any limit becomes more apparent as the novel progresses: as Adela's health improves, and the relationship between herself and Dr Armstrong grows more intimate.

While the stories told by the group of friends in Longfellow's Tales of a Wayside Inn are performed primarily "to please" (I.88), those found in Boccaccio's Decameron were explicitly set to have a more profound effect on their audience. At the end of the tenth tale of the ninth day, for example, Pamphilus introduces the theme for the next day's tales: "such persons who have done some gallant or generous action, either as to love or anything else" (Boccaccio 465). He goes on to profess the hope that "these will kindle in our minds a generous desire of doing the like" (466). The idea of stories as a means of significant influence on their listeners' lives is also an important aspect of Adela Cathcart, where the concept of narrative itself as well as the storytelling atmosphere is treated as therapeutic. It is, therefore, illuminating to set Adela's illness and cure against the background of prevailing theories relating to mental (and in particular depressive) illness in the mid-nineteenth century.

\section{"Morning thoughts are true": hysteria and depression}

Although Adela is not obviously 'hysterical,' the nineteenth-century concept of hysteria is relevant. As we shall see, it illuminates both Adela's condition and (more particularly) her cure - through what might be termed 'distraction.' Hysteria was

\footnotetext{
${ }^{39}$ George Eliot, for example, complaining to John Blackwood, in a letter of 1860, about the popularity of contemporary sensation novelist Mary Braddon's books compared to her own, writes "I sicken again with despondency under the sense that the most carefully written books lie, both outside and inside people's minds, deep undermost in a heap of trash" (Haight 309).
} 
extraordinarily prominent in nineteenth-century medicine and culture. It has been noted that the hysteric condition "presents in direct and personal form the key questions of gender and mind/body relations" (Gilman et al. vii). Women at this time were generally expected to be childlike and dependent. In other words, their position was such that the "incapacitating [physical] symptoms" characteristic of hysteria can be seen to reflect the sufferer's actual condition: helplessness, enfeeblement and restriction (Gilman et al. vii). Paradoxically, their hysteria is today seen by critics as a neurotic attempt by these women to gain control over their lives. In fact, many nineteenth-century physicians viewed the condition rather similarly - as strategic attention-seeking behaviour.

The idea that patients of hysteria were in fact using their condition to manipulate those around them led to a concept of 'morbid' self-attention, and a form of treatment involving the distraction of a patient's thoughts away from themselves. The prominent Victorian physician Henry Maudsley warned in Responsibility in Mental Disease (1874) that "by self-introspection and self-analysis [...] a morbid egoism is fostered $[\ldots][\mathrm{A}]$ tender conscience of that kind, over-rating its own importance, may easily pass into insanity, unless counter-balanced by the sobering influence of active outward preoccupations and interests" (298). William Bevan Lewis, in A Texbook of Mental Illness (1890), makes a similar argument when he notes that the condition of mental depression (frequently an associative illness of hysteria) necessarily involves an increase of "subject-consciousness" at the expense of "object-consciousness": "The subject broods over his multi-form and novel feelings - morbid introspection and egoistic musings replace the healthy altruistic feelings and sentiments" (Lewis 126). Lewis defines depression in the following terms:

Corresponding to [a want of vigour] there is a rise in subjectconsciousness, shown in the prevalence of painful mental states - the predominance of gloomy emotions. This is the positive aspect of the patient's mental state, and this aspect is the one which chiefly obtrudes upon our notice. It is characterised especially by an all-prevailing gloom, varying in degree from mild depression up to acutely painful mental states. The subject may complain of vague anxiety - a feeling of some impending evil - an indefinite prevision of coming sorrow, which gives its own colouring to objective existences: he retires from social converse, which but adds to his irritation and mental distress, gives himself up to introspective states, in which he dwells upon the present contents of his mind, broods over his morbid 
feelings, and falls into long reveries, the subject-matter of which partakes of the same gloomy colouring. [...] Even in this reticence and retirement from social responsibilities, this growing apathy to all around or feeling amounting to dislike or direct hostility, we recognise the origin of that subjectivity, that egoistic state which, in more advanced affections of the mind, conjures up delusions of encroachment and persecution. (117)

This passage highlights the source of the problematic behaviour involved in depression in the relationship between the individual subject and society: this desire to shift the morbid self-attention of the depressed individual outward to their surrounding social sphere is (as we shall see) one highly significant to MacDonald's novel also.

The idea of dangerous introspection extends beyond studies of hysteria and depression. A commonplace in nineteenth-century discussions of insanity, it was thought to be curable by a redirection of morbid thoughts and feelings in an altruistic, or outward, direction. Writing in 1871 on insanity in general, renowned Victorian psychiatrist George Fielding Blandford (1829-1911), for instance, explained that " $[\mathrm{b}] \mathrm{y}$ the moral control exercised personally by man over man, the patient's thoughts and feelings are to be directed from his morbid self-contemplation to that care and concern for others which is his normal state" (379). Treatment for such illnesses as hysteria, therefore, typically involved the removal of the patient from familiar surroundings, including family members, and their placement under complete doctor control. The "rest cure", as it was known, forced a patient to remain in bed with no outside contact, except that involving the doctor and one nurse (not a friend or acquaintance), until the lack of social interaction made them accept enthusiastically the doctor's order to get up and take some sort of exercise. Focus was then placed on strenuous physical activities in the hope that they would distract the patient from introspection.

Adela's condition certainly resonates with this particular complex of notions. Although clearly not a classic hysteric (her depicted experience lacks the fits or other overt - or "positive" - physical symptoms commonly associated with the condition), her symptoms certainly correspond to a more general "decline" or depression. In fact, we are told that her mother died "of a decline" several years before, and it is this that has heightened the concern of her father (14). Adela is also, like the hysterics of mid-nineteenth-century medical literature, young, female, of the 
upper classes, and resident on an estate far from any real society. Mr Smith, the narrator, has to travel many miles by train in order to visit them, and it is clear from the butler's reception on his arrival that visitors are few and far between: he himself, during "twenty years in the colonel's service," has "never been to London" (11).

As previously mentioned, we are not provided with much insight into Adela's own thoughts regarding the nature of exactly what is troubling her. Her symptoms remain vague, in both her words and the narrator's. Adela's attempt to articulate her own state of mind for the benefit of her uncle, however, does resonate with the medical description above:

I woke suddenly one morning, very early, - I think about three o'clock, - with an overpowering sense of blackness and misery. Everything I thought of seemed to have a core of wretchedness in it. I fought with the feeling as well as I could, and got to sleep again. But the effect of it did not leave me next day. I said to myself: "They say "morning thoughts are true." What if this should be the true way of looking at things?' And everything became gray and dismal about me. Next morning it was just the same. It was as if I had waked in the middle of some chaos over which God had never said: 'Let there be light.' And the next day was worse. I began to see the bad in everything, wrong motives, and self-love, and pretence, and everything mean and low. And so it has gone on ever since. I wake wretched every morning. I am crowded with wretched, if not wicked, thoughts, all day. Nothing seems worth anything. I don't care for anything. (25)

This, then, is the extent to which we are given, as such, a "first-hand" account. We are not supplied with any definite cause for her state of mind, although her uncle (the narrator) thinks she may have suffered in "[s]ome love affair" (13). ${ }^{40} \mathrm{He}$ also worries about her demeanour:

In all [Adela's] behaviour, so far as I had had any opportunity of judging, she had been as good as my desires at least. But there was a want in her face, a certain flatness of expression, which I did not like. I love the common with all my heart, but I hate the commonplace; and, foolish old bachelor that I am, the commonplace in a woman troubles me, annoys me, makes me miserable. Well, it was something of the commonplace in Adela's expression that had troubled me. (285)

\footnotetext{
${ }^{40}$ The narrator's suggestion here is interesting in light of the novel's conclusion: the result (or symbol) of her cure is her engagement to Harry Armstrong; in other words, a successful "love affair."
} 
Smith defines Adela's problem in terms of a spiritual weakness, rather than a mental or physical one: "the light within had not been kindled, else that face of hers would have been ready enough to let it shine out [...]. Her soul was asleep" (285).

Furthermore (and here we return to the subject of the self), she has a "worldliness that lay only in the use of current worldly phrases of selfish contentment, or selfish care" (italics mine).

But, as a quasi-hysteric condition, Adela's illness must also be attributed to a lack of social and intellectual stimuli. She has been left to stagnate in the social backwater of 'Purleybridge,' the hamlet to which 'The Swanspond' belongs. Significantly, a 'purley' (or 'purlieu') is, according to the $O E D$, "a tract of land on the fringe or border of a forest" or, in plural form, "the outskirts or surroundings of any place; the environs, the borders" ("purley", n., 1.a; 2.a). While 'bridge' might suggest some sort of possible hope for the future, it is also an in-between place, a border-land. Adela's situation, then, is one of isolation. MacDonald expresses sympathy for this on one level, invoking a cure through society and outside interest, but in other ways his implicit theory is that of the dominating physicians of his time: Adela is ultimately cured by marriage.

Not only do the symptoms of Adela's illness, as described by herself and by her narrator, resonate with these notions of morbid attention and inwardness, but the cure devised within the novel does the same. The idea that a person can be cured of a depressive state of mind through the companionship and distraction of a story club, as well as the development of a romantic attachment, reflects a concept of the self that is to a certain extent dependent on others for fulfilment. So, for example, after hearing the telling of the final story, 'The Castle,' a parable about God's relationship with his Church, the narrator describes Adela as having returned to full health: "I have never seen her so well [...] her step was as light, and her colour as fresh, as her lover even could wish to see them" (408). ${ }^{41}$ The interest Adela has had in the story club, in the stories themselves and in the people telling them, has clearly worked to divert her morbid thoughts.

\footnotetext{
${ }^{41}$ The reference to Adela's 'lover' here is significant. Overtly, of course, it refers to Harry Armstrong, who has just declared his love to Adela and is in the process of trying to convince the Colonel to let him marry her. But, on another level, it reinforces the (for the reader at least) rather uncomfortable nature of the relationship between Adela and Smith, and the close way in which he observes her - in an almost voyeuristic fashion. Smith seems to embody a range of characteristics when it comes to his relationship with Adela: diagnostician, organiser, intruder, voyeur, family friend, negotiator, commentator.
} 
On the surface level of the story, then, it appears that MacDonald aligns himself with contemporary medical and philosophical discussion of hysteria, and other forms of mental aberration, through this concept of morbid "subjectconsciousness" as outlined above. Smith, in discussing Adela's case with her father, Colonel Cathcart, speculates

If we once got her interested in anything, it seems to me, as $\mathrm{Mr}$ Armstrong has already hinted, that the tide of life would begin to flow again. She would eat better, and sleep better, and speculate less, and think less about herself, - not of herself, - I don't mean that, colonel, for no one could think less of herself than she does. [...] It would be beginning from the inside, would it not? (48)

The solution suggested by Mr Smith, as we know, is the invention of a story club which will draw Adela's attention out. However, the obvious relevance (in varying degrees, it must be admitted) of each individual story to Adela's own condition, necessarily implies, on the part of Adela and the other characters, some level of selfconsideration, however displaced. In fact, what is actually occurring, I would argue, is that the patient is placed in the position of the analyst, and is thus required to consider the events in each story and their relevance to her own position. Adela is being asked to think about her self, but through the medium of story. The displacement of self is thus central to the method.

Adela's treatment, therefore, while working towards the same end as those of MacDonald's contemporaries in the medical field, differs from the standard nineteenth-century prescriptions in that the stories told to her mirror Adela to herself. While physicians in the nineteenth century worked on distracting attention away from the patient's self by such activities as physical exercise, and reinforced this by their removal from a familial environment, MacDonald appears to be working with the opposite approach. Firstly, Adela remains living with her family, and, if anything, is gifted with an even larger network of friends, through the introduction of the story club members into the household. But the most important way in which MacDonald diverges from the established medical path is through the telling of stories.

Freud, writing several decades after the publication of Adela Cathcart, was to find himself listening to the stories told by his patients, and using these to work out and purge repressions and psychoses. In MacDonald's novel, however, the 
doctor finds himself compelled to tell his own story. And it is Adela, along with the reader, who must interpret it. The catharsis, therefore (which is suggested by our heroine's surname), is not carried out directly by Adela, the patient, but by her team of (almost literal) consultants. ${ }^{42}$ This method reflects MacDonald's idea, present elsewhere (though perhaps most notably in his Unspoken Sermons) that the 'Self' is in fact the 'shadow' of the individual; it is thoughts of the self that inhibit an individual's spiritual development. ${ }^{43}$ But MacDonald's strategy involves, somewhat paradoxically, a focus on Adela - at least in so far as the stories apply to her.

\section{'The Light Princess'}

The first story to be told as part of the "story club" is 'The Light Princess.' It is told by the narrator, Smith, who describes it as "a funny kind of fairy-tale, which has been growing in [his] brain for some time" (49). In a re-telling of the well-known 'Sleeping Beauty' story, a princess is born to a king and queen, but is cursed at her christening by her aunt, a witch angry at being left off the guest list, with a lack of gravity. The curse results in the princess lacking both physical and emotional gravity: she cannot cry or comprehend the serious nature of anything. At first glance, then, the events in the story appear in direct contrast to those of the framing narrative. The princess, unlike Adela, must be far from depressed. The story, furthermore, was written (though it had remained unpublished) prior to the novel. It is introduced in the novel, however, by Smith with a quotation from Milton's "Il Penseroso" (1645), which brings with it the idea of depth in meaning:

\section{Great bards besides}

In sage and solemn times have sung

Of turneys and of trophies hung;

Of forests and enchantments drear,

Where more is meant than meets the ear.

(54 italics mine)

\footnotetext{
${ }^{42}$ Adela's surname, Cathcart, is too close in spelling, and in significance, to cathartic, or catharsis, for it to be a coincidence; MacDonald was clearly aware of the connotations when he chose it for his protagonist. Catharsis, according to the $O E D$, can mean "the purification of the emotions by vicarious experience" $(O E D, \mathrm{~b})$, while the definition of cathartic reads "cleansing, purifying, purging" (OED, A adj., 2).

${ }^{43}$ See, for example, the discussion in the previous chapter of the shadow in MacDonald's earlier novel, Phantastes.
} 
We, along with Smith's audience, are thus clearly invited from the beginning to act as interpreters of what follows. The characters of both the witch and the princess in 'The Light Princess' symbolise parts of one individual, namely Adela. This can be seen in the parallel imagery used to describe the witch's cursing of Adela, and the nature of Adela's illness as interpreted by the narrator, the doctor and the curate. ${ }^{44}$

The depiction of the witch, Makemnoit, becomes crucial to a discussion on the treatment of the self in MacDonald's novel. Smith reads, "I never heard of her loving anybody but herself, and I do not think she could have managed that, if she had not somehow got used to herself' (56). This account of the witch clearly places her in the position of Adela, in terms of her relationships with other people and her attitude to herself. We have, for example, already seen Adela's illness described in terms of a loss of love for others. All she can manage in this area is a "hope" that she loves her father, followed by the confession, “I don't know. I don't feel as if I did" (25). Adela's own description of her condition, furthermore, lends further evidence to the parallel: "I am crowded with wretched, if not wicked, thoughts, all day. Nothing seems worth anything. I don't care for anybody" (25). This notion of "wicked thoughts" suggests the wickedness of Princess Makemnoit, as does the lack of care for others. However, Adela is not portrayed in the novel as wicked; this is reserved for her own view of her inner self. This leads to the conclusion that it is only one part of her that is represented by the witch. For the other half, we must look towards the 'light' princess herself.

As mentioned above, the princess's loss of gravity is at first glance the complete inverse of that affliction suffered by Adela. She cannot see the serious side of anything, and is unable to cry; whereas Adela is quite clearly portrayed as depressed and constantly dwelling on "the bad in everything, - wrong motives, and self-love, and pretence, and everything mean and low" (25). However, as William Gray has argued, "both Adela's depression and the princess's levity could be interpreted as 'hysterical', in various senses; both can be seen not only as curses, but also as obstacles, even resistances, to growth into full womanhood" (Gray 2009, 52). Furthermore, the princess's levity is not represented as pure eternal happiness:

[I]n her laugh there was something missing. What it was, I find myself unable to describe. I think it was a certain tone,

\footnotetext{
${ }^{44}$ This relationship between the curse in the story and Adela's illness will be explored in greater depth in what follows.
} 
depending upon the possibility of sorrow, - morbidezza, perhaps. She never smiled. (66)

It is in this important distinction of "a certain tone" that we really see a reflection of Adela's illness.

The reflection of Adela's illness in that of the princess is highlighted further by a conversation between the king and queen as they attempt to console each other over their daughter's affliction. The queen suggests that they "wait until she is older. She may then be able to suggest something herself. She will know at least how she feels, and explain things to us" (64). This in itself is curious, as Adela, at twenty-one years of age, should be considered old enough to fulfil these requirements. However, if we are reading the princess as Adela, according to Smith and the doctor, her growth has been stunted in a spiritual sense; she is still uninformed and thus "child-like." $" 45$ As the curate says, at this stage she "has been fed upon slops, and an atrophy is the consequence. My hope in your plan is, partly, that it may furnish a better mental table for her for the time, and set her foraging in new directions for the future" (50). This progression from provision by others to self-sustenance reflects the growth from childhood into adulthood as we observe in the fairy tale.

Once the princess has grown up into a young woman she discovers a love of water, which restores her, for the time during which she is immersed in it, "to the ordinary human gravity" (73). Swimming becomes her passion and she is "always the better behaved and the more beautiful, the more she ha[s] of it" (72). The princess's comfort in the womb-like water suggests not only a prenatal state from which she must detach herself, but also the possibility of a spiritual rebirth. The wicked witch, however, upon discovering that her niece has found a source of happiness despite her curse, once again takes action. It is at this moment that a significant shift occurs in the fairy tale, and where the story as a reflection of Adela's condition really comes through. With the draining of the lake, the princess loses her characteristic vitality. Whereas in the first half of the story the events are seen to invert Adela's own situation, the second half develops into an almost direct

\footnotetext{
${ }^{45}$ I do not mean "childlike" in the sense that MacDonald himself usually does - an idealised state towards which we should all be working. See, for example, his sermon "The Child in the Midst" for a full discussion of MacDonald's attitude towards "the childlike". In this context I simply mean immature and undeveloped.
} 
replica. The princess, too, is reduced to a state of abject depression, drawing on those symptoms hidden earlier beneath her "lightness":

For the princess kept her room, with the curtains drawn to shut out the dying lake. But she could not shut it out of her mind for a moment. It haunted her imagination so that she felt as if her lake were her soul, drying up within her, first to become mud, and then madness and death. She brooded over the change, with all its dreadful accompaniments, till she was nearly out of her mind. [...] [S] he seemed to have forgotten her father and mother too. (87)

The parallels are thus strikingly clear. Both young women are obsessed with "dreadful accompaniments," and both are furthermore losing empathy for even their closest family members.

The behaviour of the witch at this point replicates what the narrator understands to be Adela's problem in terms of inwardness and a morbid focus on the inner self. In the above extract the lake is referred to as if it were the princess's "soul." The image is reinforced when its sinking is associated with "lovely creatures dying, and ugly creatures coming to life, like the unmaking of a world" (83). Now of course it is the witch who is causing the lake level to sink as she has been draining it from a secret cave beneath, by the means of "one of those dreadful creatures which few have ever beheld, - the White Snakes of Darkness" (84). There is great emphasis on the motions she undertakes in order to achieve this, and an especial focus on the inward direction involved:

[The witch] then untwined the snake from her body, and held it by the tail high above her. The hideous creature stretched up its head towards the roof of the cavern, which it was just able to reach. It then began to move its head backwards and forwards, with a slow, oscillating motion, as if looking for something. At the same moment, the witch began to walk round and round the cavern, coming nearer to the centre every circuit; while the head of the snake described the same path over the roof that she did over the floor, for she held it up still. And still it kept slowly oscillating. Round and round the cavern they went thus, ever lessening the circuit, till, at last, the snake made a sudden dart, and clung fast to the roof with its mouth. 'That's right, my beauty!' cried the princess; 'drain it dry. ${ }^{46}$ (85)

\footnotetext{
${ }^{46}$ The speaker here is the witch-princess, but the ambiguous reference only to princess is perhaps telling, especially in light of my argument that the two are really components of the one whole.
} 
This image of the witch and her snake working centrally, from within, with such an emphasis on this "oscillating" movement, not only lends strength to the idea the two characters are really both parts of the one whole, it also pre-empts a description of the self as described by the curate as he is telling Smith his own story:

$[\mathrm{I}] \mathrm{n}$ every one $[\ldots]$ there lies a secret chamber, to which God has access from behind by a hidden door; while they know nothing of this chamber; and the other door, towards their own consciousness, is hidden by darkness and wrong, and ruin of all kinds. (164)

Now while the story of the light princess describes an evil witch as the presence behind the secret door to the self, and in the curate's story the presence is God, the underlying nature of the idea is the same. In both scenarios, the self is localised, portrayed as a physical space that external agents can penetrate and act within.

The solution to the problem of the lake's loss of water is given by an inscription on a gold plate found in one of the last remaining pools. The inscription reads that only when a man sacrifices his own life to plug up the hole, will the lake refill and the princess, too, return to life. This position is filled (quite literally) by the prince, who has met and fallen in love with the princess earlier in the story, through their shared love of swimming. The hole in the lake which he has to fill is, unsurprisingly, in the very centre, a "three-cornered hole, of no great size" (91). ${ }^{47}$ The prince thus enters the "heart of the lake" enabling it to re-fill with water, and the princess to regain her health. Not only this, however, but the act of saving the prince from his own selfless gesture as she does, and thus relinquishing her own self-love, enables the princess also to regain her gravity. The fate of the witch, furthermore, is that her house is undermined by the water beneath it; it caves in, "burying her in its ruins, whence no one ever ventured to dig up her body" (97). The selfish and vindictive aspect of the self is thus destroyed, also from within. The conclusion of the story celebrates selflessness, with a retelling of a popular nursery rhyme: the king divides up all the money in his counting house and the queen the honey in her parlour, each distributing all to the kingdom's children.

\footnotetext{
${ }^{47}$ The number three is often thought of as a symbol for wholeness: Plato split the soul into three parts (the appetitive, the spirited and the rational); Aristotle saw the individual as made up of mind, selfknowledge and self-love; Hegel wrote about three spirits (the subjective, the objective and the absolute); and of course Christianity's holy Trinity.
} 


\section{'The Bell. A Sketch in Pen and Ink'}

As with the telling of 'The Light Princess,' the narration of 'The Bell,' by the curate, is explicitly shown to be relevant to Adela and her illness. Once again, the storytelling activity is one of displaced reflection rather than distraction for the 'patient.' 'The Bell' tells the story of a young woman called Elsie, who suffers from a peculiar sensitivity of feeling. Right from the start we can see a similarity to Adela with her "two blue eyes, over which some inward trouble had spread a faint gauze-like haziness" (105). The description of this "inward trouble" is expanded to reveal a character that is
excessively and painfully sensitive, as if her nature constantly portended an invisible multitude of half-spiritual, half- nervous antennae, which shrunk and trembled in every current of air at all below their own temperature. The effect of this upon her behaviour was such that she was called odd; and the poor girl felt that she was not like other people, yet could not help it. (108)

We can see that MacDonald's focus in this story is once again on the individual and her aberrant state of mind. The story is a character sketch of a young woman who is unhappy and unloved. We are told that both of Elsie's parents are dead, and that her brother is insensitive to her emotional needs, lacking even "the remotest feeling of curiosity as to what the inward and consistent causes of the outward abnormal condition might be" (108). As a young child Elsie suffered from epileptic fits, and the return of these in her present state is a further sign of her decaying health. I would argue that the placement of an actual physical illness alongside the mental one functions as validation of the latter, and that such validation of mental disturbance extends to Adela's case as well. The physical provides a way in, as it were, to the mental.

Elsie's condition, furthermore, is reinforced by its placement alongside that of the old fool, "Feel Jock." The fool is an important figure in MacDonald's fiction, through his nearness to "the infinite and unseen" (106). ${ }^{48}$ In this story, the two characters of Elsie and Jock are placed side by side, and their similarities come from their mutual misunderstanding by society, the fool as result of his lack of intellect

\footnotetext{
${ }^{48}$ Chapter Six of the thesis looks in more detail at MacDonald's use of the fool in the character of the "mad laird" in Malcolm.
} 
and Elsie through her extreme sensitivity. Both conditions set their sufferers apart from society:

It is curious how certain diseases repel, by a kind of awe, the sympathies of the neighbours; as if, by the fact of being subject to them, the patient were removed into another realm of existence, from which, like the dead with the living, she can hold communion with those around her only partially, and with a mixture of dread pervading the intercourse. (108)

The idea of another realm of existence is crucial to MacDonald's philosophy. In this story and in the novel in general, we see an interest in the existence of the individual, and that existence in relation to others. The focus is on the inward state of the individual as opposed to that accessible by others: "Thus some of the deepest purest wells of spiritual life, are, like those in old castles, choked up by the decay of the outer walls" (108). It is the deterioration of this inner life which is affecting Elsie, and, we can infer, Adela, "the border land between body and mind, in which her disease lay" (118).

Elsie, however, unlike Adela, is given the release of death. Her condition is not redeemable in life, and her death, along with the fool's, is seen as a positive event, a form of coming home: "surely they found the fire burning bright, and heard friendly voices, and felt sweet lips on theirs, in the home to which they went" (119). This plays out the refrain of "come hame," plaintively offered by the fool throughout the story. The motivation of the overall novel, however, being to prevent Adela's death, immediately draws attention to the differences in the two circumstances. The warm fire and friendly voices signifying "home" in the above description immediately recall the circumstances in which the wider story is told: a group of friends are gathered together in front of a warm fireplace to tell each other stories. We can see that what was missing for Elsie in her life is in fact right there for Adela. ${ }^{49}$ Coming home for each character, then, takes a completely different form (for one it is death, for the other, life), yet both are portrayed using exactly the same imagery. It is this similarity in difference that Adela is asked to consider with the telling of this story.

\footnotetext{
${ }^{49}$ Just before the previous story was read, the clergyman rearranges their seating, arguing, "having such a jolly fire it was a pity not to get the good of it" (53-4).
} 
It is in Adela's response to the story of 'The Bell' that we see perhaps the greatest difference from more contemporary forms of therapy. It is made explicit that she is expected to draw relevance from the story to her own condition:

Adela offered no remark upon the story, and I knew from her countenance that she was too much affected to be inclined to speak. Her eyes had that fixed, forward look, which, combined with haziness, indicates deep emotion. [...] I had thought, while the reader went on, that she could hardly fail to find in the story of Elsie some correspondence to her own condition and necessities; I now believed that she had found that correspondence. More talk was not desirable. (120-121)

At the outset of the story it is made explicitly clear that the aim of the story-club is to distract Adela's attention away from herself, and now we see a distinct endorsement of personal reflection. Far from "distracting" her own attention away from herself, the narrator explicitly tells us that "]m] ore talk was not desirable," presumably because it would distract her from considering her own position. 'The Bell' is thus explicitly associated with Adela's condition in the thoughts of the narrator and, we can assume, those of Adela herself. As with the instance of 'The Light Princess,' both the reader and Adela are asked to consider the two scenarios and draw parallels. And what the reader instantly observes is the attention placed on states of mind.

\section{"The homœpathic system"}

The reader is encouraged to conclude that the stories work not in spite of their relevance to Adela but because of it. What might be described as the "distraction" of the heroine is superficial. A better word would be "displacement." While the interest in self for Adela is displaced, its presence is maintained in the stories told by the other characters, and in the narrator's detracting self-references. Or, to put it another way, while the content of the individual stories, and the attitude of the narrator, highlight issues of the mind and the self, the actual form of the treatment itself seems to deny this.

We may, however, understand more clearly the seemingly paradoxical treatment of Adela's cure in homeopathic terms - although the homeopathy involved is purely metaphorical. Before the curate begins his story, for example, the narrator asserts to his reader, "I believe that he had chosen the story on the homeopathic principle" (105). Homeopathy was introduced into England in the 1830s by Dr. F. 
H. F. Quin, a student and successor of the discipline's German founder, Christian Hahnemann. Quin concentrated exclusively on introducing homeopathy amongst medically qualified doctors and their predominantly upper-class clientele (Inglis 85). The association and support of higher society, including many members of the royal family, eased the way for the acceptance of this form of treatment into the British medical marketplace. By 1864, then, it had become an established treatment, though still mainly confined to the upper classes.

When John Smith first arrives at 'The Swanspond' and sees the decline in Adela's health, he proceeds with caution in his discussion of it with her father, Colonel Cathcart: "In his perplexity and sorrow, the poor colonel was irritable and unjust. I saw that it would be better to suggest than to reason. And I partly took the homœpathic system, - the only one on which mental distress, at least, can be treated with any advantage" (14). MacDonald's interest in the subject (coming as it does through analogy) is thus far from conventional. The homeopathic principle also comes into play through the main events of the story; that is, the stories told by the various characters in an attempt to cure Adela's depression. It is this principle, furthermore, which reconciles the two seemingly conflicting attitudes towards the Self in the novel. The fact the each story contains within it some relevance to Adela herself, and her illness, causing her to reflect on her condition through the displacement of narrative, shows MacDonald's unconventional use of an unconventional medical treatment. A small amount of self-introspection is used to counter an unhealthily large one. The "story cure" thus extends a physical therapy into a purely mental (or spiritual) sphere.

What is also made clear in the novel, in connection with the subject of homeopathy, is that a purely medical and physical treatment of Adela's condition is to be rejected as ineffectual, and almost foolish. MacDonald's earliest thoughts of a profession were towards medicine, and he was only prevented from pursuing this career because of his family's inability to support him financially. It is not surprising, then, that this interest surfaces in, and through his novels, with a significantly large number of doctor characters, and doctor-patient relationships, throughout his oeuvre. As is the case in Donal Grant (to be discussed in the fifth chapter of this thesis) the figure of the doctor in Adela Cathcart is treated in two distinctly different ways. The character of Dr Wade, for example, is an older man, whose ineffectual method of treating Adela involves prescriptions: "steel-wine, and 
quinine, and all that sort of thing" (14). His portrayal by MacDonald, especially in its alignment with that of the unpleasant Mrs Cathcart, Adela's aunt, is set in sharp contrast to that of the young and dashing Dr Harry Armstrong: the orthodox medical profession comes under rather a hard blow as even the easy-going Colonel Cathcart complains, "I believe [Dr Wade] knows no more about the state of [Adela's] chest than he does about the other side of the moon. He's a stupid old fool. He comes here for his fees, and he has them" (14). Mr Armstrong, in contrast, explicitly describes himself as "a student of Van Helmont" (51). ${ }^{50}$ This puts him on the side of the narrator, with his early declaration to the Colonel, that he adheres to "the homeopathic system - the only one on which mental distress, at least can be treated with any advantage" (19).

As for the cause (as opposed to the form) of Adela's illness, this seems to lie in her relationship with her father. While not a prominent concern in the novel, the recurring nature of the theme within the stories as well as the outer framing narrative, does suggest a definite interest in the subject on the part of the author. So, while a too-intense focus on the self is viewed by MacDonald as bad for one's mental and spiritual health, he does not put this concern forward as the cause of Adela's illness. Instead, this position is filled by the unhealthy relationship between Adela and her father, the Colonel.

We have already looked at 'The Light Princess' and 'The Bell' in terms of the parallels between those protagonists' states of mind and Adela's. We can also read them in light of the more general setting and supporting characters. Hysteria and other similar conditions affecting young women in the nineteenth century were often referred to as "daughter disease[s]", drawing specific attention to the relationship between the sufferer and her parents. In 'The Light Princess' there is also a distinct emphasis on the way in which the princess, her parents, and the witch interrelate. Firstly, it is through the king's negligence that the princess is cursed with a lack of gravity, forgetting as he does to invite the witch Makemnoit to the christening. Secondly, the curse that Makemnoit places on the princess is significant in this light:

Light of spirit, by my charms

Light of body, every part,

\footnotetext{
${ }^{50}$ This person is assumed to be Jan Baptist van Helmont, the seventeenth-century Flemish physician, philosopher and mystic.
} 
Never weary human arms -

Only crush thy parents' heart!

(57, italics mine)

The focus of the curse, then, is on punishing the parents, but noticeably on crushing their "heart" (singular), as Adela is pronouncedly doing to her father, the Colonel, in the framing story. The association that the hysterical condition has with a need on the part of the sufferer to reverse control in the parent-child (more specifically father-daughter) relationship, adds to the reading that Makemnoit and the princess are actually two parts of the same character. A father's forgetting of his daughter's need for emerging independence is the event alluded to in this instance.

But it is in 'The Cruel Painter,' one of the final stories of the sequence, and one told by Dr Armstrong, that we really see an extended analysis of the relationship between father and daughter, and its effect on the inner self. This interest is echoed in the subject matter of the story: haunting. The motif is significant in the story through its relationship to truth, deceit and the nature of the inner self. Abraham Cowley's 'Hymn: to Light' reinforces this notion and serves to tie these distinct elements together.

\section{'The Cruel Painter'}

Set in Prague, 'The Cruel Painter' tells of a young student, Karl Wolkenlicht, who falls in love with the beautiful daughter of a famous painter, Teufelsburst. Both father and daughter (Lilith) are highly reclusive, and so Karl contrives to become a pupil of the man in order to gain access to the household. But the artist, as we know from the title of the story, is cruel, depicting in his paintings innumerable portraits of suffering. Discovering Karl's feelings for his daughter, he contrives to manipulate his pupil's lovesick state, and thus have him serve as yet another tortured subject for his paintings. To do so he repeatedly drugs Karl with herbs that exacerbate the natural processes of the imagination, but when an overdose makes it seem as if he has died, the painter takes a mould of the corpse to use for his art, and prepares to dispose of the original. Meanwhile, in the neighbourhood there is rumour of a vampire having risen from the corpse of a man who died a few weeks earlier, in the house next door to that of Teufelsburst. When Karl awakens from his coma he at first thinks he himself is a vampire, arising from his coffin, but when he realises what has really happened he decides to keep up the pretence and torment his former 
tormentor. Meanwhile, Lilith too believes that Karl is dead and the fact brings with it the realisation that she could have loved him if only he had lived. This development of feeling separates her from her father, so that when she too discovers the truth about Karl's ruse she does not reveal it. When Karl decides that Teufelsburst has suffered enough he returns to the house as himself and convinces the artist that the haunting was all in his head. The effect on the painter is so strong that he immediately renounces his evil ways and the (rather ludicrous) final image we have of him is as a jolly grandfather figure rolling around the floor "halfsmothered in grand-children" (379).

In his article on redemption in MacDonald's gothic tales, Scott McLaren isolates the interlocking experiences of Teufelsburst and Karl; each becomes in turn the "villain" of the story, inflicting on his victim the throes of suffering in order to gain personal pleasure. Only Lilith remains innocent of this charge, McLaren maintains, but her inability to love (a trait also notably seen in the character of Adela) suggests a similar selfish cruelty that must be renounced. Lilith's position as the model for her father's paintings, furthermore, serves to represent her frozen misery, while the imagery of freezing and winter provides a further link with Adela. She too is described by the narrator as "a frozen bud" (356), and while the sermon at the start of the novel emphasises the cold season's importance in a spiritual sense ("Winter is in truth the small beginnings of the spring" 19), in this story and in the novel at large it is a negative state.

Our first view of Lilith is one which draws parallels to that of Adela in the framing narrative. Lilith is initially depicted as "a woman seated on a new-made grave, not many yards from where he sat, with her face buried in her hands, and apparently weeping bitterly" (348). The grave is that of her dead mother, and the fact that her unhappiness stems from grief at her loss recalls the fact that Adela's own mother has also died, a crucial event in the development of her condition. Karl's response to Lilith is also similar, to both the narrator's and the doctor's in the framing narrative: "the longing to help her whom he could not help drew his heart towards her with a trembling reverence which was quite new to him" (349). The insistence on the idea that it is an absence of the ability to love that is the problem for Adela is similarly emphasised in the case of Lilith. To Karl, "[s]he seemed like one whose love had rushed out, glowing with seraphic fire, to be frozen to death in a more than wintry cold: she now walked lonely without her love" (355). Lilith's 
realisation that she loves Karl, coming after the discovery that he has 'died', is nevertheless enough to enable her to develop a view of life as "a less hard and hopeless thing than before. For it is love itself, and not its responses or results, that is the soul of life and its pleasures" (363). Lilith's development of the ability to love is one of the key morals in the story, and the triumph of the novel overall is in Adela's parallel acquisition of feeling.

Previously, on contemplating his love's lack of response to his intimations, Karl is "compelled" to see Lilith as "in the condition of a rosebud, which, on the point of blossoming, has been chilled into a changeless bud by the cold of an untimely frost" (355). As mentioned above, the imagery of the winter landscape is made use of earlier in the novel, when the curate gives his sermon on the spiritual importance of the cold season: winter is "the childhood of the year" into which "must we all descend" (19). Similarly, it "does not belong to death, although the outside of it looks like death" (19). After the service, Adela is still maintaining a sadness, which even the "sun of righteousness" has failed to melt. Adela and Lilith, therefore, are similar in the idea of their spiritual freezing. Not only does the image of the bud frozen in an "untimely frost" recall the curate's sermon on the symbolic importance of winter to humanity, but what distinguishes the bud from the blossom is its state of inwardness. Both Adela and her meta-literary counterpart are focussed inward, on the self.

Another example of this focus on inwardness and the way in which it forms a link between Adela and Lilith is the strong focus on the theme of death. Karl's feelings for Lilith develop further after he discovers "what a grave of misery her unbelief was digging for her within her own soul" (356). The myriad of ideas contained within this sentence (belief, soul, grave, digging) all carry with them connotations of inwardness, and in particular its association with death and burial. These ideas, too, recall the sermon at the start of the novel, in which Adela fails to have any faith, or belief.

As in the case of Adela, we are not given many opportunities for insight into what Lilith is thinking. The narrative is primarily from the point of view of Karl, and to a slightly lesser extent, Teufelsburst. When Karl first disappears, however, there is one brief moment in which Lilith's thoughts are available to us: "Was he dead? What did it matter? They would all be dead soon. Her mother was dead already. It was only that the earth could not bear more children, except she devoured 
those to whom she had already given birth" (362). The hopelessness apparent in these lines recalls Adela's attempt to explain her condition to her uncle: "I am crowded with wretched, if not wicked thoughts, all day. Nothing seems worth anything. I don't care for anything" (34). In Lilith's thoughts the natural element of the maternal is inverted to one of consumption. The association of the earth too with the mother figure necessarily equates Lilith (and Adela) with the image of the dying child.

In a similar way, the setting of both the inner story and the framing narrative draws parallels between the characters of Lilith and Adela. As we have mentioned, the name of the village to which Adela's home is attached, 'Purleybridge', gives a sense of isolation and marginality through the meanings of its two constituent parts. Furthermore, as Laurence Talairach-Vielmas argues, 'The Swanspond' (Adela's house) is "redolent of the swan-maiden tales of folklore," aligning Adela "with other Undines, Melusinas, and Lamias. It thus brings into play issues of female power and sexuality and potentially questions women's lack of freedom" (Talairach-Vielmas, 36).

In 'The Cruel Painter,' the description of Lilith's house serves as an architectural metaphor for the character(s). Karl describes it thus:

Her home had a dreary, desolate aspect. It looked as if no one ever went out or in. It was like a place on which decay had fallen because there was no indwelling spirit. The mud of years was baked upon its door, and no faces looked out of its dusty windows. (349)

Scott McLaren identifies the house with Lilith's father, the painter, and his moral decrepitude. It may also be an architectural metaphor for Lilith's own soul, noting that it is specifically described as "her home" (italics mine). And as a symbol for Lilith's own inner life, it functions in a similar way to that of Adela, most specifically in reference to the absence of any "indwelling spirit" (this becomes even more significant in light of Karl's later action as a form of ghost).

The character of Teufelsburst, Lilith's father, has already been described as the villain of the story, but he is, as was mentioned above, also for a time its victim. His redemption and subsequent joy in family is the real triumph of the story, more so, perhaps than the romance between Karl and Lilith. In both Lilith and her father, the discovery of empathetic feelings is the ultimate transformative power, and in this 
way they can be read in parallel. In many ways the painter's inner workings are given more attention than his daughter's, but at the same time each character's experience sheds light on that of the other.

It is interesting to note the ways in which the nature of the evil elaborated on in 'The Cruel Painter' relates to the concept of the individual and to divinity. The narrator explains Teufelsburst's paintings and their horrific depictions of human suffering thus:

[T] he whole of the execution bore witness to the fact that upon the original beauty the painter had directed the artillery of anguish, to bring down the sky-soaring heights of its divinity to the level of a hated existence. [...] It was the suffering, rather than his pencil, that wrought the change. The latter was the willing instrument to record what the imagination conceived with a cruelty composed enough to be correct. (350)

Divine beauty is brought down to the level of a "hated existence" by the painter's art. But it is the nature of the subject as wicked, rather than the instrument by which it is created, which "wrought[s] the change" from beauty to pain. The artist's pencil is merely an instrument, albeit a "willing one," which records what the imagination conceives. And it is then from the imagination that what is ultimately an evil stems. Teufelsburst paints horrific images because "amidst a thousand distastes, it was a pleasant thing to reproduce on the canvas the forms he beheld around him, modifying them to express the prevailing feelings of his own mind" (355).

What is described in the above passage is the inverse of the eighteenth stanza of Cowley's poem, 'Hymn: to Light':

All the World[']s bravery that delights our Eyes Is but thy serv'ral Liveries, Thou the Rich Dye on them bestowest Thy nimble Pencil Paints this Landskape as thou go'st. (69-72)

"Thou" in this poem is the goddess, Light, who paints the "World[']s bravery" as well as the landscape. Teufelsburst, rather than painting bravery, paints suffering and pain, reducing divine beauty to a "hated existence." He epitomises, therefore, the opposite of light; Teufelsburst is dark, and all that which is associated with that quality. In Cowley's poem this amounts to "painted" (or false) dreams, involving "guilty Serpents, and obscener Beasts." It is significant, therefore, that the creature 
haunting the margins of MacDonald's story is the vampire, and Teufelsburst's obsession with the myth is central to the narrative.

References to the individual mind, and its physical home, the brain, are in frequent use throughout Adela Cathcart, and specifically here, in 'The Cruel Painter.' I would like to isolate a rather lengthy passage for the purposes of illustrating this in more detail. The passage gives access to Lilith's thoughts, this time involving her thoughts of Karl and the possibility of loving him:

It would not come when she called it; but when her thoughts left knocking at the door of the lost and wandered away, out came the pale, troubled, silent face again, gathering itself up from some unknown in her world of fantasy, and once more, when she tried to steady it by the fixedness of her own regard, fading back into the mist. So the phantom of the dead drew near and wooed, as the living had never dared. What if there were any good in loving? What if men and women did not die all out, but some dim shade of each, like that pale, mind-ghost of Wolkenlicht, floated through the eternal vapours of chaos? And what if they might sometimes cross each other's path, meet, know that they met, love on? Would not that revive the withered memory, fix the fleeting ghost, give a new habitation, a body even, to the poor, unhoused wanderers, frozen by the eternal frosts, no longer thinking beings but thoughts wandering through the brain of the 'Melancholy Mass.' (363)

This passage highlights the distinction between the mind and the body, the inner and the outer person. It attempts to describe the world of the inner self with images of uncertainty and confusion: "door of the lost," "mist," "some unknown," "world of fantasy." The metaphors are then extended to the outside world, where the "fleeting ghost" of a soul separated from its body takes the place of the "mind-ghost," a memory of one gone. Ghosts become the world's memory floating in "the eternal vapours of chaos" and the "Melancholy Mass." This "Melancholy Mass" comes from the first stanza of Abraham Cowley's 'Hymn: to Light,' where it forms the chaos from which the goddess, Light, is born. The leap in metaphor (from a chaos which gives birth to one which houses the dead) is made by the notion of death, but also through the figure of the vampire.

The vampire is the inverse form of the described ghost: an animated body uninhabited by a soul. This figure gives us insight into Lilith's (and by extension, Adela's) thoughts. Initially, both characters fear death, having no faith in the soul or 
eternal life. In each case, this fear can be linked to the loss of the mother. The results are unhappiness, hopelessness, and an inability to love. For Lilith, it is the supposed death of Karl Wolkenlicht and the sudden realisation that she could have loved him, that brings about the change. For Adela, it is listening to the story of Lilith and applying it to her own condition. It is the thought that the soul might be independent of death, might go on 'living' as it were, and "love on" that opens each to the possibility of love for themselves. It is the acknowledgement of a division between the body and the soul that allows this. Once she has realised this, Lilith is able to see through the vampire myth, the idea that the body can exist where the soul does not, and contemplate its opposite, eternal life. And this is where Cowley's poem comes into play again. Cowley's "Light" is the means by which the "Night, and her ugly Subjects" are defeated, including "guilty Serpents, and obscener Beasts." In this category we might place the vampire as a symbol of Lilith's lack of faith, a "painted dream" from which she awakes when she contemplates selfless love.

When Lilith wakes from her "troubled slumber" to find Karl standing over her bed, we recall the return of Ceyx's body to his wife, Alcyone, after he has died at sea. ${ }^{51}$ In Ovid's story, the goddess Juno bids Morpheus, “the feigner of man's shape," to enter the dead body of the king, and allow it to appear one last time to Alcyone, to explain his death (XI: 736). Alcyone then kills herself in grief. But rather than an explanation of his death and a declaration of ongoing love, as Ceyx gives Alcyone (a painted dream, but one which speaks the truth), we have no words at all in the interaction between Karl and Lilith. Rather, the apparition itself, through its very presence, speaks the truth: Karl is not actually dead. And rather than killing herself, this is the moment at which Lilith contemplates the possibility of an independent soul and eternal life.

The story's interest in the inner self is further portrayed by the emphasis on the inner workings of the brain. When Teufelsburst wants to increase Karl's suffering in his love for Lilith, for example, he gives him a drug which exercises "specific actions upon the brain," working on "those portions of it which are

\footnotetext{
${ }^{51}$ This story is also part of a wider collection of stories - not only is it to be found in Ovid's Metamorphoses, but it is also later present in John Gower's Confessio Amantis ("The Lover's Confession" c1390)
} 
principally under the rule of the imagination" (357). The process at stake is elaborated on at length:

By the reaction of the brain, during the operation of these stimulants, the imagination is filled with suggestions and images. The nature of these is determined by the prevailing mood of the time. They are such as the imagination would produce of itself; but increased in number and intensity. (357)

Teufelsburst's frustration is that the suffering inflicted on Karl by these ministrations is contained within his head; Karl manages to control any external sign and thus Teufelsburst's plan to make use of the experience for his art is thwarted. The situation again highlights the distinction enforced throughout the story between the inner and the outer life of the individual. The inner is inaccessible to observation from the world without. When Teufelsburst thinks that he has killed Karl, "[t]he gnomes of terror, deep hidden in the caverns of Teufelsburst's nature, broke out jubilant" (364). You almost expect the word to be "brain" here, rather than "nature", as the spatial metaphor is so similar to those used previously. The mind is frequently described as a physical place, found in the brain but made up of tunnels and caves. ${ }^{52}$ This spatial awareness helps us to focus our discussion of the enforced dichotomy between the inner and the outer self. Furthermore, not only does Lilith believe Karl to be a ghost, but Karl himself (at first) believes it also: "the fumes of the last drug of which he had partaken, still hovering in his brain, combined with these thoughts and fancies [of Lilith and of the vampire haunting the neighbourhood]" (365).

At the start of the story, Lilith and her father are portrayed in a similar way, with the emphasis on their apathetic sense of humanity. This is further clarified by their participation in Teufelsburst's painting: he as the artist, she as the model. When it appears to both of them that Karl is dead, they are affected in a similar way: the figure of Karl, lying inert beneath the velvet pall, arises "to haunt the hollow caves and cells of [Lilith's] living brain," and she lies "dreaming, and dreadful dreams. [...] Utter darkness followed, a darkness that seemed to enter into her very brain" (366). Similarly for Teufelsburst, "the phantom in the cellars of [his] imagination" will not "lie quiet" $(363,372)$. Both Lilith and her father are

\footnotetext{
52 This description recalls the spatial imagery of Phantastes and discussed in the previous chapter, as Anodos wanders underground in search of the white lady.
} 
"haunted" by Karl: just as he goes on to haunt their house by pretending to be a vampire, so too does he haunt their minds. The haunting experience is used literally and metaphorically almost interchangeably: "the thing [Karl's corpse] down there would not lie quiet, - at least its phantom in the cellars of their imagination would not." The imagination is explicitly described in the same terms as the house itself, having a cellar in which exists a haunting presence. Furthermore, both Lilith and her father are again described here in similar terms. Complete disassociation is not yet achieved.

This relationship between the two characters changes after the 'death' of Karl, however, as "[Lilith] seemed in some new way divided [from her father] by the new feeling in which he did not, and could not, share" (363). What is dividing the two characters from each other is a "feeling," an internal state. Where previously, the two characters were curiously linked, through the element of painting, and the metaphor of their house, as the story moves towards its close, and its message for Adela is emphasised, the internal state as individual and precious is once more highlighted. In separating herself from her father, Lilith is able to see beyond both her and him and recognise Karl. In the same way, Adela is able to separate herself from her father, through the development of feeling, and to recognise Harry Armstrong as a potential love interest.

While for Lilith the haunting ends when she discovers the truth about Karl, for her father the issue is more complicated. Instead of discovering that the whole thing has been a hoax, he is instead convinced that it was all in his head:

Reassured, he soon persuaded himself that the spectre in this case had been the offspring of his own terror-haunted brain. But he had no spirit for painting now. He wandered about the house, himself haunting it like a restless ghost. (375)

The crucial point is, of course, that the opposite is true. The haunting was not in fact in his head, but it is this thought which enables Teufelsburst to redeem himself. The truth for the painter is psychological. MacDonald sums up the story thus: "[Teufelsburst] was at last perfectly satisfied that things had been going on all right everywhere but in his inner man; and in this conclusion he certainly was not far wrong in more senses than one" (378). 


\section{The self as "demon-foe"}

Like Teufelsburst, it is in Adela's "inner man" (as it were!) where things have been going wrong for her. Her inwardness and constant focus on self is what has led to her illness and depression. Adela Cathcart, however, is not the only place in which MacDonald works with this idea of morbid introspection. In his Unspoken Sermons, he explores the dynamics of the relationships an individual may have both with other people and with themselves. He returns again and again to the idea that what he defines as "the self" is dangerous, and without interaction with other people it can become a "dungeon" or "demon-foe.",53 In his 1867 sermon entitled 'Love Thy Neighbour', MacDonald writes that love for others "is the only door out of the dungeon of self," and that to be trapped in this dungeon, to be too concerned with the self over the concerns of others, is to be in the act of "blowing our own breath in our nostrils" (82). This image of course suggests the creation of Man as recounted in the book of Genesis, when God has just created Adam and "breathed into his nostrils the breath of life; and the man became a living being" (Genesis 2:7). Blowing one's own breath into one's nostrils, therefore, must signify the opposite notion: rather than a divinely-inspired living being, the inhabitant of the "dungeon of self' is in a state of death. MacDonald's sermon continues:

God, his friends, his neighbours, his brothers all, is the wide world in which alone his spirit can find room. Himself is his dungeon. If he feels it not now, he will yet feel it one dayfeel it as a living soul would feel being prisoned in a dead body, wrapped in sevenfold cerements and buried in a stoneribbed vault. (83)

This insistence on images of imprisonment, burial, and funeral garb reinforces the notion that to focus on the self to the exclusion of other people and the world is a form of spiritual death.

Exaggerated self-contemplation is explicitly associated not only with death for MacDonald, but also with madness. In his second series of Unspoken Sermons (1885), he writes that "without the correction, the reflection, the support of other presences, being is not merely unsafe, it is a horror [...] The man who minds only

\footnotetext{
${ }^{53}$ See also Phantastes, where the protagonist Anodos comes to realise that the shadow following him is in actual fact an aspect of himself. Furthermore, this likening of the self to a dungeon recurs in MacDonald's fantasy novels in general: buildings represent the self in a number of his novels (fantastic and realistic) as in 'The Cruel Painter.'
} 
himself must at last go mad if God did not interfere" ('The Last Farthing,' 149). In Adela Cathcart it is the narrator, Adela's 'uncle,' who interferes, along of course with the doctor, but the motivation remains the same. These men, like MacDonald in his sermons, are primarily concerned with Adela's overwhelming sense of self. The treatment they develop, furthermore, is centred on this idea of other people as "the wide world in which alone [Adela's] spirit can find room."

However, as the three stories discussed above, and their effects on Adela, illustrate, a certain awareness of self is to be valued. The fact that Adela is cured by 'finding herself' within each story shows that it is this element of recognition which is the central issue. What differs between Adela's prior self-centredness, and her concluding contentment, is not only the recognition or reflection of the self in others. Adela is initially contrasted with, for example, Mrs Bloomfield, the schoolmaster's wife. Mrs Bloomfield, unlike Adela in her early portrayal, is characterised by contentment:

as if her heart were at rest; as if for her everything was right; as if she had a little room of her own, just to her mind; and there her soul sat, looking out through the muslin curtains of modest charity, upon the world that went hurrying and seething past her windows. (41)

This third 'architectural' view of the self is clearly different both from the dungeon and "stone-ribbed vault" metaphors discussed above, and from the house of Lilith with its "dusty windows" out of which no one ever looks. Yet the concept of windows does necessarily retain, and indeed valorise, a crucial and significant degree of separation between the self and the world, albeit in a positive "muslincurtain[ed]" light. Adela is cured not, as the nineteenth-century doctors would have it, by tennis or horse-back riding, or any other such activity meant to reverse the inward gaze, but rather "from within." We find ourselves thus asking the question that MacDonald's narrator puts into the mouth of his reader at the close of the novel: "do you think it was your wonderful prescription of story-telling that wrought Miss Cathcart's cure?" (420). And his reply is of course that "the cure was effected mainly from within. Except in physics, we can put nothing to the experimentum crucis, and must be content with conjecture and probability." 


\section{Chapter Three: \\ "The course of this world": childhood innocence and resisting temptation in Wilfrid Cumbermede}

The novels discussed in the previous two chapters, Phantastes and Adela Cathcart, both centre on protagonists engaging with self-discovery at that transition into adulthood that MacDonald situates at around the age of twenty-one. The exploration of mind thus far has therefore been concerned with the mental state at such a period of transition. In Chapters Four and Five the focus shifts to two of MacDonald's titular heroes who have already attained an adult sense of identity, and who use their already realised sense of self to engage with secondary characters who are somehow deficient. The subject of this chapter, MacDonald's 1872 "autobiographical story," Wilfrid Cumbermede, treats the formative nature of childhood in determining character, as its narrator-protagonist (Wilfrid) recalls his child- and early-adulthood. During this period, Wilfrid makes the almost-fairytale discovery that he is the legal heir to the ancient estate (Moldwarp Hall), next to which he has lived nearly his whole life, and the title that goes along with it. MacDonald's representation of individual development in the novel is paradoxical. At one level, the novel, with its detective-story plot and bildungsroman form, implies the importance of memory and history in the necessary acquisition of knowledge. But, as we shall see, it also idealises childlike innocence and ignorance, setting up these qualities as a foil to the pursuit of worldly wisdom. The interest in the mind, therefore, emerges in the consideration of self-knowledge.

Knowledge as negative and potentially dangerous comes across most clearly in the novel in its contrast with childhood innocence/ignorance. At the start of the novel, the older Wilfrid narrating the story describes his younger self as disinterested, even fearful, of any knowledge beyond his already existing and comfortable awareness. Thus he describes himself as having been unwilling to explore unfamiliar territory: 
I had not yet explored the boundaries of the prairie-like level on which I found myself. As soon as I got about a certain distance from home, I always turned and ran back. Fear is sometimes the first recognition of freedom. Delighting in liberty, I yet shrunk from the unknown spaces around me, and rushed back to the shelter of the home walls. (31-2) Wilfrid's reluctance to find out anything beyond what is immediately available to him is explicitly a childish tendency. Furthermore, any incipient transition out of this state is accompanied by an intensification of this 'fear of the unknown,' by a real sense of danger. Wilfrid finds a pendulum amongst his great-grandfather's old things, but, just as he was reluctant to explore his physical surroundings, he avoids using it, "partly from a dim dread of exercising power whose source and extent were not within my knowledge" (11). When he does decide to use it, his decision is based on his sense that he is too grown-up to be afraid:

I bethought myself. I was nearly a man now; I would be afraid of things no more [...] Not this time would I flinch from what consequences might follow - let them be what they might. (20-21)

A movement from childhood, then, is seen not only as permitting a new interest in the acquisition of knowledge, but as a conquering of fear in order to gain that knowledge.

Fear has a significant role in the novel, particularly in relation to this idea of liberty. The swinging of the pendulum without restriction, however, brings with it (or so it seems to Wilfrid) not only a fierce storm, but also the lawyer $\mathrm{Mr}$ Coningham (the name as novel is significant), and the first real threat to Wilfrid's idyllic life at the Moat:

Out of the darkness... as if blown thither by the wind, rushed a figure on horseback, his large cloak flying out before him, and the mane of the animal he rode streaming out over his ears in the fierceness of the blast. He pulled up right under my window, and I thought he looked up and made threatening gestures at me... I shrank back, and when I peeped out again he was gone...I crept back to my bed in a new terror, for might not this be the Prince of the Power of the Air, come to see who was meddling with his affairs?" (26)

The "Prince of the Power of the Air" is of course the Satan of Ephesians 2:1-3, described by Paul in his warning against the dangers of 'this world': 
Wherein time past ye walked according to the course of this world, according to the prince of the power of the air, the spirit that now walketh in the children of disobedience. Among whom also we all had our conversation in times past in the lusts of our flesh, fulfilling the desires of the flesh and of the mind, and were by nature the children of wrath. $(K J V)$

Mr Coningham, as a lawyer attempting to persuade Wilfrid's uncle to take up a suit against the Brothertons with the goal of succeeding to their property, is clearly a suitable stand-in for the demonic promoter of "the course of this world" and the "desires of the mind." It is at this moment that the notion of knowledge as a negative acquisition becomes particularly associated not only with a movement out of childhood, but with avarice and the knowledge of worldly influences.

Childhood ignorance is correlated with the state of grace by a significant allusion to Genesis 3, which tells how Eve (and subsequently Adam), tempted by Satan in the form of a serpent, came to eat the fruit of the knowledge of good and evil (traditionally an apple) forbidden to herself (and Adam) by God. While exploring the countryside around the village where he is at school, Wilfrid sees an apple hanging from a branch protruding over the wall of what he assumes must be a kitchen garden. While it remains hanging from the branch his moral position is clear, but when it falls to the ground right at his feet, his own "fall" is imminent:

An apple must fall sometime, and for this apple that some time was then. It lay at my feet. I lifted it and stood gazing at it - I need not say with admiration. My mind fell aworking. The adversary was there, and the angel too. (61)

The apple belongs to the estate to which Wilfrid is - although he does not yet know this - the rightful heir. Having picked up and bitten the apple, Wilfrid is immediately remorseful, and he seeks out the owner to apologise. Upon meeting Sir Giles, and being shown and made welcome on the estate, Wilfrid's imagination is immediately captured by its size and historical grandeur; his ongoing interest in the place makes Mr Coningham's job of persuading him to pursue his legal entitlements that much easier.

If the apple as a symbol for the entire Moldwarp estate is not made clear enough in this first instance, it is brought again to the fore later in the novel, when 
Wilfrid is at last made fully aware of his legal claim, and is about to accept what Coningham offers:

'Then the apple was my own, after all!' I said to myself exultingly. It was a strange fantastic birth of conscience and memory - forgotten the same moment, and followed by an electric flash - not of hope, not of delight, not of pride, but of pure revenge. (408)

Associating the moment not with any positive emotion such as "hope" or "delight," but with "pure revenge," MacDonald represents Wilfrid's claiming of the apple (even though it belongs to him) as a sin, a symbol of worldly desire.

If in the paradisal garden of Wilfrid's childhood, Mr Coningham plays the role of "the tempter," through his offer of the gift of knowledge, then Wilfrid's uncle plays that of the divine Father, in his attempt to keep him ignorant. So, for example, he himself refuses to pursue the lawsuit, and when he hears that Wilfrid has been to the Hall and met Sir Giles, he sends him away to school in Switzerland in an attempt to forestall any influence further such meetings might have on him. Wilfrid's uncle's name is David - but David Cumbermede is unlike his Biblical namesake. While King David exploited his position of power (placing Uriah the Hittite in the front line of battle where he would be killed, in order to escape the repercussions of Bathsheba's pregnancy), Wilfrid's uncle has chosen to renounce his capacity to achieve selfish and worldly ends. This highlights the choice that lies before Wilfrid. He must choose either a life of worldly wealth and social influence as advocated by Coningham, or one of quiet self-dependence as modelled by his uncle.

For MacDonald, and by extension his reader, the choice is clear: the biblical imagery ensures this. Wilfrid's childhood perception of Coningham as the "prince of the power of the air" (and also as an ape-faced demon with telling "magpie" eyes, 79 ) is an impression which lessens in intensity over the duration of their relationship until they become at one point almost friends. But it is given new validation near the close of the story, with the revelation of Coningham's purely mercenary motives. When he discovers that Wilfrid has no intention of pursuing his fortune, at least not while old Sir Giles remains alive, Mr Coningham is once again transformed in Wilfrid's eyes into a demonic figure:

He turned on me with a sneer. His eyes had receded in his head, and in his rage he grinned. The old ape-face, which 
had lurked in my memory ever since the first time I saw him, came out so plainly that I started: the child had read his face aright! the following judgement of the man had been wrong! the child's fear had not imprinted a false eidolon upon the growing brain. (502)

Thus Wilfrid's initial childish fear and distrust of this follower of "the course of this world," is justified in the final pages, with his decision not to pursue his worldly ambitious dreams. The value of childhood innocence is upheld.

Wilfrid's progression, however, from a state of childhood ignorance to one of knowledge and worldly desire does in many ways turn out to be one of necessity. He could not have remained in ignorance, as his uncle had seemed to wish, and still have made the 'right' decision concerning his inheritance. While for a number of MacDonald's fantasy characters (Diamond, for example, in At the Back of the North Wind) to remain a child is to be qualified for entry into the kingdom of heaven, Wilfrid Cumbermede is not a fantasy, and so such a resolution is not possible.

Despite its idealisation of innocence, Wilfrid Cumbermede does in fact portray the acquisition of knowledge as a positive and necessary process.

Firstly, the overall narrative follows the style of the detective novel, whereby the bringing to light of information is crucial to plot development. A number of plot devices in the narrative contribute to the centrality of the theme of 'finding out': various clues are set up, taking the form of significant objects, which then provide a link between Wilfrid's childhood home of the Moat, and Moldwarp Hall. In the kitchen of the Moat, for example, hangs a piece of tapestry, which we later discover was cut from a much larger one in one of Moldwarp's many bedchambers. Its initial description highlights its fragmentary nature, positing the need to put it once again in its wider context: "[i]t would have required a very capable constructiveness indeed to supply the design from what remained, so fragmentary were the forms, and so dim and faded were the once bright colours" (8-9). Similarly Wilfrid's sword, which also once hung on the wall of the Moat's kitchen, comes to symbolise the mystery of his origins: "That sword was to my childish eyes the type of all mystery, a clouded glory, which for many long years I never dreamed of attempting to unveil” (9). When he does eventually begin to "unveil" the mystery, he finds that it originally came from Moldwarp's armoury, and a full description of it is to be found there amongst the records. Finally, in a similar invocation of fragmentary parts fitting within a wider whole, a book found amongst his great-grandfather's possessions is 
also found to have originally belonged in the Moldwarp library. These significant objects, and their function as "broken links indicat[ing] some former connection between the Moat and the Hall" (339), help sustain the overall narrative structure of the novel.

If we look at the significance of names in the novel, we can see a similar trend. The protagonist's own name becomes significant in light of this idea of the novel as detective story. 'Wilfrid', derived from the Old English, means "desiring peace," a definition significant in light of the restorative function of the main character's actions. Working against this, however, is the more complex connotation behind his surname: the $O E D$ gives one meaning of "cumber" as "to confound or trouble the mind or senses; to perplex, puzzle" (cumber, v. 2. b.), a fitting description of Wilfrid faced with the mystery of his family history. But its more familiar meaning is of course "that which cumbers, incommodes, hinders" (cumber, $n$. 3. a.). "Mede," as being property in the form of land, or meadows, becomes in this case one which is burdensome (cumbersome) and must be abandoned. Once Wilfrid has pieced together his ancestry, furthermore, he finds himself with a new and perhaps less troublesome name: Wilfrid Cumbermede Daryll, 'Daryll' being a name similar in meaning to his uncle's: "beloved." "Moldwarp," as the name of the estate to which Wilfrid is entitled, is also suggestive. The $O E D$ defines the word firstly as referring to "the European mole" (moldwarp, $n$. 1.), an animal known a) for its blindness, and b) for its habit of digging underground, both characteristics sharing significance with our subject, concerned as it is with the concealing and uncovering of secrets, and indeed with Wilfrid himself as he tries to uncover information about himself. But the $O E D$ 's second definition is perhaps even more interesting, being "an underhand person; a sneak, a plotter, a spy" (moldwarp, n. 2.). In other words, a moldwarp is a person who uses information or knowledge for malicious ends and purposes, not unlike Geoffrey Brotherton in his attempt to sabotage the wedding register and only record of the marriage of Wilfrid's great-grandparents (399). MacDonald's use of names, therefore, is clearly reinforcing an atmosphere of mystery and suspense in the novel.

The text itself, as a novel about the search of an individual for information about his past, along with its explicit use of a first person narrator, an older version

\footnotetext{
${ }^{54}$ The name 'Wilfrid', deriving from Old English, means "desiring peace."
} 
of the young Wilfrid whose story it is we are concerned with, necessarily shows this; inherent in its very structure is the need to pass on story. It is a classic bildungsroman, a narrative that (as Abrams has defined it) follows "the development of the protagonist's mind and character, in the passage from childhood through varied experiences - and often through a spiritual crisis - into maturity, which usually involves recognition of one's identity and role in the world" (201). A childhood state of ignorance cannot be sustained or celebrated within the confines of this genre.

The narrator's constant appeal to memory as a means of validating his story as truth is a further means by which the acquisition of information in the novel is a necessarily positive experience. The older Wilfrid's need to justify his story through the confirmation provided by personal memory shows us that it is the aspect of truthfulness that lies behind his need to pass it on:

So much does my past wear to me now the look of something read in a story, that I am haunted with a doubt whether I may not have communicated too much of this appearance to my description of it, although I have kept as true as my recollections would enable me. The outlines must be correct: if the colouring be unreal, it is because of the haze which hangs about the memories of the time. (191)

This is just one of several instances where the narrator assures us that what he tells is based on fact. Further to the above-mentioned status of the novel as a bildungsroman, a coming of age story, this justification of the transmission of truthful story is associated with age. Our narrator is careful to assure us in the opening pages that he is "I will not say how old, but well past middle age," and that "no man should attempt a history of himself until he has set foot upon the border land where the past and the future begin to blend in a consciousness somewhat independent of both, and hence interpreting both" (1). Furthermore, it is not only our narrator's own age and memory that is appealed to in the argument for the importance of passing on knowledge through story, but also that of his greatgrandmother. ${ }^{55}$ When Wilfrid goes to visit her as a child, she tells him that she cannot die, that "until I have done what I have to do, the grave that is waiting for me will not open its mouth to receive me" (18). And what she must do of course is tell

\footnotetext{
${ }^{55}$ And any reader of MacDonald knows that a great-grandmother figure, especially one who lives at the top of a winding stair, must be paid attention to.
} 
Wilfrid the story of her marriage to his great-grandfather, the Wilfrid Cumbermede for whom he was named, and the very story which goes on to become the impetus behind that which we are reading ourselves.

So while knowledge, in so far as it leads to worldly temptation, is clearly presented to us as a loss of innocence, the idea of (his)story as Truth manages to succeed it. Wilfrid's decision at the end of the book to delay action until the death of the Brothertons, furthermore, and the fact that the novel ultimately fails to supply us with a conclusive ending on this account, places a moral value on what he has learnt. For MacDonald, there is clearly a 'proper' use for knowledge, in the light of which one can still retain an innocence akin to that of childhood. For an explanation of this we can perhaps turn to Milton's Areopagitica, in which the author argues against the enforced licensing of printing in 1644. Milton too makes use of the imagery of the Fall, arguing that "It was from out the rind of one apple tasted, that the knowledge of good and evil, as two twins cleaving together, leaped forth into the world. And perhaps this is that doom which Adam fell into of knowing good and evil, that is to say of knowing good by evil" (20). In Wilfrid Cumbermede, MacDonald too is recognising this necessity - that while childish ignorance must by our very natures be lost, knowledge is given us that we, like Spenser's Guyon being brought through "the cave of Mammon" and "the bower of earthly bliss," might "see and know, and yet abstain" (Milton 13). 


\section{Chapter Four:}

\section{"A tortured mind": madness in Malcolm}

\section{Introduction}

One of MacDonald's most successful novels during his lifetime, Malcolm was first published in 1875, and was followed soon after by its (equally successful) sequel, The Marquis of Lossie (1877). As was Wilfrid Cumbermede, Malcolm is the story of a young man, the titular hero, who discovers that his actual personal history does not in fact align with that account of his birth which he has been brought up to believe. $\mathrm{He}$ is in fact the son of a marquis, who was himself tricked into believing that his first wife, Malcolm's mother, had died, and who was not aware that she had given birth to a son. Set in Portlossie, a fictional version of Cullen, on the north coast of Scotland, the novel fits in with the author's other Scottish works and invokes a strong sense of place. MacDonald's return to this familiar landscape of Aberdeenshire where he grew up gives his prose here a strength and surety recognised by contemporary readers as well as critics today. Malcolm was serialised in The Glasgow Herald, and proved both popular and, more importantly, lucrative for its author, described as it is by William Raeper as “one of [MacDonald's] most readable and exciting novels" $(1987,334)$. In terms of critical approaches to the novel, that of David S. Robb - to which I shall return - proves the most sustained.

Despite the novel's popularity at the time it was published, and the recognition of this by critics of the late-twentieth and early-twenty-first centuries, discussion of the novel has tended towards bland generality. William Raeper, for example, in his biography of the author, George MacDonald (1987), discusses Malcolm primarily in terms of comparison with the author's other novels, focussing on its revelation of the author's key strategies: didacticism, through frequent asides to the reader and use of "schools and schoolmasters" (195); a "thirst for accuracy" (190), in the vivid picture drawn of Cullen and its inhabitants, and inclusion of historical events such as the Banffshire religious revival; and its villain Mrs Stewart as a precursor for the titular character of the more (critically) popular Lilith (1895). Despite the rather shallow nature of the criticism, scholars have in general remained 
positive about the novel's qualities. Elizabeth Saintsbury, furthermore, describes the characters in the novel, particularly those of the hero and his grandfather, the blind piper, as "some of the most convincing in all his books" (116).

In George MacDonald (his contribution to the Scottish Writers Series), David S. Robb locates the novel along a spectrum of the author's use of what he terms "the Christ-principle" (1987, 32). According to Robb, the Portlossie novels (Malcolm and The Marquis of Lossie) are "the finest and clearest examples" of a phase in MacDonald's writing in which the triumph of the "Christ-principle" is located beyond internal growth of a character, as it was in his earlier novels, and is instead to be found in "the eventual establishment in a position of social authority" (32). According to Robb, Malcolm, along with The Marquis of Lossie, constitutes "MacDonald's most extended and elaborate allegory of Christ's triumph" (67), as the author "breathes life" into the standard romance plot of the lost heir recovering his birthright. Malcolm's eventual rise to become the Marquis of Lossie thus represents "the instinct within men to reattain their heavenly birthright" (67). Rather than a tale of the young hero becoming Christ-like within the bounds of the bildungsroman, as can be seen, for example in the journey of Anodos in Phantastes, or that of the eponymous hero of Wilfrid Cumbermede, the Christ element in Malcolm is clearly present and visible within its titular hero right from the beginning. Robb also discusses the novel in terms of its presentation of good and evil, granting evil a rare value and significance, as something not just to be defeated, but to be countered in a perpetual cycle. Evil, Robb claims, has the initiative in this novel, and so "the tale is of the good characters fending off various assaults on their welfare and integrity" (71).

In his analysis of the text in terms of the "Christ-principle," Robb locates the various characters within "a confrontation of opposites" (70). While Malcolm himself is seen as a representation of Christ, other characters are identified by Robb as facets or embodiments of "Humanity" (72). Examples of these include Malcolm's father, the marquis, whose loss of his first wife, Malcolm's mother, and subsequent somewhat depraved behaviour marks him as "the erring parent of the Son of Man" (72); and Duncan MacPhail, the blind piper who found Malcolm as an infant and raised him as his own grandson. Duncan is described by Robb as "that in Humanity which loves and nurtures the child-like Christ within us all" (73). The most interesting example, however, is that of Stephen Stewart, laird of Gersefell, whom 
Robb sees as "a pathetically limited, twisted, vulnerable falling-off from the ideal creature God envisaged" (73). His characterisation in the novel as "mad," but also as a sort of visionary, however, is such that limiting him to a mere symbol of humanity's failure to attain God's perfection is a dramatic under-reading of his character's status within the text.

For the rest of this chapter, I shall be building upon Robb's reading of the laird. As I see him, however, the laird is important not only for his own sake, but as an analogue illuminating the hero - and the novel as a whole. My argument, in brief, is as follows: Malcolm MacPhail appears initially comfortable with the belief that he is an orphan, and that the old town-piper, Duncan MacPhail, is his grandfather. But (as we shall see) Malcolm is like the mad laird, Stephen Stewart, who draws attention to the question of origins with his catch-phrase, "I dinna ken whaur I come frae," while his disabilities (which are mental as well as physical) present an image of a fractured self. The laird's mother, Mrs Stewart, claims Malcolm as her son, thus connecting him with the mad man, and Malcolm does come to identify with the laird's sorrow. Parentage and family history turn out to be as central here as they are in Shakespeare's great family tragedy, King Lear. In Shakespeare's play, too, madness and its necessary feature of isolation becomes inextricably caught up in the question of humanity. Lear's lament on the stormy heath, that "unaccommodated man is no more but such a poor bare, / forked animal" (3.4.106-7), translates for MacDonald into the laird's lonely, wild existence outside the civilising bounds of human society. Isolation in its varying forms as an accommodating feature of madness is not uncommon to MacDonald's writing. Diamond, the child protagonist of At the Back of the North Wind (1871), is a character ostensibly defined by his discernable difference from his London slum surroundings, and this difference is frequently characterised by references to lunacy, including recurrent mentions of mental asylums. The tension established between freedom and confinement is even more apparent, however, in Malcolm, where it functions as a central plot and character device; and while the lunatic asylum in its physical sense never makes it beyond the borders of the novel, the threat of what it represents remains a significant force. 


\section{Contextualising madness}

The history of madness and its place in society is a field fraught with conflict and contradiction. According to social historian and theorist Michel Foucault's "great confinement" model, it was the royal edict in France of April 27, 1656, prescribing the creation of an hopital general in every city, which can serve as a landmark for the connection made between madness and "the country of confinement" (Madness and Civilisation 39). Foucault argues that establishments such as the hopital general were not medical establishments, but rather a means of creating and maintaining social order, and that the insane were grouped with other such threatening classes as the poor, the criminal, and the unemployed (39). Roy Porter suggests that while Foucault's identification of 'Reason' and society as forces conspiring to "control and silence madness" is no more sophisticated than the more traditional tales of the history of psychiatry, it deserves recognition as a building block for later studies of madness as "a particular mode of disease representation" (Porter 2003, 4).

Sociologist Andrew Scull argues that, according to the more general view of the "Chain of Life," where human beings fitted on a continuum alongside other living creatures, for much of the eighteenth century the mad were treated as sub-human (Scull 109). The lunatic was viewed as "brutish" and was thus treated as such. With the turn of the century, however, Scull continues, came the growing opinion that rather than being akin to beasts, the mad were to be treated instead as human beings, but such as having become disconnected with their moral and rational selves. They were therefore to be treated in such terms by an appeal to the moral sense without resort to physical constraint or punishment.

This new "moral treatment" was pioneered in England by William Tuke, in his asylum, York Retreat. Moral treatment was followed by reform of the asylum, the architecture of which was regarded as crucial (Scull 1). But there were critics of the asylum method of treatment, who were concerned that rather than treating the insane, asylums, like the hôpital general of seventeenth-century France, were instead merely containing them in order to keep them out of the way of everyday society. Still other historians have argued that the situation was far more complex. The asylum, it was argued was a "contested site" (Porter 4), not controlled completely by either the medical or psychiatric profession or the state. It was, furthermore, "neither 
a site for care and cure, nor just a convenient place for locking up inconvenient people" (4). In fact it was "many things at once." This has been attributed to the complexities of the different relationships between the different parties involved: not only doctors and patients, but their families also. Scholars such as A. Suzuki give precedence to the power of the family in determining forms of treatment for "difficult relative[s]" (195). Elaine Murphy also argues that the placement of individuals within such institutions as the asylum, "is now regarded more the outcome of contractual and bargaining negotiations between family, poor-law officials and doctors, between the 'community' and 'authority,' than an imposed medical solution" (336).

With such regard of institutionalization, there were also significant fears of wrongful detainment, especially among the middle and upper classes where fiscal issues of inheritance and succession were crucial. Private institutions, where those of the upper echelons were generally housed, relied on the funds generated by their inmates. Family members and estates funded these institutions unlike the statefunded public asylums. Newspapers of the time printed stories of wealthy landowners wrongfully committed by greedy relatives, with the help of equally greedy medical men, eager for the fees awarded by asylums for successful committal. ${ }^{56}$ This was treated in popular fiction, such as Henry Cockton's Valentine Vox (1840) and Charles Reade's Hard Cash (1863). George MacDonald, too, embraces the issue of lunacy in terms of its perception and treatment by society. As previously mentioned, the condition consistently takes the form of a sense of difference in a character from the rest of society, and is accompanied by the sense of a special relationship with God.

\section{The fool for God}

According to The Dictionary of Biblical Tradition in English Literature (1992), most biblical references to the term 'fool' refer not to the literal fool (the mentally incompetent), but to the moral or wilful fool: one who is set against the wisdom of God. The character of folly, from a biblical point of view, is the person who

\footnotetext{
${ }^{56}$ A search for "lunacy" in The Times database between 1860 and 1875 revealed a number of articles primarily concerned with the wrongful accusation of lunacy against individuals of the land-owning classes, often those with slightly eccentric behaviour, for example behaving irresponsibly with regards to business transactions.
} 
consistently mistakes the tangible goods of this world for ultimate value. However, in his first letter to the Corinthians, the apostle Paul recommends the notion of becoming a fool in order to show devotion to God:

Let no man deceive himself. If any man among you seemeth to be wise in this world, let him become a fool, that he may be wise. For the wisdom of this world is foolishness with God. For it is written, He taketh the wise in their own craftiness. (1 Cr 3: 18-19)

In each case the concept of folly, or foolishness, is set against that of wisdom and highlights the distinction between the divine realm and the earthly one. The fool is either a symbol of man's wilful reliance on the material world at the expense of the spiritual, or he is one who rejects "the wisdom of this world" in favour of the divine.

Stephen Stewart (otherwise known as the mad laird) plays a similarly mediating role in MacDonald's novel. The ways in which other characters in the novel respond to his "mad" appearance and behaviour reflects Paul's prescription for the Christian, in terms of persecution and suffering at the hands of others. Paul writes in his letter, "even unto this present hour we both hunger, and thirst, and are naked, and are buffeted, and have no certain dwelling place" (1 Cor 4:11). In MacDonald's novel, the laird, too, though sporadically fed and sheltered by benevolent members of the community, has no "certain" home. He has no material possessions, except for the clothes on his back, relying for all else on the benevolence of others. What he himself seeks, furthermore (from other people and from the world in general), is utterly unrelated to the material. As will be made clear in what follows, the laird is constantly in search of his origins, while at the same time denying any relationship with his natural mother: his quest is thus given a metaphysical context. His nomadic state is a direct result of his rejection of his mother and her cruel treatment of him. Paul's letter continues, "being reviled, we bless; being persecuted, we suffer it: Being defamed, we intreat: we are made as the filth of this world, [and are] the offscouring of all things unto this day" (12-13). As we shall see, the emphasis on suffering through persecution is a defining characteristic of the laird's situation; he too is maligned and feared by those around him.

While the laird's suffering at the hands of others necessarily aligns him with the figure of the fool for God, there are significant differences between the two 
characters. The biblical fool risks the derision of the world in order to be pleasing to God. For MacDonald's character there is no such choice inherent in his affliction. In fact, part of the laird's mental distress comes from the fact that he does not know God; but the earnestness of his quest to discover where it is he comes from, and his overall innocence in the face of others' clear superiority in the subject of religious faith (specifically Mr Graham and Malcolm), makes of him a fool in the wider and more literal sense, that of the mentally incompetent. This portrayal is highlighted by the references made in the novel to contemporary attitudes toward the idiot or lunatic as experienced by the author and his own society, and leads to tensions within the character concerning the nature of his condition. These tensions take the form of a debate between the laird's condition as natural, or as the result of parental rejection and abuse, while such a division is explored through his disability as both physical and mental. The laird's condition functions in the novel, therefore, on a number of levels. Furthermore, his madness informs (and is informed by) the characterisation of others in the novel, and the multiple parallels established locate the author's interest in the mind as a site of mediation between the physical and the spiritual.

\section{Associative madness}

In Malcolm, the hero's sense of self is blurred through his relationship with the mad laird. The effect of such an association between the two characters is to implicate interpersonal relationships in the novel's portrayal of madness. This recalls another example of biblical influence on the novel: the story of David and Jonathan in the book of Samuel. While the condition of madness is also a feature of that story (and one to which I shall return), it is in the relationships between the characters that the story's relevance is most apparent: in particular the friendship between David and Jonathan, and the threat to that relationship from King Saul. As the bible story tells it, David's defeat of Goliath is followed by the similar defeat of the Philistines by the Israelites. The people of Israel sing in praise of David at the expense of Saul: "Saul hath slain his thousands, and David his ten thousands" (1 Sa 18: 7). Saul sees a threat to his kingdom in David's popularity and decides to kill him. ${ }^{57}$ An attempt is

\footnotetext{
${ }^{57}$ Saul's hatred of David is not based only on his jealousy of the younger man's popularity with the people: "Saul was afraid of David, because the LORD was with him, and was departed from Saul" (1 Sa 18: 12). In MacDonald's novel, too, the idea of a character as blessed with a special relationship with the divine is also significant. As will be discussed shortly, the laird in his madness is portrayed as spiritually superior to other characters in the novel.
} 
made by Jonathan to intercede between his father and his friend, but he is commanded by Saul to betray David: "now send and fetch [David] unto me, for he shall surely die" (20: 31). Jonathan's refusal to betray David enrages Saul, and he casts a javelin at him, convincing him that "it was determined of his father to slay David" (20: 33).

The significance of this story to MacDonald's novel can be seen in the similar situation established between Malcolm, the mad laird, and the laird's mother, Mrs Stewart. In a scene towards the middle of the novel, Malcolm visits Mrs Stewart and is asked by her to give up the location of her son so that he can be locked away: "He would trust you now," she entreats Malcolm, "your presence would keep him from being terrified" (220). Mrs Stewart's false kindness then turns to anger at Malcolm's refusal to help her:

Mrs Stewart changed colour - neither with the blush of innocence nor with the pallor of guilt, but with the gray of mingled rage and hatred. She took a step forward with the quick movement of a snake about to strike, but stopped midway, and stood looking at him with glittering eyes, teeth clenched and lips half open. (362)

Her anger and her aggressive stance mirror Saul's in his attempt to strike Jonathan with the javelin. Malcolm's loyalty to his friend, furthermore, in refusing to act as Mrs Stewart's tool, mirrors that of Jonathan's toward David. ${ }^{58}$ The reversal of roles in MacDonald's novel, the fact that it is Mrs Stewart's own son whom she attempts to capture and have shut away in a lunatic asylum, reinforces the blurred nature of the relationship between Malcolm and the laird. Mrs Stewart's claim that Malcolm too is her child, in an attempt to dissolve her own son's inheritance rights, also contributes to the mingling of their characters. The book of Samuel describes the relationship between David and Jonathan as one of souls: in their friendship, "the soul of Jonathan was knit with the soul of David, and Jonathan loved him as his own soul" (1 Sa 18:1). As we shall see, the relationship between Malcolm and the mad laird is portrayed along similar lines, connected by MacDonald's version of the soul: the self.

\footnotetext{
${ }^{58}$ Furthermore, Mrs Stewart then goes on to consult the evil Mrs Catanach, much in the same way that Saul does the witch of Endor in the bible story. Mrs Catanach is frequently referred to as a witch throughout the novel $(44,151,276)$.
} 
Before I move into further discussion of Malcolm and the mad laird, however, it is interesting to note that madness is also a feature of the above bible story. In order to escape Saul's persecution of him, David flees his court and eludes him in the wilderness. On the way, he finds himself at the court of Achish, the king of Gath. Upon the servants' recognition of him, and their labelling of him as "king of the land," David pretends to be mad: "And he changed his behaviour before them, and feigned himself mad in their hands, and scrabbled on the doors of the gate, and let his spittle fall down upon his beard" (1 Sa 21:13). While David's madness is feigned, and that of MacDonald's laird is clearly not, the description of the fit is significant, and introduces the idea of madness as having a visual quality. While physically deformed and mentally 'incompetent' throughout the novel, the laird does not show any overt signs of madness (fits such as David's described above) unless provoked by mention of his mother. Then, the parallels are uncanny, down to "the slaver rinnin' doon his lang baird" (10). The beard was a commonly described feature of the lunatic at the time, often accompanied by the adjective "wild" to describe the face and expression in general (Houston 52). In contrast to this popular notion, however, the laird's facial features are in no way consistently described as wild or mad. Quite the contrary (with the exception of his appearance during a fit), as we shall see, his features are "refined" and he carries with him a general air of quietness. This depiction reinforces MacDonald's position that the laird's condition is not to be treated under the same auspices as the insane at the time in which the novel is set (fifty years prior to its actual publication).

While clearly a rejection of the "wild" stereotype of the "mad" individual, $\mathrm{Mr}$ Stewart is nevertheless labelled as just such by the local townsfolk - hence the labelling of him throughout the novel as "the mad laird." This judgement is shown to be a result of his obvious visible disabilities in both a physical and a mental sense. The understanding of madness in the nineteenth century was often bound up with the study of physiognomy, leading to the idea that the mad "generally possessed a distinctive physiognomy separating them from the sane" (Browne, cited in Wiesenthal, 4). The laird's physical appearance is consistently referred to as deformed, and combined with the impairment of his mental function, which consists primarily in a monomania concerning his origins. The central premise of his portrayal as such distinguishes him as significantly different to the rest of his society, in "his appearance, his ways, and his speech" (12), thus highlighting once again the 
individual as a major concern for MacDonald in this novel. However, as the story develops, the disabled character and his epithet as "mad" become more complex. This complexity first emerges in the parallels alluded to between the laird and significant other characters with regard to his disability. This becomes especially apparent in the case of Malcolm himself, with his similar portrayal in terms of his individuality and depiction of one who stands out as being different to others.

The first suggestion of difference in the case of the laird is his initial depiction as "a strange figure" (7). Malcolm too, however, is also initially characterised as a figure that stands out from those around him. His "long, swinging, heavy-footed stride" is "a movement unlike that of the other men of the place" (15), and his general "form and face" are such "as would have drawn every eye in a crowded thoroughfare" (15). Similarly, it is the laird's form and means of movement which are initially drawn attention to in his description as "strange." $\mathrm{He}$ is described as "a man of dwarfish height and uncertain age, with a huge hump upon his back" (7). His unusual gait, or way of movement, is significant to his portrayal, promoting fear in the townspeople (10), and disgust in the marquis and his daughter. Terms such as "the dwarf" or the "hunchback" are used throughout the novel to refer to him, thus predominantly defining him by his physical appearance. Like Malcolm, however, he has "features of great refinement," another significant parallel between the two characters, which introduces early on the possibility of their being in fact related to each other.

Malcolm and the laird are not only connected through physical appearance, however. An underlying tension between the two characters is also suggested in their thoughts. When it is revealed to Malcolm that he too may be the son of Mrs Stewart, for example, the parallels are made explicit:

[Malcolm's] thoughts turned to the new darkness let in upon his history and prospects. All at once the cry of the mad laird rang in his mind's ear: "I dinna ken whaur I cam frae!" (263)

The repetition of the laird's catch-phrase in the portrayal of Malcolm's own state of mind, ringing as it does "in his mind's ear," ties the two characters together in terms of identity. The image of "new darkness" breaking in upon his sense of identity reflects the laird's similar lack of clarity concerning his origins. 


\section{Madness in mind and body}

Right from the initial portrayal of the laird the connection between the physical body and the processes of thought or the mental state is established. Mrs Catanach, a character depicted from the start of the novel as appearing "to the first glance $[\ldots]$ kindly, to the second, cunning, and to the third, evil" (4), is the first character with whom we witness the laird in interaction. Mr Stewart comes across her gazing out to sea, her posture masking the "revolving" of "something in her unwholesome mind," an "operation which naturally would have been performed with downbent head and eyes on the ground" (7). Such malevolence of thought works to define her character throughout the novel. The laird upon meeting the woman mimics her posture, "gaz[ing] up at her countenance as intently as she seemed to be gazing on the sea" (7) - the repetition of the term "gaze" or its variations (gazed, gazing etc...) in the passage draw attention to the significance of the pose in terms of each character. Gazing as musing in the character of Mrs Catanach is thus carried over into the parallel portrayal of the laird. We are compelled to consider the laird's thoughts, and are soon provided with these in an ensuing conversation concerning origins. The laird declares in what is to become his "catchphrase" throughout the text, "I dinna ken whaur I come frae" (8). A striking connection between the laird's mind and his body has thus become apparent in this first interaction, where it is hinted at in the description of his eyes. The fact that they are "mingled with a certain mottled milky gleam" (7) suggests a lack of clarity also in his thoughts, the common idea that the eyes are the windows to the soul, or a way in which a person can read another's thoughts.

The laird's mental peculiarities consist primarily in his obsession with his origins, and his fear of his natural mother. His rejection of his mother can be equated with a denial of the earthly aspect of his heritage, as Robb has argued. His stammer, which means that he is unable to articulate what is in his mind, gives the impression that his mind itself is disordered. It is difficult to tell if this is the case or not. His first comment to Mrs Catanach is to speculate, "I thocht ye was luikin' whaur ye cam frae" (8), but this obsession with origins is just one of the ways in which the laird's difference from the other characters in terms of mental and physical ability is established. The novel's main plotline, furthermore, in its concern with Malcolm's progeniture, comes to reflect the mad laird's consistent preoccupation 
with his own origins, evident in his persistent catch-phrase, "I dinna ken whaur I cam frae!" This outcry maintains a strong thread throughout the novel, and makes up the central premise of the laird's supposed lunacy. On other topics he comes across as sane enough, although hampered by a speech impediment. In fact, the above sentence so frequently uttered by the laird is

the only one he invariably spoke with definite clearness. In every other attempt at speech he was liable to be assailed by an often recurring impediment, during the continuance of which he could compass but a word here and there, often betaking himself, in the agony of suppressed utterance, to the most extravagant gestures, with which he would sometimes succeed in so supplementing his words as to render his meaning intelligible. (36)

His inability to verbally communicate in general terms leads to the idea that he is suffering from a form of idiocy. His mind is declared by sympathetic characters as “though cawpable o' a hantle mair nor a body wad think 'at didna ken him [...], is certainly weyk - though maybe the weykness lies mair i' the tongue than i' the brain o' 'im efter a' -" (222). Later it is depicted in terms of his suffering, "in his puir feeble min"" (223), a lack of understanding which is a state to be pitied. But this, in turn exacerbated by his physical appearance, lends itself to the perception of him as a lunatic: "Some said he was a fool; others a madman; some both; none, however, said he was a rogue" (9). While a strong distinction was maintained between idiocy and lunacy at this time in the nineteenth century, the two labels become conflated in the character of the laird. ${ }^{59}$

\section{Attitudes to madness}

Despite the understanding shown by a number of characters close to the laird, several responses to his appearance and behaviour by other more secondary characters show not sympathy but horror and fear. In a conversation between two fishermen, for example, one tells the other:

he's a fearsome sicht whan he's ta'en that gait [...] I met him ance i' the gloamin', jist ower by the toon, wi' his een

\footnotetext{
${ }^{59}$ Henry John Stephen in New Commentaries on the Laws of England (1868; (ed. 6) II. ii. ii. v. 63) discusses the insane, "in which class are to be included idiots who have had no understanding from their birth, as well as lunatics who have lost the use of their reason."
} 
glowerin' like uily lamps, an' the slaver rinnin' doon his lang baird. I jist laup as gien I had seen the muckle Sawtan himsel'." (10)

The reader's interpretation of the laird's condition and of disability as it is functioning more generally in the novel is to a great extent informed by such general reactions to and treatments of his character. For example, reactions include fear and superstition, as revealed above, but also contemptuous pity, anger and embarrassment. Mrs Catanach, for example, views him as something to be manipulated and taken advantage of. She conspires with Mrs Stewart, the laird's mother, to kidnap him and keep him locked up in a lunatic asylum, so that Malcolm can be pronounced the rightful heir of Gersefell.

The lunatic asylum thus functions in the novel as a threat of confinement, an attempt to remove the laird from general society. As we shall see, the laird in his madness is frequently likened by the narrator to wild animals and other creatures threatened by predation. The desire of his mother to incarcerate him in "the asylum at Aberdeen, an' no lattin' him scoor the queentry this gait" (88) is regarded by Malcolm and other sympathetic characters as "sheer cruelty, for the cratur likes naething sae weel as runnin' aboot, an' does no' mainner o' hurt." The conflict represented by the lunatic asylum comes down to one between freedom and constraint. Characters sympathetic to the laird's plight (such as Malcolm and Miss Horn), advocate a freedom from constraint, while the villains of the text (Mrs Stewart and Mrs Catanach) stand to take away that freedom with the threat of confinement. Madness as it is seen in the character of the laird is presented in a positive light by right of its opposition to cruel treatment.

The reactions of the marquis' daughter, Florimel, to the character of the laird provide a useful measure of the function of madness in the novel. The relationship between Florimel and Malcolm is characterised as similar to other such pairings in MacDonald's novels. ${ }^{60}$ Florimel is both arrogant and ignorant, a shallow character whose spiritual development is monitored as the novel progresses. It is through her development of respect for Malcolm that she achieves this spiritual growth, and one way by which this is measured is her attitude toward the mad laird. She first comes across him in the company of Malcolm, when the two are caught on the beach during

\footnotetext{
${ }^{60}$ They can be compared to Clara and Wilfrid, for example, in Wilfrid Cumbermede or Arctura and Donal in Donal Grant.
} 
a thunderstorm. The atmospherics accompanying the encounter emphasise the experience of fear felt by the girl:

A roar of thunder followed, and even while it yet bellowed, a white face flitted athwart the grating, and a voice of agony shrieked aloud:

"I dinna ken whaur it comes frae!"

Florimel grasped Malcolm's arm: the face had passed close to hers - only the grating between, and the cry cut through the thunder like a knife.

Instinctively, almost unconsciously, he threw his arm around her, to shield her from her own terror. (88)

Florimel's perception of the laird is strongly influenced by the natural elements of the storm raging around them. The "flitt[ing]" of his "white face" suggests the flash of lightning, while the "shriek" of his agony reflects the movement aurally, as it "cut[s] through the thunder like a knife." Her terror is similarly tied up with her fear of the storm, further reinforcing the impact of the laird's appearance as akin to a force of nature.

Later, Florimel's fearful reaction to the laird is mimicked by the laird's own. As Mrs Catanach is standing contemplating Florimel resting on the sand, the laird too comes into view:

Lady Florimel started, half rose, and seeing the dwarf so near, and on the other side of her a repulsive-looking old woman staring at her, sprung to her feet and fled. The same instant the mad laird, catching sight of Mrs Catanach, gave a cry of misery, thrust his fingers in his ears, darted down the other side of the dune and sped along the shore. Mrs Catanach shook with laughter. (102)

The episode suggests a relationship of sympathy between the two characters, a bond forged through mutual fear of a third party, Mrs Catanach, and that enemy's inclusion of both of them in her laughter.

The above reference to the laird as "the dwarf," made by the narrator but focalised through the character of Florimel, highlights the importance of physical appearance to his treatment at the hands of others. As mentioned, the relationship between physical appearance and madness in the nineteenth century was primarily focused through the "pseudo-science" of physiognomy, which postulated the "consonance of body and character" (Wiesenthal 4). While it came to be defined as 
primarily involving the facial features, it did at times include the form of the body as a whole. As the eminent nineteenth-century psychiatrist John Conolly noted in the $1850 \mathrm{~s}$, "a mad man's whole exterior becomes indicative of his interior commotion or of his disordered state of mind" (210). In the case of the mad laird, it is his physical body as a whole which correlates with his apparently disordered mind. Along with his distinctively short stature, the laird himself in his attitude and movements has "a dim notion that all his trouble had to do with his hump" (56). It is his hump, furthermore, that is described by the narrator as the "sad symbol of his weight of care" (35), while in terms of his mental faculties, it is his disinclination to speak that makes it "impossible to tell how much he understood" (36). Malcolm describes the laird's suffering as involving a "tortured mind" and "sickly frame" (127). He is also subject to "fits" (129), which are usually instigated by references to his mother.

The laird's preoccupation with his origins derives from a distrust and even horror of his mother. We know that any reference to her results in one of his fits, when he puts his hands over his ears as if to block out any reference to her, and runs away to a place of safety. We learn that this stems back to his mother's ill treatment of him because of his deformity, but also because of her guilt about his birth. The rumour is that Mrs Stewart had an adulterous affair with the late marquis, which resulted in the birth of the poor hunchback. As Miss Horn explains: "he's aiblins the child o' $\sin [\ldots]$ an' beirs the marks o' 't, ye see'; sae to her [Mrs Stewart] he's jist her sin rinnin' aboot the warl incarnate; an' that canna be pleasant to luik upo"” (152). It is so unpleasant, in fact, that she plots to have her son shut up inside the Aberdeen lunatic asylum. ${ }^{61}$

The idea of the laird's deformity as caused by his mother's adulterous $\sin$ is reminiscent of long-held popular beliefs regarding the influence of the mother's imagination on her unborn child. We are told that the laird was born "humpit" (151), inferring some sort of birth deformity such as infantile scoliosis or other spinal defect. Mrs Stewart's reaction to her son's physical appearance, however, and the community's superstitions, posit her adulterous thoughts, and perhaps the sin of

\footnotetext{
${ }^{61}$ Aberdeen lunatic asylum was an institution actually existing in MacDonald's time, and which the author must have been aware of, growing up nearby, as he did, in Huntly, and attending university just round the corner.
} 
adultery itself, as the cause of the monstrous birth. ${ }^{62}$ Miss Horn puts to Malcolm the idea that

maybe she [Mrs Stewart] wadna care gien 't warna for the oogliness o' im [the laird]. Sae be he was a bonny sin, I'm thinkin' she wad bide him weel eneuch. But seein' he's neither i' the image o' her 'at bore 'im nor him 'at got 'im, but beirs on 's back, for ever in her sicht, the sin 'at was the getting' o' ' $m$, he's a' hump to her, an' her hert's aye howkin a grave for 'im to lay 'im oot o' sicht intill: she bore 'im, an' she wad beery 'im. (152)

The specific positioning of the laird as a visual reminder to his mother, "for ever in her sicht," makes of him the embodiment or symbol of her sin. His physical resemblance neither to her nor to his father ("him 'at got 'im") has a context in contemporary science. By the nineteenth century, scientific discoveries in the areas of embryology and heredity meant that belief in the power of the mother's imagination to affect her unborn foetus was dwindling. At the same time, however, as Marie Hélène Huet has shown, it became a central theme of Romantic aesthetics (7), and the monster appears "as the public display of all secret, and at times illegitimate yearnings" (17).

According to Huet, the particular scandal of the monstrous birth was the erasure of the father's image $(8,33)$, providing a very public reminder of the unreliability of paternity. This is intensified in Malcolm by the fact that the laird's official father, Mrs Stewart's husband, is erased not only in this figural sense of his genes being replaced by those of another man, but also through his physical death. In fact, it is suggested in the novel that Mrs Stewart herself had a hand in her husband's death: "the man who killed her husband in a duel was a friend of hers" (152). Not only this, but the laird's actual (biological) father, the late marquis, is also dead, thus sealing the symbolic relationship between the two. Father and husband are thus erased in terms both metaphorical and literal. The similarity in the facial features of the laird and Malcolm in terms of refinement and nobility, in spite of the former's deformity, is another early hint as to their closer relationship, and further reinforces the importance of resemblance to issues of paternity.

\footnotetext{
${ }^{62}$ In Marie Hélène Huet's Monstrous Imagination, for example, she notes that other causes attributed to the "monstrous birth" include "sex with the devil or animals" (3).
} 
While in conversation with Mrs Catanach, and plotting to lock the laird up, Mrs Stewart mentions the rumour that her son "was no worse than poor treatment had made him - for you know his father could not bear the sight of him" (196). The suggestion of maltreatment on the part of Mrs Stewart towards her son is also suggested by her likeness to Mrs Catanach: the similarity of his mother's portrayal to the more obvious villain of the text does much to position the laird in a sympathetic light. The two women are described in similarly emotive terms as predatory animals, specifically cats. For example, Miss Horn refers to Mrs Catanach as "a catwuman" (50), while Mrs Stewart is described by the narrator as a lady with "a motion that might have suggested the lithe grace of a leopard" (218). ${ }^{63}$ Near the end of the novel, Mrs Stewart's claim on Malcolm as her son is likened to "the clutches of a vampire demon" (412). The depictions of these two characters in predatory terms highlight the nature of their relationship with the laird as one of hunters and hunted. The laird's fear of his mother leads to his depiction in terms of wild or hunted animals. In his flight from her at numerous points in the novel, the laird is compared to "a hunted creature" (9), a "fretted horse" (128), a "scared animal" (128), a "wild creature" (328), and "a hare just escaped from the hounds" (358). When the laird first speaks with Mrs Catanach in the opening chapters of the novel, furthermore, the two characters are placed in a relationship of power imbalance: the laird's "pathetic, dog-like expression" (7) and "childlike entreaty in his voice," together with his "dwarfish height" and necessary upward gaze reinforce these childlike associations. The laird as such a figure of innocence at the mercy of others is then reinforced later in the novel when, having rescued him from his mother's henchmen, Malcolm gathers him up in his arms, "like a child," while "as if she had been his mother, [Miss Horn] washed his face and hands, and dried them tenderly, the laird submitting like a child" (147).

\section{The mad laird and King Lear}

The characterisation of madness in the novel, and in particular its position within the myriad of family relationships established in such a portrayal resonates with Shakespeare's King Lear. Coppélia Kahn reads Lear's madness as “essentially his rage at being deprived of the maternal presence" (41). According to Kahn, Lear's

\footnotetext{
${ }^{63}$ The idea of the predatory cat as a symbol for an evil mother figure is repeated in at least two of MacDonald's later novels, The Flight of the Shadow (1891) and Lilith (1895)
} 
children become "daughter-mother" figures (40), as the king regresses to what is essentially an infantile disposition. Kahn inserts the image of the rejecting mother in Cordelia's refusal, in the first scene of the play, to love her father more than a husband. The situation is thus one in which Lear's madness is essentially a "childlike rage" (41) from being deprived of maternal care. After her rejection, Lear then banishes Cordelia from his presence, disclaiming,

$[\ldots]$ all my paternal care, Propinquity and property of blood, And as a stranger to my heart and me Hold thee from this forever. (1.1.107-110)

Unlike Lear, who at the start of the play is the one in the position of power, the laird is at the mercy of his mother throughout the novel. He is also unable to give voice to his hatred for his mother, but his behaviour reflects Lear's sentiments: "He never went near his own house, for $[\ldots]$ he had such a dislike to his mother that he could not bear to hear the name of mother, or even the slightest allusion to the relationship" (9).

Mrs Stewart makes the claim that Malcolm is her natural son in an attempt to wrest control over the estate of Kirkbyres from the laird, because, according to her, "her son's trustees, partly to indulge their own aversion to her, taking upon them a larger discretionary power than rightly belonged to them, kept her too straitened, which no doubt in the recoil had its share in poor Stephen's misery" (401). Lear's plight too comes to be based in a struggle over land and power. After he has divided his kingdom between his remaining two daughters, the parallels with MacDonald's story become even more enhanced. Once Gonerill and Regan have taken over control of the kingdom from their father, they refuse to care for him as they had promised to do. Lear's anger redefines their relationship. He labels Gonerill a "[d] egenerate bastard" (1.4.209), and wishes on her "derogate body" (235) that "[i]f she must teem,/Create her child of spleen, that it may live/And be a thwart disnatured torment to her" (236-238). This attitude reflects once again the relationship between the laird and his mother, who 'wad sae misguide the son o' her ain body, an' for naething but that, as she had broucht him furth, sic he was" (294).

In a similar fashion, it is his daughters' treatment of Lear that leads to the king's leaving them to wander the heath, accompanied, significantly, only by a fool. 
When Kent is in search of him, his enquiries are met with the response that the king is "[c]ontending with the fretful elements" (3.1.15). The king himself equates the weather with his own madness, pointing out to Kent in the midst of such a tempest:

Thou think'st 'tis much that this contentious storm Invades us to the skin: so 'tis to thee. But where the greater malady is fixed, The lesser is scarce felt. Thou'dst shun a bear, But if thy flight lay toward the roaring sea, Thou'dst meet the bear i'th'mouth. When the mind's free, The body's delicate. This tempest in my mind Doth from my senses take all feeling else, Save what beats there: filial ingratitude. (3.4.6-14)

The greater malady of his daughters' treatment of him makes the violence of the weather insignificant. The laird is also frequently described in a setting of wild weather, as if the weather emulates in some way his state of mind. It is during such a storm, for example, that Florimel first encounters him: "even while [the thunder] yet bellowed, a white face flitted athwart the grating, and a voice of agony shrieked aloud" (88). The same imagery connecting the external world with the internal is used to describe Malcolm himself, as the two characters merge towards the end of the novel. Upon hearing the rumour that he too is a son of Mrs Stewart, Malcolm walks along the shore: "in his mind brooded a single haunting thought that already had almost filled his horizon, threatening by exclusion to become madness" (314). The haunting thought becomes, through MacDonald's use of language, a dark cloud on the horizon of his mind.

In "The Absent Mother," Kahn argues that when Lear reappears in the final lines of the penultimate act of the play, "he is as helpless as a child" (47). Cordelia refers to him in such terms, praying

O you kind gods, Cure this great breach in his abused nature; Th'untuned and jarring senses $\mathrm{O}$ wind up Of this child-changèd father!

Lear's reliance on Cordelia in these final scenes is a curious conglomeration on the relationship between parent and child. Similarly, with regard to MacDonald's novel, the comment is often made regarding the laird's madness, that "a bairn could lead 
him," or handle him, as shown by his special relationship with the ten-year-old Phemy Mair. Their relative ages are reversed in scenes where the child calms and comforts him. Phemy is "familiar with his appearance, his ways, and his speech; and she was a favourite with him" (12). The laird speaks to her, "in strange yet to her comprehensible utterance" (14), and by the end of the novel, "as he became yet more peaceful in her company, his thoughts flowed more freely, and his utterance grew less embarrassed; until at length, in talking with her, his speech was rarely broken with even a slight impediment" (353). With gentle treatment, therefore, that aspect of the laird's disability involving thought process and its translation into speech is minimised.

\section{Transcending madness}

While the physical deformity of a hunched back and "dwarfish height" (as we now know) are most likely the products of nature not nurture, it is thus suggested in the novel that the mental and behavioural aspects of the laird's disability are perhaps at least in part the result of neglect, or worse, abuse. What is emerging is a split in significance between the laird's physical and mental disabilities. While his mental state differentiates him from the other characters in the novel, reinforcing the notion of individualism in the novel and highlighting the gulf that exists between people, the physical aspects of the laird's deformity can be seen in more general terms. While Robb argues that the character of the laird stands for the "falling-off" of humanity from the human ideal, the portrayal of the laird's physical deformity can be seen to more specifically correspond to the notion of the physical body as corrupt, a superfluous shell to be discarded after death, once the soul has transcended into heaven. In this way, the laird becomes not only a symbol of mankind in his relationship to physical form, but even more of a Christ figure. The suffering he experiences as a result of both physical and mental disability suggests Christ's role as sacrificial victim.

While his physical limitations can be read in such a positive light, the laird's supposed insanity is also not necessarily a negative portrayal. In his affinity with children and animals his character conveys a sense of natural innocence, but the nature of his madness is also given a more definite value in the idea of the sacred. The laird's physical deformity functions primarily as a means of exploring the 
significance of transcendence. Malcolm, in thinking of the laird and his suffering, questions the benevolence and wisdom of a God who would "permit a creature to be born so distorted and helpless as the laird, and then permit him to be so abused in consequence of his helplessness" (157). He eventually manages to reconcile the condition of the laird with the idea of a benevolent God, by reference to the afterlife. Mr Graham, the schoolteacher, in his naturally didactic role, is the means of introducing many such ideas in the novel (several of which are recognisable themes in other of MacDonald's works) through his teaching practice. For example, in discussing the laird's condition with Malcolm, he states, "It's my opinion that you are, as it were, asleep now, and that the moment you die, you will feel as if you had just woke up, and for the first time in your life. For one thing you will see far better than any of us do now" (183). ${ }^{64}$ Graham goes on to describe the physical body as "but a sort of shell that we cast off when we die" (184), and Malcolm too describes the laird as "a misshapen heap of man, a tumulus in which lay buried a live and lovely soul":

The one pillar of its chapter house had given way, and the downrushing ruin had so crushed and distorted it, that thenceforth until some resurrection should arrive, disorder and misshape must appear to it the law of the universe, and loveliness but the passing dream of a brain glad to deceive its own misery, and so to fancy it had received from above what it had itself generated from its own poverty below. To the mind's eye of Malcolm, the little hump on the sand was heaved to the stars higher than ever Roman tomb or Egyptian pyramid, in silent appeal to the sweet heavens, a dumb prayer for pity, a visible groan for the resurrection of the body. (129)

Physical deformity becomes not only more acceptable or palatable when viewed as a mere temporary burden to be shed at death (the comparison of the laird's prostrate body to a tumulus, a Roman tomb and an Egyptian pyramid), but more significantly as a source of intensified sacredness through the idea of sacrifice. For example, when Malcolm comes across the laird in the above position, lying prone on the ground after mention of his mother, he realises that he is praying, and "[m]aniac or

\footnotetext{
${ }^{64}$ The emphasis on sight here, as being perfected after death, while not quite so pertinent in the case of the laird's disability, is immediately suggestive of the case of Malcolm's blind grandfather, whose condition in many ways informs that of the laird. This relationship will be explored in more depth at a later point in the chapter.
} 
not - the mood of the man was supremely sane, and altogether too sacred to disturb" (129). The laird's disability, both physical and mental, places him in a higher position spiritually than even Malcolm himself. His character has shifted from one to be pitied to one of awe. As the laird lies dying, following a final altercation with his cruel mother, Malcolm likens his friend's suffering to "wandering in the thorny thickets and slimy marshes which [...] beset the gates of life" (404).

The laird's state of madness as a mark of spiritual superiority in the novel is emphasised through the similarities he shares with Malcolm's grandfather, the blind piper. Duncan MacPhail's character runs parallel to that of the laird in a number of ways. Firstly, he too is initially described as "a strange figure to look upon" (28), but this is due to his unusual clothing: traditional highland dress. He is also, however, primarily characterised by an innate physical disability, in this case blindness:

It came neither of old age nor disease - he had been born blind. His eyes, although large and wide, looked like those of a sleepwalker - open with shut sense; the shine in them was all reflected light - glitter, no glow; and their colour was so pale that they suggested some horrible sight as having driven from them hue and vision together. (23)

Like the laird's stature and hump, Duncan's eyes are a visible symbol of his difference within society. And like the connection made between the laird's deformities and the sin of his mother, Duncan's sightless eyes are symbolically attributed to "some horrible sight."

It is not only in terms of his physical disability that Duncan MacPhail is a character comparable to the laird. He too is consistently referred to by other characters in the novel in terms relating to madness. Soon after Malcolm starts working for the marquis, his grandfather is invited to attend a dinner and play his bagpipes. Dressed in traditional garb, the old man becomes an object of mockery for the guests, "a picture ludicrous to a vulgar nature, but gently pitiful to the lover of his kind" (106). After having a cruel joke played on him, where one of the guests stabs the bag of his instrument with a knife so that he can no longer play, Duncan reacts strongly: "he was running wildly about the room, brandishing his weapon, knocking 
over chairs, and sweeping bottles and dishes from the table" $(110) .{ }^{65}$ It is the reaction of the guests, however, that is particularly telling, one commenting, "What a horrible savage... He ought to be shut up in a madhouse" (111). Florimel, furthermore, is "sorry for the old man" but still determines that he "must be mad" (118); and the marquis' only desire to apologise for the incident comes from the thought that "[i]t would be quite horrible never to be quits with the old lunatic" (118).

However, it is Duncan's blindness rather than his "mad" behaviour that, in a similar fashion to portrayal of the laird, connects him inadvertently to a higher spiritual realm. This becomes apparent early on in the novel, when he and Malcolm are saying their prayers. ${ }^{66}$ As he prays, "the sightless eye-balls of the singer had been turned up towards the rafters of the cottage - a sign surely that the germ of light, 'the sunny seed,' as Henry Vaughan calls it, must be in him, else why should he lift his eyes when he thought upward?" (24-5 original italics). This "sunny seed" to which MacDonald and Vaughan refer is that part of the individual that looks to God, the "magnetism" of which, "works all night / And dreams of Paradise and light" (Vaughan 5-6). The contrast established in Vaughan's poem between darkness and light, with its association of the day with heaven, resonates strongly with MacDonald's character in his literal blindness. One's time on earth, furthermore, as equated with a dark night from which one will eventually awaken, is also familiar to us from both Novalis and von Schubert's philosophies. MacDonald, too, as he does with the mad laird, is using the physical shortcomings of the blind piper to emphasise the limitations of human life in light of what is to come. While the laird, during one of his fits, is credited with a mood, "altogether too sacred to disturb" (129), and his distorted body compared to a chapter house, Duncan's blindness is similarly credited with giving him access to a spiritual or higher realm: "[h] is eyes, or indeed perhaps rather his whole face, appeared to possess an ethereal

\footnotetext{
${ }^{65}$ His extreme reaction is one set off not only by the damage done to his beloved pipes, but also the mention made by someone to the name of Campbell: "At the word Campbell, the piper shook off his grandson, and sprang once more to his feet, his head thrown back, and every inch of his body trembling with rage" (110). Duncan is incensed at the name because of a clan grudge, and it acts as a trigger in much the same way mention of the laird's mother does for that character. A common feature shared by the two characters is something akin to a monomania. Significantly, both mental obsessions have a basis in origins, and as such with personal identity.

${ }^{66}$ The prayer in question, psalm 103, begins, "Bless the Lord, O my soul: and all that is within me, [bless] his holy name" (KJV). The choice of psalm here, specifically the phrase, "all that is within me," aligns with the focus of my wider argument.
} 
sense of touch, for without the slightest contact in the ordinary sense of the word, he was aware of the neighbourhood of material objects, as if through the pulsations of some medium to others imperceptible" (27, italics mine). Such a description recalls von Schubert's idea of magnetism, whereby those under the influence of divine love experience episodes akin to somnambulism. Duncan's "awareness" of his surroundings despite his lack of sight is attributed to a sense of the "ethereal."

\section{Madness and Identity: "A common humanity"}

Identity and its relationship to the mind of the individual is a strong presence in this novel. The narrator introduces the mind/brain duality in the makeup of identity through the character of Malcolm when the latter, upon being woken in the middle of the night, asks, "is it that the brain wakes before the mind, and like a servant unexpectedly summoned, does not know what to do with its master from home? or is it that the master wakes first, and the servant is too sleepy to answer his call" (264). The mind's superiority over the brain implies also its reliance on the brain for comprehension and clarity. The relationship between the physical and the mental is further developed in the case of Malcolm, and is once again a source of comparison between his character and that of the laird. For example, after having injured his foot in the course of rescuing Florimel from a fall on the cliffs, Malcolm has "for the first time [...] a notion of how far bodily condition can reach in the oppression and over-clouding of the spiritual atmosphere" (271). He asks himself, "Gien I be lie this [..] what maun the weather be like aneth yon hump o' the laird's!" This comment attributes some or perhaps all of the laird's mental problems to the difficulty of having to deal with his physical limitations, which once again brings in the impact of his mother's cruelty towards him in childhood. ${ }^{67}$

This insistence of focus on what makes up the individual character lends itself to an exploration of the relationships between individuals, how individuals bridge "the abyss" (81) between souls. This is perhaps most apparent in the developing relationship between Florimel and Malcolm. When they first meet, for example, it is their social difference which is immediately highlighted. Florimel sees

\footnotetext{
${ }^{67}$ Malcolm's comment also functions as a reminder of MacDonald's own battles with physical health both as a child and an adult. His frequent bouts of tuberculosis left him several times confined to his bed, and the frustration he felt at such restriction can be seen in a number of his novels, including not only Malcolm, but Adela Cathcart, and At the Back of the North Wind.
} 
Malcolm as "human indeed, but separated from her by a gulf more impassable far than that which divided her from the thrones, principalities, and powers of the upper regions" (18). Both characters sense this difference, but definite ambiguity and contrast is evoked in the response of each to their interaction, providing a means of crossing this "impassable gulf":

Either her sense of his inferiority was such that she regarded his presence no more than that of a dog, or, possibly, she was tempted to put his behaviour to the test. He, on his part, stood quietly regarding the operation, either that, with the instinct of an inborn refinement, he was aware he ought not to manifest more shamefacedness than the lady herself, or that he was hardly more accustomed to the sight of gleaming fish than the bare feet of maidens. (18)

The ambiguity attributed to the action of each through the structure of "either/or" suggests instead of difference between the two characters, a common humanity: both cases are allowed to stand in their uncertainty. The difference between them in terms of class becomes a symbol for the more literal but also metaphysical ways in which one individual can come to "know" another.

This idea of a common humanity which surpasses differences as broad as social concern and mental disability comes through strongly in a particular incident which takes place at the House of Lossie. Malcolm comes across an arbour in the garden, into which he enters in order to shelter from a sudden shower of rain. As he does so, however, an extraordinary apparition appears:

[U]p rose a pale, hollow-cheeked, emaciated man, with eyes that stared glassily, [who] made a long skeleton-like stride towards him, and held out a huge bony hand, rather, as it seemed with the intent of clutching than of greeting him. (273)

As it turns out, however, the creature is merely a dummy, "the foolish whim of a past generation" (272), built into the arbour. The incident is a curious one, especially when viewed in light of the novel's preoccupation with identity and self. The automaton is of course a human form without any sense of self or identity, primarily because it is without an inner life. The movement of reaching out one's hand in order to "clutch" or "greet" suggests the above metaphorical idea of "bridging the gulf" between individuals, but Malcolm's "horror" at the very idea of touching the 
creature highlights the impossibility of this: "it was the oonnaiteral luik o' the thing - no human, an' yet sae dooms like it. [...] An' even noo 'at I unnerstan' what it is, I kenna what wad gar me luik the boody (bogie) i' the face again" (273). The dummy is conceived of as significantly different from Malcolm, "no human," unlike the laird with whom, despite his deformity and difference, Malcolm is able to establish a connection (as can be seen by the above parallels between the two characters). ${ }^{68}$

The incident with the automaton highlights the situation of the laird, and his trouble relating to and communicating with other people. The focus placed on issues of communication and understanding, and the relationship of such concepts to selfknowledge is similarly emphasised in the case of the blind piper. While the old man's speech and behaviour is viewed as mad by the members of the marquis' family and by his guests, he is definitely not seen as such by the people of the town who know him. Madness thus becomes in part a term the designation of which is based on the extent to which an individual is understood by others. The marquis and his guests do not know Duncan and as such interpret his speech and behaviour as mad. For the people living in the town, on the other hand, Duncan is a functioning member of the community: he is the town piper and maintainer of lamps, and thus has a specific role or niche in his society. The laird does not have any such role, and so his relationship to the townsfolk is one similar to that between Duncan and the marquis: they are unable to relate to him. This idea is clarified not only by the burgeoning understanding between him and Malcolm (in the possibility of a shared parentage), but also by his relationship with Phemy, the girl with whom he has established a friendship. With Phemy the laird is able to make himself understood, and her treatment of him is thus distinct from that of others. MacDonald's emphasis on the importance of a mutual understanding between individuals is also made clear in a conversation between Malcolm and Mrs Courthope, the housekeeper at Lossie House. Malcolm, in considering his grandfather's condition, determines that "a blin' man, like my gran'father, canna ken himsel' richt, seein' he canna ken ither fowk richt. It's by kennin' ither fowk 'at ye come to ken yersel, mem - isna't noo?” (47).

\footnotetext{
${ }^{68}$ This incident is remarkably similar to one in Donal Grant, the subject of the next chapter, where the drug-crazed earl is depicted in similar terms as a creature to be feared, "a present but deserted body" (Donal Grant 137). The description here of the automaton is also reminiscent of the creature in Mary Shelley's Frankenstein, and thus looks forward to the mechanical state of lord Morven, with whom such a comparison will also be made in the following chapter.
} 
Mrs Courthope counters his argument, however, maintaining that "[b]lindness surely doesn't prevent a man from knowing other people. He hears them, and he feels them, and indeed has generally more kindness from them because of his afflictions."

This focus on the individual and that individual's relationship to another is extended further in the idea of God, and the role a supposedly benevolent, allpowerful being has in the makeup of that individual, especially one seen as disabled or deformed in some way. Von Schubert's notion of the human mind's connection to the divine through a language other than that of human speech (as discussed in the introduction to this thesis) is thus brought to the fore. Characters subjected to physical limitation in this novel are granted other means to communicate.

MacDonald's implication of a Manichean universe (the existence of both a good and an evil force in the universe), which is primarily developed through the character of the schoolmaster, Mr Graham, is furthermore resolved by the use of disability to highlight the temporary nature of life on earth: the view that the physical body is but a shell to be cast off when we die and the soul transcends into heaven. This idea of human disability as a symbol for the corrupt nature of human life is compounded by issues of progeniture and biological inheritance, issues which were coming into prominence in the nineteenth century with developments in fields such as embryology. While perhaps not directly exploring issues of the mind, the focus on the individual that comes through in the use of disability in this novel continues MacDonald's preoccupation with human identity and what it means to be human the exploration of the mind being but one facet of this diverse subject. The novel connects quite closely with Wilfrid Cumbermede through MacDonald's emphasis on issues of inheritance, and also through the more holistic view of identity, perhaps more so than those novels which focus on a more specified concept of the mind. Or, rather, each text is concerned with a holistic notion of human identity, but this is explored with a different focus: the construction of the mind (Phantastes, Donal Grant), the relationship between the mind and the body (Donal Grant, Adela Cathcart), and the relationship between the physical body and the immortal soul (Malcolm). 


\section{Chapter Five: \\ "Home-born phantoms": the drugged mind in \\ Donal Grant}

\section{Introduction: a wicked art}

Donal Grant, first published in 1883, is MacDonald's longest novel. It follows on from the much more popular Sir Gibbie (1879), and is the novel about which MacDonald had once discussed collaboration with Mark Twain. MacDonald's intention was to protect each author from the loss of income affecting both from transatlantic copyright laws. Twain demurred, however, on the grounds of his own work pressures, as well as feeling (as Lindskoog puts it), "doubtfulness about the success of collaborative efforts" (110). As a novel, Donal Grant has been generally dismissed by modern critics, who have described it as merely repeating several "worn-out themes" from the author's earlier books, without any sense of reworking or extension. ${ }^{69}$ William Raeper describes it (along with others) as "pure romance" (George MacDonald, 209), despite allowing it to be an example of "development" in MacDonald's writing. Edmund Cusick bestows some credit on the author's use of dreams, describing them as "convincingly reproduced (and seriously considered) in a way that is unique in Victorian fiction" (57). ${ }^{70}$ This is his only reference to Donal Grant, however, and the novel is even omitted from the article's bibliographical list. Rolland Hein, in The Harmony Within: the Spiritual Vision of George MacDonald (1982), makes mention of the novel only in terms of its status as sequel to the obviously preferred "novel of great charm" (127), Sir Gibbie. Earlier reviewers, too, as Jennifer Koopman notes, found little of value in the novel, drawing attention merely to the repetitive sermonising of both the narrator and the eponymous hero. Koopman herself, however, in her unpublished thesis Redeeming Romanticism: George MacDonald, Percy Shelley, and Literary History (2006), argues for a more

\footnotetext{
${ }^{69}$ See, for example, Robert Lee Wolff's The Golden Key $(1961,294)$.

${ }^{70} \mathrm{~F}$. Hal Broome also mentions the novel in his discussion of "The Scientific Basis of George MacDonald's Dream Frame" (in William Raeper (ed), The Gold Thread: Essays on George MacDonald, 1990), but the reference is general and the novel is not honoured with any close attention.
} 
"sustained critical assessment" (137) of the novel, describing it as "one of the most conceptually ambitious" (138) of MacDonald's works. Koopman reads the story with a focus on literary history, noting frequent references to the Romantic poet, Shelley. She reads the repetitive elements so prevalent in the novel as "deliberate steps on the visionary path to apocalypse and transcendence" (203).

While this stands as both a valuable and an insightful reading of Donal Grant, and while I agree wholeheartedly with Koopman's claim for the great ambition of the text, I would like to take the discussion of the novel in an entirely new direction. Koopman argues (particularly in her chapter on 'The Cruel Painter") that MacDonald's attitude to science is negligible. She highlights the author's "mistrust" (111) of the discipline, illustrating the notion with the example of Teufelsburst and his "wicked art” (111). The painter's behaviour (the drugging of his apprentice in order to more clearly observe his pain in love) is taken even further in Donal Grant, however, where the previous story's depiction of experimentation with drugs, and the consequences of this, is magnified in the character of the demonic lord Morven. Such insistent and recurring portrayal of experimentation, and the depth of detail involved in describing the effects of such substances as Morven dallies with, point rather to MacDonald's obvious scientific interest in the subject. The similarities between the two characters, the earlier and the latter, along with the explicit development of thought inherent in the description, shows MacDonald's fascination with the physical workings of the brain, as well as the less tangible workings of the mind. While in Adela Cathcart (the framing narrative and the stories contained within) a medical concern for the mental health of its young protagonist is central, in this later novel there is an equal concern for the pathology of drug addiction. MacDonald insistently draws attention to the working of the brain as physically prompted. His conception of mental states is conveyed by his use of architectural metaphors, and the motif of "haunting" - narrative strategies also seen in Phantastes' landscape of the mind and Malcolm's portrayal of madness. Indeed, the novel bears witness to MacDonald's familiarity with drug addiction as described by his professional (and literary) contemporaries. 


\section{Opium use in the nineteenth century: a brief overview}

The effects of opium on the human mind have been known for about six thousand years. It had an early and significant place in Greek, Roman and Arabic medicine. Opiates are commonly included in the category of narcotics, drugs which induce drowsiness, stupor or insensibility. One opiate, morphine, was named after Morpheus, the god of sleep. It has a euphoric effect, and, according to Berridge and Edwards, "the patient is emotionally distanced from what is happening, and floats as it were on the surface of his experience" (xxi).

Official regulations concerning the use of 'dangerous drugs' such as opium were not yet in place at the time MacDonald was writing. In fact, it was not until at least ten years after the author's death in 1905 that the first laws were passed, which saw narcotics become a matter of social policy: the 1916 Defence of the Realm Act regulation 40B dealing with cocaine and opium and the 1920 Dangerous Drugs Act (Berridge and Edwards, xxi). However, it was during the years of MacDonald's life, itself spanning almost the entire nineteenth century, that the groundwork for such controls was laid, and the use of drugs began to be examined under an official lens. While a number of medical tracts in the eighteenth century addressed the subject of opiate addiction, they were lacking in any sense of moral condemnation or hysteria (Berridge and Edwards, xxiv). Alongside the problems of addiction, furthermore, these tracts tended to highlight the positive aspects of opium use, which included the interest and wonder it inspired as deriving from an Eastern way of life.

It was in the nineteenth century, then, that attitudes towards such drugs as opium changed. In the 1850 s, opium could be bought in any grocer's or druggist's shop; by the end of the century, the drug and its products and derivatives, as well as any opium-based patent medicines were only to be found in pharmacists' shops (Berridge and Edwards, xxvii). Over the same decades, regular users went from being accepted members of their communities to bearers of labels denoting sickness, disease or deviance. ${ }^{71}$ Berridge and Edwards point to the class system as the root cause, given that it was the addiction to the drug of the lower or working classes that was most likely to be seen as problematic (xxviii). The 1868 Pharmacy Act saw the "professionalization of the sale of patent medicines," placing drug use primarily in the control of the medical profession (Berridge and Edwards, xxix). Once the

\footnotetext{
${ }^{71}$ Note earlier passage where the earl's condition was described as a "disease" four times.
} 
working classes were seen as under official control by the Pharmacy Act in terms of their drug habits, doctors and other members of the medical profession began to focus on the question of hypodermic morphine.

Morphine was the first opium alkaloid to be produced, becoming known in Britain in the early 1820s, about the time of MacDonald's own birth. By the midnineteenth century, it was being used regularly as both an external and an endermic analgesic. While the intravenous method has a relatively long history (drugs, including opium, had been injected into both animals and man since at least the seventeenth century), it was not until this time that the hypodermic injection was developed. H. H. Kane, in his book The Hypodermic Injection of Morphia (1880), describes the discovery of the "subcutaneous method" of administering drugs by Dr Alexander Wood of Edinburgh in 1855 (Kane, 13). With this came a great enthusiasm on the part of the medical profession for hypodermic morphine, seen as a far more effective form of pain relief than ordinary opium. Medical journals up until the 1870s were filled with articles in praise of its effects on patients. But the less positive effects of long-term morphine addiction were soon to emerge.

\section{Eduard Levinstein's Die Morphiumsuct nach Eigenen Beobachtungen} (1877), translated into English as Morbid Craving for Morphia (1878), was the first comprehensive account of morphine addiction. The study was instrumental in defining the addiction (commonly known as "morphinism") as an actual condition or disease, likening it to dipsomania, or the delirium produced by excessive drinking (5). As a result of such prominent studies as Levinstein's, by the beginning of the 1880s case histories of morphine addicts had replaced those glowing reports of morphine use in the medical journals described earlier. Little mention was made, however, of the fact that the 'condition,' as it were, frequently had its origin in original legitimate prescription by doctors, and the eventual self-administration of the drug by patients. As Berridge and Edwards insist, decisions on treatment and medical intervention were, even in the middle of the century, often made by the patient rather than the doctor. We can see this in Donal Grant through the relationship between the morphine-addicted earl and his old doctor, "Dowster" (370), before the interference of the protagonist, Donal. Morven declares that he will only see his "old attendant" (370), whose previous treatment has fostered his addiction, but Donal refuses. He appoints a new doctor, whose willingness to enforce the strict withdrawal treatment is crucial to the story. Donal appoints Dr 
Avory because he recognises in him a new regime. MacDonald is clearly arguing for a change to the old system, whereby power of prescription and self-medication is withdrawn from powerful and/or wealthy patients. ${ }^{72}$ As we shall see, however, the campaign for such a change is secondary in the novel to the more pressing concern of spiritual health.

\section{"A present but deserted body": drugs and the strength of the spirit}

In Donal Grant moral and physical strength go hand in hand, and drug addiction provides one means of highlighting the connection between such values. The ailing lord Morven is morally destitute and this is reflected in his weakened physical state and in his dependence on drugs. He is initially and consistently described as an invalid, suffering from bouts of fatigue and debilitating headaches. These are attributed by the castle's housekeeper, in conversation with Donal, to the fact that he "was with the army in India, and the sun, they say, give him a stroke, and ever since he have headaches that bad!" (57). It is suggested that it was these headaches that led him to the use of opium and its derivatives, on which he soon became dependent. His niece Arctura's explanation for her uncle's drug-taking goes beyond mere pain relief, as she tells Donal "my uncle is in the habit of taking some horrible drug for the sake of its effect on his brain" (159). The book is interspersed with descriptions of the earl under the influence of such narcotics, wandering the castle in a daze and apparently unaware of what is happening around him. On Donal's first night there, for example, he awakens to investigate a noise and while exploring discovers the earl:

The apparition turned its head towards him; but in its look was no atom of recognition, no acknowledgement or even perception of his presence; the sound of his rising had had merely a half-mechanical influence upon its brain. [...] Was this man out of his mind, or only a sleepwalker? (136)

MacDonald describes the state as one of emptiness, as a lack of humanity. The earl's condition has made him a monster: "There is something more terrible in a presence that is not a presence than in a vision of the bodiless; that is, a present ghost

\footnotetext{
${ }^{72}$ It can be argued, however, that in this new scenario the doctor is still not in charge as his first job is to do exactly what Donal tells him.
} 
is not so terrible as an absent one, a present but deserted body" (137). ${ }^{73}$ What is emphasised here is the relationship between the body and the mind, or the spirit. A body without an inhabiting spirit is, for MacDonald "more terrible" than a spirit without a body (in other words, a ghost). The word "mechanical" is used frequently throughout the novel, usually in connection with the earl's drugged mind-state and its effects on Donal. For example, on his own night-time explorations of the castle, Donal's movements too are described as "mechanical" (135). When the earl goes on to give him wine that has been laced with opiates, Donal drinks it unknowingly but goes on to fill his glass "half-mechanically" (145). "Mechanical" seems to work in such situations in a derogative sense, the effects of narcotics contrasting with the otherwise "natural" state of Donal's mind.

What Donal at first mistakes for sleepwalking in the earl, he soon discovers to be instead a drugged state, one which the earl is keen to also inflict on others. No explanation is given as to why he attempts these experiments; one cannot help, however, but extend to the earl that motivation attributed to Teufelsburst in 'The Cruel Painter.' While that man drugs his student to inform his artistic explorations of pain, however, the earl is not given any such practical use for his experiments on Donal (and previously on Arctura), seeming to do so purely as a form of personal entertainment. The reader is given no insight into the thoughts and motivations of the earl; instead the events are focalised almost entirely through the character of Donal, and occasionally through Arctura. When Arctura discusses the situation with Donal, she suggests that her uncle drugged her "to see its operation on one who did not even know she had taken anything" (159). Towards the midpoint of the novel, the narrator too attempts to ascribe the following as motivation for his behaviour:

There was hardly any sort of narcotic with which he did not at least make experiment, if he did not indulge in it. He made no pretense even to himself of seeking therein the furtherance of knowledge; he wanted solely to find how this or that, thus or thus modified or combined, would contribute to his living a life such as he would have it, and other quite than that ordered for him by a power which least of all powers he chose to acknowledge. The power of certain drugs he was eager to understand: the living source of him and them and their correlations, he scarcely recognised. (227 italics mine)

\footnotetext{
${ }^{73}$ The description of the earl at this point recalls that of the vampire-like Ash tree in Phantastes: both are characterised by a lack of something essential to humanity.
} 
There almost appears to be a contradiction here in MacDonald's reasoning. On the one hand, the earl is not interested in drugs for their ability to provide him with any sort of "knowledge"; but, on the other, he is "eager to understand" their power. And when it comes to the drugs' effects on other people, he also seems to be acting in the "furtherance of knowledge," a pursuit based in the ultimate Faustian motivation, curiosity. This apparent contradiction reflects MacDonald's own uncertainty in his attitude toward such experimentation. He is clearly interested, at the very least, in differing states of consciousness, which can be further seen in Donal's reaction to his drugged experience: "I had a sense of life and power such as I could never of myself have imagined" (159 italics mine).

The "power" of narcotics both to affect the mind and to attain control over others is compared with that of divine love. The narrator describes the power of God as coming from a "living source" (227 italics mine). This concept contrasts strongly with depictions of the earl in a drugged state. When Donal first witnesses lord Morven's nocturnal perambulations, the description of the latter draws clear and striking associations with aspects of death and decay:

[Morven] looked very white and worn - Donal thought a good deal worse than when he saw him first. His cheeks were more sunken, his hair more gray, and his eyes more weary with a consuming fire in them that had no longer much fuel and was burning remnants. (142)

The idea that the earl is nearing the end of his life, running out of "fuel" as it were, is in sharp contrast to the portrayal of young, fit, and able Donal. Throughout the novel the earl is described in various states of inebriation: to have "lost the power of motion" (240), "with eyes closed breathing heavily" (240), "stretched motionless and pale on the floor" (259), "his face cadaverous; his eyes dull” (265).

\section{"Muscular Christianity": strength in body and soul}

Morven's physical weakness, a clear consequence of his dependence on drugs (despite the fact that he may have initially taken them for health reasons), is repeatedly shown to also be a result of his moral weakness:

On first acquaintance with the moral phenomenon, it had seemed to Donal an inhuman and strangely exceptional one; but reflecting, he came presently to see that it was only a 
more pronounced form of the universal human disease $-\mathrm{a}$ disease so deep-seated that he who has it worst, least knows or can believe that he has any disease, attributing all his discomfort to the condition of things outside him; whereas his refusal to accept them as they are, is one most prominent symptom of the disease. Whether by stimulants or narcotics, whether by company or ambition, whether by grasping or study, whether by self-indulgence, by art, by books, by religion, by love, by benevolence, we endeavour after another life than that which God means for us - a life of truth, namely of obedience, humility and self-forgetfulness, we walk equally in a vain show. (296)

The word 'disease' is repeated four times in the above passage, showing the clear association the term held for MacDonald in terms of both the physical and the moral self. $^{74}$

The depiction of the earl as morally corrupt is reinforced in the novel by a story he tells to Donal of one of his ancestors, "an original savage" (229). This creature was born "by one of those freaks of nature specially strange and more inexplicable than the rest" (229), and his description is one of a monster. In fact, the earl compares him directly to "Mrs Shelley's creation in Frankenstein," and gives just such a fragmentary description of his features as is seen in that earlier novel: "[h] was of gigantic size, with coarse black hair [...] with a huge, shapeless, cruel, greedy mouth, [...] lips hideously red and large, with the whitest teeth inside them" (229). The breakdown of the visage into such fragmented pieces dehumanises the character (a parallel technique previously seen in this capacity in Phantastes, in the description of the demonic Ash), and parallels are immediately drawn between this character and the drug-addled earl describing him. Donal himself "with involuntary insight, saw both cruelty and greed in the mouth that spoke, though it was neither huge nor shapeless" (229). The similarity highlights the moral qualities (cruelty, greed), that the two characters share, rather than any physical resemblance. The creature is "as cunning as he was hideous" (230). It is in his actions, therefore, that the ultimate connection with his descendent appears. We are told that "his great passion, his keenest delight, was animal food" and that he "ate enormously" (229). This gluttony leads him to one day escape his "keeper," abduct a small child, and proceed to cook and eat her. The horror associated with this crime results in "such

\footnotetext{
${ }^{74}$ The association between drug addiction and disease as viewed by contemporary medical thinking will be discussed in the next section.
} 
an outcry that they were compelled to put him in chains and carry him no one knew whither" (230).

The creature's actions are comparable to the earl's own, in the murder of his sons' mother and her baby, and his later attempt to do the same to Arctura. The chaining and incarceration of the beast are mirrored in Morven's own past actions toward the mother of his children. When Donal and Arctura discover the walled-up chamber in which she was incarcerated, they see the body of the dead woman on an ancient bed: "blankets and quilt, sheets and pillows had crumbled with it through the long wasting years" (269). Not only this, but "there was a staple in the post, and from the staple came a chain! -and there at its other end a ring, lying on the pillow! and through it - yes through it, the dust-arm passed!" (270). Morven's chaining and walling-up of his wife becomes thus a symbol of his own moral depravity. His guilt over their illegitimate relationship led to his attempt to lock her away, as his ancestors had the "original savage."

The relationship between moral corruption and ancestry is also present in the relationships between the earl and his sons. Lord Forgue's relationship with Eppy, the castle maid, is evidence of his moral corruption. ${ }^{75}$ When Donal confronts him, the earl's oldest son scoffs, “[w] ould you have me marry the girl?" (123). Donal's reply reveals his strong disapproval of the situation:

What I want is to put a stop to the whole affair. Every man has to be his brother's keeper; and if our western notions concerning women be true, a man is yet more bound to be his sister's keeper. He who does not recognise this, be he earl or prince, is viler than the murderous prowler after a battle. For a man to say 'she can take care of herself,' is to speak out of essential hell. The beauty of love is, that it does not take care of itself, but of the person loved. To approach a girl in any other fashion is a mean scoundrelly thing. (123)

While the scene places Donal and Forgue at odds in light of a moral issue, the crucial scene between them takes place earlier, in the stable yard, when Forgue is mistreating one of his horses. In this situation, too, his behaviour is portrayed as the result of a corrupt nature:

\footnotetext{
${ }^{75}$ This plotline recalls the seduction by Steerforth of "little Em'ly" in Dickens' David Copperfield (1850).
} 
The young lord was a horseman in the sense of having a good seat; but he knew little about horses; they were to him creatures to be compelled, not friends with whom to hold sweet concert. He had not learned that to rule ill is worse than to obey ill. Kings may be worse than it is in the power of any subject to be. (63)

As Forgue raises his arm to give the horse a "useless, cruel, and dangerous blow" (63), Donal rushes to its side. His actions in this scene reveal him to be (like many of MacDonald's characters throughout his novels) sympathetic toward the treatment of animals (horses in particular). The earl's son then turns his rage on Donal himself, bringing down his whip "with a great stinging blow upon Donal's shoulder and back" (64). Donal, however, easily defeats him, as "[t]he fierce blood of the highland Celt rushe[s] to his brain," and he takes him by the leg and throws him down from the horse. While it is not suggested that Forgue is in any sort of ill health as his father is, he is still characterised as physically weak beside Donal. The scene shows that for MacDonald 'might' is the equivalent of 'right.' Donal's physical superiority towards his social betters is necessarily associated with his moral superiority.

Donal's relationship with the earl's younger son, Davie, contrasts sharply with the physical violence that defines his interactions with Forgue. In his role as Davie's tutor, Donal's lessons to the younger boy allow the author to verbally justify his character's behaviour, as well as emphasise his point. "Listen to me," Donal says to Davie:

You didn't think I was afraid of him? [...] I could have killed your brother more easily than held his horse. You don't know how strong I am, or what a blow of my fist would be to a delicate fellow like that. (65)

Donal physically removes Forgue from his horse, but does not actually beat him because, as he tells Davie, "I am not my own master" (65). His master is Jesus Christ, which allows Donal to support his moral position: "He says I must not return evil for evil, a blow for a blow. I don't mind what people say about it: he would not have me disgrace myself!" (65). Donal's moral superiority over Forgue is reasserted by his physical superiority.

The implied connection between the physical body and morality of MacDonald's characters conforms to the nineteenth-century concept of "muscular 
Christianity." The term was coined by T.C. Sanders in a review of a Charles Kingsley novel, Two Years Ago (1857), which appeared in the Saturday Review. ${ }^{76}$ It describes Kingsley as a writer whose "ideal is a man who fears God and can walk a thousand miles in a thousand hours - who, in the language which Mr Kingsley has made popular, breathes God's free air on God's rich earth, and at the same time can hit a woodcock, doctor a horse, and twist a poker around his fingers" (Hall, 7).

While Kingsley himself rejected the term "muscular Christianity," others embraced it, seeing in the movement, as David Rosen notes, "a gentle, liberal but realistic, and hard-working social activism" ("The Volcano and the Cathedral," 17). John Pennington also describes it as “a virile, strong-armed Christianity, a man's religion, so to speak, that melded courage and faith, spirit and body" ("Muscular Spirituality in George MacDonald's Curdie books" 133). ${ }^{77}$

\section{Women and the strength of the spirit}

For MacDonald spirituality seems inextricably connected with the physical nature of humanity. However, the relationship between the spiritual and physical is inverted when applied to MacDonald's female characters. For the female characters in the novel, it is ill health which is associated with positive spirituality. While in Adela Cathcart we saw the young heroine's ill health resulting from a lack of spirituality, which a return to physical health sought to improve, in Donal Grant Arctura's physical health weakens as her spiritual state strengthens (ultimately resulting in her death).

At the start of the novel Arctura is under the negative influence of the parson's daughter, Sophia. MacDonald's choice of name in this instance is interesting, since 'sophia' is the Greek for wisdom. In Paul's first letter to the Corinthians, he writes:

\footnotetext{
${ }^{76}$ See Donald E. Hall's introduction to Muscular Christianity: Embodying the Victorian Age (2006) for more detail on this first usage. The following articles by Rosen and Pennington are chapters from this book.

${ }^{77}$ Interestingly, MacDonald has previously been better known for his depiction of moral strengths rather than physical ones. Pennington writes, for example, that MacDonald "advocates a spiritual muscularity, one that requires strength of spirit rather than a strength of body" (135 italics mine). This is perhaps most evident in his fantasies and stories for children, where the protagonist is quite often young, or weak, or ill. (Diamond in At the Back of the North Wind, for example, is frail and weak and the novel ends with his death, ultimately from malnutrition and neglect.) As suggested in the introduction to this thesis, MacDonald's own ill-health is a likely source for his prioritising of the mental and spiritual over the physical. Donal Grant is all the more interesting in this context.
} 
For it is written, I will destroy the wisdom of the wise, and will bring to nothing the understanding of the prudent. Where is the wise? where is the scribe? where is the disputer of this world? hath not God made foolish the wisdom of this world? For, after that, in the wisdom of God, the world by wisdom knew not God, it pleased God, by the foolishness of preaching, to save them that believe. [...] Because the foolishness of God is wiser than men; and the weakness of God is stronger than men. For ye see your calling, brethren, how that not many wise men after the flesh, not many mighty, not many noble, are called: But God hath chosen the foolish things of the world to confound the wise; and God hath chosen the weak things of the world to confound the things which are mighty; And base things of the world, and things which are despised, hath God chosen, yea, and things which are not, to bring to nought things that are: That no flesh should glory in his presence. (KJV, 1 Cor 1.19-29)

Earthly wisdom, according to Paul, is foolishness in light of divine wisdom. The inverse point was made with reference to the mad laird in the previous chapter. Sophia is thus a worldly parody of "the Divine Wisdom" implied by her name. This juxtaposes neatly with Arctura's own name, similar as it is to that of the constellation Arcturus, found in the heavens. Arctura, as her name implies, is granted heavenly transcendence with her death at the end of the novel.

In the beginning, however, Arctura is at odds with Donal over his teaching of her young cousin, Davie. In their first recorded meeting, she comes across Donal reading from the seventeenth chapter of Solomon's Book of Wisdom (whose title is obviously relevant in this context). This text describes Egyptian prisoners trapped in the darkness by their own sin, "fettered with the bonds of a long night" (Wisdom of Solomon 17:2). The description of the prisoners is clearly applicable to the state of Arctura's uncle, the earl: "For while they supposed to lie hid in their secret sins, they were scattered under a dark veil of forgetfulness, being horribly astonished, and troubled with [strange] apparitions" (17:3). When Arctura hears this passage read aloud, therefore, she is troubled by the conjunction of its Biblical tone, and its merely apocryphal status (75).

The earl, with his dark secrets about the ill-treatment of his wife, is haunted by "strange apparitions," the results of guilt and brooding, intensified by his use of opiates. $^{78}$ Arctura's recognition of her uncle in the description read by Donal

\footnotetext{
${ }^{78}$ This aspect of the earl's suffering will be gone into in more detail later, as part of a discussion of brain activity and mental hauntings.
} 
compels her to reconsider her opinion of him and to join Davy as his pupil. By the end of the novel, however, when she and Donal are united in marriage (a purely spiritual union as it remains unconsummated), Arctura's health has declined rapidly and she dies shortly after. For her, physical health has an inverse relationship to that of spiritual health. ${ }^{79}$

\section{Narcotics and morality}

The male-female complication aside, the parity between the physical and the spiritual is maintained in other aspects of the novel. MacDonald's portrayal of drug addiction shows an appreciation of current attitudes towards both opiate use and morality. Physical addiction was seen as a disease of the will. Treatment focused, therefore, on what was thought of as the moral weakness (or even insanity) of the patient. As Donal describes lord Morven: “[T] he earl's madness was the worst of any, a moral madness" (372). MacDonald builds on a contemporary distinction between the 'morphinist' (a sufferer who wanted to be cured and would assist in a planned withdrawal of the drug) and the 'morphinomaniac,' (who did not want to be cured and was therefore treated as a lunatic). Lord Morven is one of the latter, since he has to be forced into rehabilitation by Donal and the doctor:

[Donal] trusted Mr Avory would give his sanction to the entire disuse of [the drugs], for they were killing [the earl] body and soul.

"To give them up at once and entirely would cost him considerable suffering," said the doctor.

"He knows that, and does not in the least desire to give them up. It is absolutely necessary he should be delivered from the passion. (370)

The sort of patient depicted in the character of lord Morven would have been subjected to just such an 'abrupt' mode of treatment. While not in the slightest viewing the condition as a "true mental disorder," Levinstein, too, saw addiction as a

\footnotetext{
${ }^{79}$ The ending also conforms to MacDonald's reluctance to portray a conventional happy ending when a relationship involves a difference in class. This can perhaps be explained by Wolff's claim in The Golden Key that MacDonald himself fell in love with a girl of the aristocracy, while working in the library of a castle during a break from university. She apparently led him on and then spurned him, which Wolff suggests led to the plethora of unhappy endings involving such relationships in his novels. Adela Cathcart is clearly an exception to this, but as such an ending is so crucial to the main plotline it clearly could not be avoided. We do, however, get the bizarre dream sequence involving the narrator himself, who, as a MacDonald figure, does fulfil the requirements for an unhappy union on earth, but a more promising afterlife.
} 
"human passion," similar to "smoking, gambling, greediness for profit, sexual excesses etc..." (7). Levinstein's description, in his Morbid Craving for Morphia, of the addict's treatment by medical professionals (involving strict solitary confinement in a locked and barred room) does much to reveal the harshness of such 'abrupt' methods of treatment over gradual withdrawal. But this essentially primitive method was so favoured by English specialists that it eventually became known as the "English treatment" (Berridge and Edwards, 160). In fact, the general move to abrupt withdrawal from earlier, more gradual regimes projects a stricter, moral, reaction to the condition. The categorisation of morphine addiction as a bad habit seemed to justify treatment in the form of punishment. This view is clearly seen to be shared by MacDonald is his portrayal of the relationship between Morven and Donal.

As the patient's condition was seen to be the result of some personal moral failure, the cure was similarly thought to necessitate a change in certain personal characteristics. The inebriate's conscience was therefore to be approached by supplications to a sense of family and community duty. The moral leadership of the specialist was similarly crucial, and we can see this reflected in the relationship described by MacDonald as existing between Donal and the dying earl. In the chapter entitled "A Moral Fungus," for example, the earl's condition is put down to qualities such as, "[s]piritual insanity, cupidity, cruelty, and possibly immediate demoniacal temptation" that have "long been working in and on a mind that had now ceased almost to distinguish between the real and the unreal" (350). The idea of the earl as suffering from a "moral fungus," lends a physical quality to what would otherwise be thought of as spiritual. The reference to the inability to distinguish between "the real and the unreal" also draws attention to the site of this "infection" as in the mind, the organ mediating between the physical and the spiritual.

The earlier story of his ancestral cannibal is told by the earl himself towards the end of the novel, as his condition worsens. It thus works as a confession or acknowledgement of his sins, and it is, significantly, divulged to Donal. In contrast to the earl, Donal has been a moral yardstick throughout the novel, one against which the morality of the other characters is to be measured, and from which an example should be taken. Up until the end of the novel this lesson has been primarily taken up by Davie and Arctura, Donal's 'students', but by the end it is the earl who 
perhaps benefits most in MacDonald's eyes through his redemption and final acceptance of God before death:

[T] he wretched man burst into tears, and the heart of Donal gave a leap for joy. [...] [Y] et was that weeping some sign of contact between his human soul and the great human soul of God; it was the beginning of a possible communion with the Father of all! (377)

The earl is rewarded for his withdrawal from his precious drugs by that prize which MacDonald values perhaps above all: death with the understanding of eternal life. His death is compared to that of his niece, Arctura, both having been transformed by their relationship with Donal. As Arctura says to Donal on her own deathbed, "if it hadn't been for you, God would have been far away still! For a God I should have something half an idol, half a commonplace tyrant!” (378). ${ }^{80}$

\section{Drugs and the "constructive mind"}

The similarities between MacDonald's text and those of contemporary physicians extend beyond the moral issue. The symptoms MacDonald uses to characterise the earl in his addiction also correspond to those reported in the medical literature. Morven's health fluctuates, the narrator reports, “depending very much on the special indulgence" (228):

The one day he was better, the other worse, according, as I say, to the character and degree of his indulgence. At one time it much affected his temper, taking from him all mastery of himself; at another made him so dull and stupid, that he resented nothing except any attempt to rouse him from his hebetude. (228)

F. E. Anstie describes, in Stimulants and Narcotics (1864), one of his patients in a similar fashion. He notes that the symptoms of narcosis recovery include "giddiness," "muscular tremor," "headache, stupidity, dyspepsia, and depression" (220). These responses are also, he notes, "the ordinary after consequences of the professed opium-eater, in the intervals of his debauches" (220). Anstie goes on to discuss another sufferer of opium-narcosis, for whom "a constant sense of profound melancholy brooded over his mind, both in sleeping and waking moments" (179).

\footnotetext{
${ }^{80}$ Furthermore, Donal's involvement in the earl's rehabilitation recalls MacDonald's consistent concern with doctor-patient relationships. See, for example, the previous chapter on Adela Cathcart.
} 
Not only this, but "[h]is perceptions of time and space were altered in a way which caused natural objects, and periods of time, to be enormously magnified to his imagination" (179). De Quincey, too, claims that "[t]he sense of space, and in the end the sense of time, were both powerfully affected [...] Space swelled and was amplified to an extent of unutterable and self-repeating infinity. This disturbed me very much less than the vast expansion of time" (224). Such perceptions of time and space also play a significant role in the Donal Grant.

Significantly, however, in terms of MacDonald's use of drugs and their effects in the novel, it is Donal who reports such an experience, and not while under the influence of a narcotic. When he first arrives at the castle, for example, "such a stair as in wildest gothic tale he had never imagined. Like the revolving centre of a huge shell, it went up out of sight, with plain promise of endless convolutions beyond" (45). When he first sees the view from his tower window, furthermore, his exclamation is "I thought I was in eternity" (50). Time, too, is from the start a preoccupation with sober Donal. He thinks to himself:

The relations of time to mind are very strange. Some of their phenomena seem to prove that time is only of the mind belonging to the intellect as good and evil belong to the spirit [...] But the mere notion of time, not to say the consciousness of empty time, is fearful. (54-5 original italics)

Later, when he is wandering the castle at night in pursuit of a ghostly sound, time is again foremost in his mind: "Then again the moments were the small cogs on the wheels of time, whereby the dark castle in which he sat was rushing ever towards the light: the cogs were caught and the wheels turned swiftly, and the time and the darkness sped" (55). ${ }^{81}$ For MacDonald, changes in perception of time and space are clearly not just detrimental effects of drug use. They are a means by which a character is shown to have depth and a "constructive mind" (135). Donal's strength of character is not maintained merely through physical health, then. His spiritual strength allows him access to such visions that other characters, such as the earl, require drugs to reach. Donal's portrayal at such times complicates MacDonald's attitude to drugs in the novel. The author's interest in the mind as an intermediary between the physical and the spiritual is informed by its response when under the influence of narcotics.

\footnotetext{
${ }^{81}$ Note again the idea of the mechanical used here to suggest Donal's experience of time and space.
} 
Not only do MacDonald's portrayals of Morven's dependence on drugs, and Donal's enforcement of a rehabilitation program, reflect contemporary medical views on the condition, they also bear striking resemblance to those biographical accounts given by de Quincey, in his Confessions of an English Opium-Eater (1856), and by the Romantic poet, Coleridge. The descriptions of the earl's state of mind during the times in which he is under the influence of opiates shows MacDonald's fascination with the workings of both the human mind and brain, especially through the relationship between hallucination and fantasy. This is especially prevalent in his focus on the subject of ghosts and hauntings. But he maintains a moral attitude to the state despite his enthusiasm, using the concept of the self to anchor his portrayal.

MacDonald goes into great detail when he describes the drug-induced condition in which the earl wanders the castle. The first instance, on Donal's first night in the castle, fills three pages, and emphasises the aural and visual hallucinations which the earl experiences. When the earl too hears the mysterious sound haunting the castle, he hears it first as the voice of his dead wife, "the song of the eternal woman," followed by "the wind in the tree of life" (136). The hallucination then undergoes a transition into a visual form as the notes are transformed into "colours" and "flowers," culminating in the earl's exclamation that, "I can see them as they grow, as they blow! [...] No, that flower is not a note! It is a chord! - and what a chord! I mean, what a flower!"

De Quincey too describes this experience along with the following explanation:

$[\mathrm{I}] \mathrm{t}$ is by the reaction of the mind upon the notices of the ear (the matter coming by the senses, the form by the mind) that the pleasure is constructed; and therefore it is that people of equally good ear differ so much in this point from one another. Now opium, by greatly increasing the activity of the mind, generally increases, of necessity, that particular mode of its activity by which we are able to construct out of the raw material of organic sound an elaborate intellectual pleasure. (Confessions, 179)

The collaborative effect of the physical senses with the intellect of the mind results in individual interpretations of material. The use of opium exacerbates the situation and in the case of the earl the brain's interpretive function of sensory material has become confused. Not only does the earl see visions that, as far as Donal is 
concerned, only he can see, but the sounds too become entirely based in the brain: "From his words he seemed still to be hearkening the sounds aerial, though to Donal at least they came no more" (136). De Quincey goes on to describe his own experience thus, elaborating on the idea that under the influence of such a narcotic as opium the operations of the brain and the imagination become interconnected: "[A]s the creative state of the eye increased, a sympathy seemed to arise between the waking and the dreaming states of the brain in one point - that whatsoever I happened to call up and to trace by a voluntary act upon the darkness was very apt to transfer itself to my dreams" (224).

It is not long after this episode that Donal finds himself experiencing the effects of a strong dose of narcotics. The earl invites him to dinner, and after some polite conversation about Davie's academic progress so far, offers him some wine from the decanter on the table. Donal finds himself accepting, though acknowledging that he has "drunk so little wine that I do not know one sort from another" (146). The effect on him is described as a "sudden change":

[S]omething seemed to give way in his head - as if a bubble burst in his brain, and from that moment whatever the earl said, and whatever arose in his own mind, seemed to have outward existence as well. He heard and knew the voice of his host, but seemed also in some inexplicable way, which at the time occasioned him no surprise, to see the things which had their origin in the brain of the earl. Whether he went in very deed out with him into the night, he did not know - he felt as if he had gone, and thought he had not - but when he awoke the next morning in his bed at the top of the tower, which he had no recollection of climbing, he was as weary as if he had been walking the night through. (147)

The drugs have the effect of giving physical form to mental phenomena: not only do his own thoughts develop "outward existence," but so do the earl's and, in a later experience, even animals. During the second occasion on which Donal drinks the drugged wine, "[h]e seemed to be reading the thoughts of his sheep" (154).

The form which the earl's hallucinations and visions take is bound up with the guilt he feels over the ill-treatment and eventual murder of his wife: "his conscience was haunted with his cruelties to the youth's mother. [...] In the horrible presentments of his drug-procured dreams they returned upon him in terrible forms 
of righteous retaliation" (297). De Quincey too writes of the relationship between events in reality and those occurring in the dream world which is fuelled by opium:

But naturally these dreams, and this dream-scenery, drew their outline and materials - their great lights and shadows from those profound revelations which had been ploughed so deeply into the heart, from those encaustic records which in the mighty furnaces of London life had been burnt into the undying memory by the fierce action of misery. And thus in reality the early experiences of erring childhood not only led to the secondary experiences of opium, but also determined the particular form and pressure of the chief phenomena in those secondary experiences. (201)

Both authors write in terms of the brain's physical response to experience, using such terms as 'encaustic' to represent the idea that events are burned into the memory, thus enabling them to return in dream form. This idea is not a new one. Earlier in the nineteenth century, as Michael S. Kearns writes, Coleridge had compiled a list of the dominant metaphors of mind used by psychological philosophers of the eighteenth century (Metaphors of Mind, 1), accusing them of standing in the way of "a clear presentation" (2) of the mind's activities. Despite this, such language continued to be used. Thomas Reid, in his first major publication, An Inquiry into the Human Mind (1764), describes thoughts as "impressing agents" (Kearns, 8). Reid likens the mind of a child to "a piece of clay" as able to be imprinted upon and retain impressions. An adult's mind, likewise, contains "tracks" along which already known thoughts can progress smoothly and without hindrance. Both MacDonald's and de Quincey's descriptions of the relationship between the real-life experience and the dream re-enactment share this vision of actual impressions formed physically in the mind.

\section{MacDonald and the sensation novel}

This intense interest on the part of MacDonald in the almost scientific aspects of drug use connects him with other authors of the sensation novel at this time. Wilkie Collins, for example, in the enormously popular The Woman in White (1860) and The Moonstone (1868) makes use of a number of similar plot devices. The medical (ab)use of opium is crucial to the unveiling of the mystery in The Moonstone, as is the condition of somnambulism while in such a state. In Collins' novel, Ezra 
Jennings' addiction to opium, after using it for many years to treat "an incurable internal complaint" (375), has resulted in a "shattered" nervous system, and "nights of horror" (375). But it is his knowledge of the effects of the drug that enables him to solve the mystery of the missing moonstone. He realises that it must have been while "in a state of trance, produced by opium" (380) that Mr Blake took the diamond from Miss Verinder's sitting-room, hence his lack of memory concerning the incident. Working with such a hypothesis he devises an experiment whereby Blake is again drugged in the hope that he will repeat his earlier actions: "we may fairly hope that a repetition of the dose will lead, in a greater or lesser degree, to a repetition of the result" (384). Mr Jennings is similarly interested in levels of consciousness and memory, quoting directly from nineteenth-century physician, William Benjamin Carpenter (1813-1883):

There seems much ground for the belief that every sensory impression which has once been recognised by the perceptive consciousness is registered (so to speak) in the brain, and may be reproduced at some subsequent time, although there may be no consciousness of its existence in the mind during the whole intermediate period. (385, original italics)

This concept underlines Jennings' theory that Blake will remember his previous actions when under the influence of the narcotic when that mind-state is re-induced.

In a similar way, the earl's actions while under the influence of his narcotics also reflect a theory of differing mind states. On each occasion on which Donal comes across the earl in a trance, much is made of the fact that the earl does not see, let alone recognise him. In fact, the difference between the earl in this state and in his normalcy is strengthened by a shift to his depiction as an object: he becomes "the apparition" (136), and is referred to by the nominative "it" rather than "he":

The apparition turned its head towards him; but in its look was no atom of recognition, no acknowledgement or even perception of his presence; the sound of his rising had had merely a half-mechanical influence upon its brain. It turned away immediately, and went on to the window. There it stood, much as Donal had stood a little while before. $(136)^{82}$

\footnotetext{
${ }^{82}$ The reduction of the earl to something mechanical recalls the incident in the earlier Malcolm (discussed in the previous chapter), in which the protagonist comes across the dummy in the arbour. The earl under the influence of drugs is no longer conceived of as human, and thus MacDonald's portrayal of this state once again invites contemplation of the condition.
} 
In a later incident, the earl once again does not see Donal or Arctura (who has accompanied him), "or if he did, he saw them but as phantoms of the dream in which he was walking - phantoms which had not yet become active in the dream" (191).

MacDonald takes this idea one step further, however, in his incorporation of the spiritual alongside the physical. The earl, for example, in his explanation to Donal of how he first came to use opium, suggests that one of its benefits is to not merely access another state of consciousness, but to become "free from the body, that is from the dilapidated brain" (292). Donal refuses to abandon the significance of the brain, however, arguing, "what if the brain give the opportunity for the action which is to result in freedom? [...] Think for a moment what we should be without the senses" (292-3). But the senses, for Donal, are a means of connecting with the spiritual; they are, he claims, "only the husks under which are ripening the deeper, keener, better senses belonging to the next stage of our life" (293).

\section{"Home-born phantoms": a creative madness}

The earl's desire to become "free" from his "dilapidated brain" (292) speaks to his painful memories regarding his treatment of Forgue's mother. His guilt over his abuse of that woman is the primary impetus behind his drug-fuelled delusions: his conscience is "haunted" by her memory (296). His delusions, however, are not only based in actual recollection. They also contain a creative element as seen in the earl's earlier interpretation of the mysterious sounds he hears as first the voice of his wife, and then a visual illusion of blooming flowers: "In his being, a world of false appearances had taken the place of reality; a creation of his own had displaced the creation of the essential Life $[. .$.$] and in this world he was the dupe of his own$ home-born phantoms" (297). Such creation is for MacDonald linked to the action of the devil. As the earl himself puts it on his deathbed, "It was those cursed drugs that wiled the soul out of me, and then the devil went in and took its place! (372). Donal too views the earl's condition as a madness produced by the devil. When he and Arctura discover the hidden room where the earl had imprisoned the mother of his two sons, he claims, "I suspect [the earl] is more of a madman than we knew. I wonder if a soul can be mad. - Yes; the devil must be mad with self worship! Hell is the great madhouse of creation" (350). 
As von Schubert posits in Die Symbolik des Traumes, man's conscience can also be manipulated by a low, evil world of spirits, (ab)using the same imagery or symbolism (80). Our conscience and our imagination are thus ambivalent tools, capable of both good and evil. MacDonald too recognises the negative potential of the imagination. In his essay "The Imagination: Its Functions and Its Culture," MacDonald argues for just this possibility: in the case of mistreatment, "the imagination will yet work; and if not for good, then for evil; if not for truth, then for falsehood; if not for life, then for death; the evil alternative becoming the more likely from the unnatural treatment she has experienced from those who ought to have fostered her" (A Dish of Orts 26). In the case of the earl's use of drugs, the creative function of the imagination has become distorted, making of him "a dupe of his own home-born phantoms" (297).

Contemporary medical literature also mentions this creative element of drug use. According to F.E. Anstie, in Stimulants and Narcotics (1864), the situation is significantly similar to "a considerable number of maladies, in which the brain is unable to perform its highest functions" (176). In such cases, that of "voluntary, or as we might call it creative, recollection" gives "evidence in a remarkable degree of that passive memory which we have seen displayed in narcosis" (176). He goes on to state that " $[\mathrm{w}]$ hatever the exact nature of the process may be, it seems to resemble the uncovering of the older inscriptions of a palimpsest by some agency when destroys the later and more superficial writing." Here again we see reference to the concept of the "palimpsest" or reusable trace element associated with the mind. Anstie also compares the effects of opium-narcosis, including hallucinations and illusions, to a "power possessed by children" of "painting" images on the darkness surrounding them: "In some that power is simply a mechanic affection of the eye; others have a voluntary or semi-voluntary power to dismiss or summon such phantoms" (179).

The idea that such visions are somehow a "mechanic" function of the body, in this case the eye, relates to the interest MacDonald and de Quincey show in the physical effects of drug use. But the term "phantoms" to describe the result carries with it the necessary association of haunting. According to the $O E D$, a "phantom" is primarily defined in terms of "illusion, unreality; emptiness, vanity; delusion, deception, falsity" (n.1.a.). The second definition of the word, however, invokes a more figurative interpretation: "A thing (usually with human form) that appears to 
the sight or other sense, but has no material substance; an apparition, a spectre, a ghost" (n.2.a.). As previously mentioned, the earl's visions obtained under the influence of his narcotics frequently involve the memory of his dead wife. In this sense, haunting becomes an act that takes place within the mind of the individual. While Teufelsburst, in 'The Cruel Painter,' erroneously believes that he is being haunted by the ghost of Karl (when in actual fact it is Karl himself, alive and well), lord Morven is also not haunted by a literal ghost, but rather by the memory of his own past cruelty. In many ways, the story of the earl is an exaggerated version of that earlier portrayal of the painter. Because Teufelsburst does not use the drugs himself, only experimenting with them on others, his "cure" does not involve his own physical body. Instead, the narrator tells us, "the shock [of discovering that Karl is alive] had acted chiefly upon that part of his mental being which had been so absorbed. He would sit for hours without doing anything, apparently plunged in meditation" (Adela Cathcart 378-9). But in the case of Donal Grant, the earl's addiction involves not only the observation of the drugs' effects on others around him, but also his own (repeated) physical experience of them. So too, then, must his cure: the complete withdrawal of all drugs from his system, as brought about by Donal, which ultimately results in his death.

The death of the physical body as the result of this cure, and as one known and accepted by Donal, highlights MacDonald's ongoing agenda of spiritual transcendence. It is the redemption of the earl's soul that enables the success of Donal's intervention; as it was for the hunchbacked Stephen Stewart in Malcolm, the physical body is a mere temporary burden to be shed at death. Despite MacDonald's emphasis on physical superiority coinciding with spiritual health in the character of Donal himself, when it comes to the ultimate crux between the two spheres, it is the physical that is sacrificed. This conclusion is reinforced by Donal's renunciation of the castle and its estate (despite his legal status as Arctura's heir). As in the instance of the titular hero of the earlier Wilfrid Cumbermede, worldly wealth is renounced to make way for the development of the spiritual self. As Donal himself puts it towards the end of the novel, "I must inherit the earth in a far deeper, grander, truer way than calling the land mine, before I shall count myself to have come into my own" (392). 


\section{Chapter Six: \\ "A Darkness that Haunts": a guilty mind in \\ The Flight of the Shadow}

\section{Introduction: a haunting parable}

The Flight of the Shadow (1891) is a novel about guilt and the consequent fracturing of self. Edward Whichcote lives a divided life: one half in the quiet company of his loving niece, Belorba, and the other wandering the moors alone. His behaviour is caused by mental guilt - the dark secret that Belorba realises her uncle holds within him. Whichcote recalls characters in the earlier novels who are similarly plagued by obsession (such as the drug-abusing lord Morven and the mad laird, Stephen Stewart). The theme of obsession and its effects are underlined through Gothic elements; in particular the arrival of Edward's "haunting" double, his twin brother Edmund. The focus on doubling suggests the influence of E. T. A. Hoffman and in particular his story 'The Sandman.' In the form of Edward's long-lost brother, his double becomes a symbol of the past, while the character of lady Cairnedge (over whom they became enemies) embodies that "carnage" living on in the present. ${ }^{83}$ The separation of the twins, furthermore, suggests a division of self, and their reconciliation at the end of the novel is a return to individual wholeness as well as brotherly reconciliation.

The Flight of the Shadow is one of the author's less-discussed novels, and this can perhaps be attributed, at least in part, to the relatively skeletal nature of its plot and schematic. William Raeper makes a number of brief references to the text, but always in the context of other more popular novels. For example, in discussing the tendency of the author's later texts to favour romance over reality, Raeper describes The Flight of the Shadow as "pure romance" $(203,209)$. Rolland Hein in The Harmony Within has one sentence on the text, and an unflattering one at that, describing it as "obviously too quickly written and of inferior quality" (22). David S. Robb (George MacDonald) omits any mention of the novel whatsoever, and not

\footnotetext{
${ }^{83}$ See page 15 , note 19.
} 
one of the essays included in Jean Webb's "A Noble Unrest”: Contemporary Essays on the Work of George MacDonald refers to it. Elizabeth Saintsbury, in George MacDonald: A Short Life, does argue that "some of [MacDonald's] best books" belong to the period in which it was written (the last decade of the nineteenth century), but she too leaves The Flight of the Shadow out of her selective bibliography of MacDonald's titles. MacDonald himself was perhaps ambivalent about the text. In a letter to his eldest daughter, Lilia, on 4 January 1891, the year of its publication, he writes that he has "still one great poem in my mind, but it will never be written, I think, except we have a fortune left us, so that I need not write any more stories - of which I am beginning to be tired" (Sadler 343). John Docherty, in his essay “An Ambivalent Marriage of Heaven and Hell” (in McGillis 2008), stands perhaps alone when he points out in a footnote the fact that the novel contains a "beautiful parable" (131n). More comprehensively, Jennifer Koopman, in her 2006 thesis Redeeming Romanticism: George MacDonald, Percy Shelley, and Literary History, argues convincingly for a reading of the novel as a precursor of Lilith, on the grounds that - like Lilith - it contains portraits of the Romantic poet in the characters of Edward Whichcote and Mr Raven. Koopman discusses the novel, as she does with the others included in her thesis, in terms of "literary history": considering "how subsequent generations may escape a troubled past" (205). I would agree with this insightful reading, but choose instead to focus on the personal, the more psychological aspects associated with family genealogy.

The novel is narrated in the first person by Belorba Day, and is one of only two novels MacDonald wrote that feature a female narrator. ${ }^{84}$ It does, however, share a number of features with the novels previously discussed. Like the protagonists of Phantastes, Wilfrid Cumbermede, and Malcolm, Belorba is an orphan (she tells us in the first chapter that her name literally means "Fair Orphan," 4), and the story follows her childhood, growing up with an uncle, the elder brother of her father. As she grows older she becomes aware that there is something troubling her uncle, and the novel takes on the form of a mystery (as does Wilfrid Cumbermede, and, to a lesser extent, Malcolm), as both Belorba and the reader seek to discover the source of her uncle's depression.

\footnotetext{
${ }^{84}$ MacDonald's other female narrator is Ethelwyn Walton in The Vicar's Daughter (1872).
} 
The Flight of the Shadow can thus also be read as similar in subject matter to Adela Cathcart, in that it sets up a pathology of the individual, but the relationship between trauma and therapy differs significantly in the two novels. While in each case a cure involves the transmission of narrative, for Adela healing is achieved through identification with the stories of others. For Edward Whichcote, on the other hand, healing begins with his own confession in the form of a letter to his niece.

The setting of the novel, while perhaps not as explicit an externalised landscape of the mind as that seen in Phantastes, is nevertheless pertinent to the novel's exploration of the human psyche. The architecture of the Whichcotes' house, for example, is given considerable attention, and the similarities drawn between it and its master invite a psychological reading. ${ }^{85}$ Furthermore, the two households introduced, that of the Whichcotes, and of "Rising" (the home of Lady Cairnedge and her son, John Day) comprise almost the only characters in the novel, and for much of the narrative the characters remain isolated in an almost fable-like setting, isolated from reference to a wider society. ${ }^{86}$

\section{A portrait of depression}

Edward Whichcote, returning from Germany to look after his dead older brother's interests, is seen by his niece as "father and mother and everybody" (50). His suffering is at once magnified and obscured by this emotional lens, as Belorba's love for her uncle both prompts her to explore and to avoid aspects of his thought and behaviour. We are first made aware that something is wrong with Edward in the third chapter, with Belorba's initial description of him: "[ $\mathrm{t}]$ he first thing that would have struck you about him would have been, how tall and thin he was. The next thing would have been, how he stooped; and the next, how sad he looked" (7). But attention is immediately withdrawn from this aspect of his character, by Belorba's exultant praise, as she goes on to claim, "I never thought of analysing his appearance, never thought of comparing him with anyone else. To me he was the best and most beautiful of men - the first man in all the world" (original italics). Nevertheless, it soon becomes apparent that her uncle's life is divided: between his time spent in the company of his niece, and that alone, walking or riding on the

\footnotetext{
${ }^{85}$ This relationship will subsequently be explored in more detail.

${ }^{86}$ In this sense the setting of the novel recalls Emily Brontë's Wuthering Heights (1847).
} 
moors. Belorba reports that while "he always made me welcome to share his room with him [...], he seldom took me out walking" (7). But while she observes these aspects of her uncle's mood and behaviour (and accompanying state of mind), she resists an active exploration of its cause:

Occasionally [...] he would occupy a large old-fashioned easy chair, under the slope of the roof, in the same end of the room, sitting silent, neither writing nor reading, his eyes fixed straight before him, but plainly upon nothing. They looked as if sights were going out of them rather than coming in at them. [...] I do not remember the time when I did not know that his face was troubled. It gave the last finishing tenderness to my love for him. It was from no meddlesome curiosity that I sat watching him, from no longing to learn what he was thinking about, or what pictures were going and coming before the eyes of his mind, but from such a longing to comfort him as amounted to pain. (12 italics mine)

While Belorba's observance of her uncle in such states is attributed not to any "longing to learn what he was thinking about," this nevertheless becomes the impetus behind the plot of the novel. She notes that, while Martha Moon (a distant relative and their housekeeper) ascribes her uncle's "depression" to the death of Belorba's father, "it lasted too long to be so accounted for" (13). ${ }^{87}$ She comes to her own conclusion, that "the soul of my uncle was harassed with an undying trouble, that some worm lay among the very roots of his life" (13).

MacDonald uses a number of such biological metaphors in describing the consequences of holding a secret: Belorba feels about her uncle that "[s]ome worm lay at the very roots of his life" (13), and he himself warns her to "[n]ever let anything that makes itself a nest in your heart, grow into a secret, for then at once it will begin to eat a hole in it" (13). As such, the description recalls William Blake's 'The Sick Rose':

O Rose, thou art sick!

The invisible worm That flies in the night, In the howling storm,

\footnotetext{
${ }^{87}$ Belorba's wording in describing this episode is significant, I think. Martha does not simply say, but "implies" the source of Edward's depression to be her father's death. Once it is revealed that he is living with the memory of his twin brother's death (and himself responsible), it seems more likely that it is this brother about whom Martha spoke. Martha reveals "no surprise," for example, when the two brothers are reunited in Versailles. The incident raises questions about the role Martha Moon plays in the story that are beyond the scope of the present discussion.
} 
Has found out thy bed

Of crimson joy:

And his dark secret love

Does thy life destroy.

(italics mine)

Edward Whichcote's condition is likened thus to a parasitized plant, having a worm at its "root," or core. A secret, MacDonald goes on to tell us, is "a mole that burrows," and "a treacherous, poisonous guest that [eats] away the life of its host" (14). Unlike Adela Cathcart then, Belorba's uncle is ill from the presence of something, rather than an absence that can be filled with narrative. For Edward Whichcote, narrative is a means of release or of purging.

While biological metaphors prove dominant in Belorba's interpretation of her uncle's illness, his depression is also depicted as stemming from a "darkness that haunted him" (13). Such darkness of mood is reflected in the landscape of the novel. When Belorba describes his habit of walking out alone, for example, she says, "I had soon observed that in gloomy weather he went out often, in the sunshine seldom" (7). $\mathrm{He}$ is also regularly out at night, the darkness clearly complementing and perhaps feeding his depressed mental state. The landscape of the novel as a reflection of his peculiar state of mind is similarly evident in the architecture of the Whichcote house. As in many of his novels, MacDonald takes particular care in describing the house in which his character lives. Belorba asserts that her uncle's own room, in "[b]oth its nature and situation [was] in keeping with certain peculiarities of [his] mental being" (8). This room is built into the house in such a way that the entry point is concealed: "[y]ou could hardly have found the way to it, even had you set yourself seriously to the task" (10). And although the house itself is several generations old, the construction of the secret room was "my uncle's contrivance" (10), and it is likened to those built in "troubled times when a good hiding-place would have added to the value of any home" (10). The idea that Edward is in need of a "good hiding-place" because of "troubled times" reinforces a psychological reading. It is significant that this secret room is the location for Belorba's discovery that what her uncle is troubled with is also "a secret" (14). 


\section{Secrets and sins}

Belorba's realisation that her uncle is burdened by a secret is narrated in terms of the biblical Fall. Belorba is tempted to "sin" (16) when she sees her uncle looking at something red and shiny in a drawer. While her uncle has never expressly forbidden her to look in the cabinet, "[s]omehow I seemed to understand that I had no right to know what it was, seeing my uncle had not showed it to me" (15). Nevertheless she does look into the drawer and the intensity of her resulting guilt is surprising: she describes it as "the evil act" reached by treading "the evil path," and once she has done it she shuts the drawer, "and knew that Eve had eaten the apple" (16). ${ }^{88}$ Her guilt, furthermore, plunges her into a fit of depression, recalling her uncle's own, in which she can no longer see beauty in the world:

the first thing, I think, that I grew conscious of, was dreariness. There was nothing interesting anywhere. [...] There was nothing to do, nothing to think about, not a book worth reading. Story was suddenly dried up at its fountain. Life was a plain without water-brooks. If the sky was not 'a foul and pestilent congregation of vapours,' it was nothing better than a canopy of gray and blue." $(16)^{89}$

Belorba's description of her own "sin" clarifies the parallels between this incident and her uncle's depression. It is the fact that it is "his drawer" (17, italics mine) that makes of what she has done "an evil thing." 90 The suggestion is that she has been looking into his secret, into the privacy of his mind, and this is made especially apparent in the final stages of the book, when we learn that the red stone, the subject

\footnotetext{
${ }^{88}$ With this explicit reference to 'the fall,' The Flight of the Shadow makes an interesting contrast to the earlier Wilfrid Cumbermede. In that novel, the young protagonist finds himself in a similar situation of temptation. For Belorba, it is knowledge itself that takes the place of the apple, knowledge, furthermore, of one whom she sees in a God-like aspect. He is, after all, "father and mother and everybody" to her. The effect of this shift in focus from Belorba to her uncle reflects a shift with this novel in MacDonald's wider vision. While Wilfrid Cumbermede holds to the bildungsroman tradition (also found in Phantastes and Adela Cathcart), following closely the selfdevelopment of the young central character, Flight deviates from this path in its interest in the older uncle-figure. In doing so it inverts the situation in Adela Cathcart: uncle and niece have exchanged their roles of investigator and subject.

${ }^{89}$ The quote Belorba uses here is from Hamlet II. 2

90 There is an interesting inverse parallel to be found in Eliot's Middlemarch, where Mrs Plymdale asserts that Mrs Bulstrode could not have been privy to her husband's secret past, that she is "as open as the day. You might look into her drawers when you would" (Ch. LXXIV).
} 
of Belorba's curiosity, had belonged to his brother Edmund, and that Edward has kept it as a reminder of his guilt. ${ }^{91}$

Belorba's concern with concealing her sin foreshadows the revelation of her uncle's secret. While Belorba's sin finds a symbol in the "beautiful" (20) red jewel, that of her uncle lies in the character of lady Cairnedge herself, "the most beautiful woman he had ever seen" (158). Physical passion, the emotion she inspires in Edward to an almost pathological degree, is commonly associated with the colour red. Indeed, lady Cairnedge, in her seduction of Edward, suggests the Whore of Babylon, who, in the book of Revelation, not only rides upon a "scarlet beast," but is "arrayed in purple and scarlet colour, and decked with [...] precious stones" (KJV Rev 17:3-4 italics mine).

Edward's revelation of his past disastrous relationship with the woman, furthermore, takes the form of a confessional letter to his niece. When he gives Belorba the letter, the conversation between them reflects one between a penitent and his priest. He requests that she "pardon" him once she has read his words (118), inverting the previous scenario in which she felt the need to confess to him. Then it had been Belorba asking for her uncle's forgiveness in a scene even more evocative of a confessional:

He walked to the old chest under the gable-window, seated himself on it, and set me down beside him. I slipped from the chest, and knelt on the floor at his feet, a little way in front of him. I did not touch him, and all was again quite dark between us.

I told him my story from beginning to end, along with a great part of my meditations while hesitating to do the deed. I felt very choky, but forced my way through, talking with a throat that did not seem my own, and sending out a voice I seemed never to have heard before. (20)

Just as the act of confession is thought to absolve the sin, so does the revelation of their respective secrets ease the guilt of Belorba and Edward.

\footnotetext{
${ }^{91}$ The incident reveals a further inward shift of MacDonald's architectural metaphor of mind: from the house itself, to the secret room, to a piece of furniture within the room. The description can thus be compared to the scene in which Anodos discovers his father's secretary and enters Fairy Land. One of the crucial differences between the two narratives is the move, in Flight, away from the young narrator and towards the older character, the source of personal history. It is tempting to read this shift as a natural consequence of MacDonald's own advancing age. While Phantastes was published when the author was just thirty two, he was nearly seventy when he wrote The Flight of the Shadow.
} 


\section{E. T. A. Hoffman and the divided self}

The idea of a secret as a means of dividing individuals is central to The Flight of the Shadow. Because of their respective secrets, Belorba and her uncle feel cut off from each other, and from other people. While Edward wanders the moors alone, Belorba too isolates herself, sitting "the rest of the day alone in that solitary room, away from Martha and Rover and everybody" (17). Such division is made even more explicit when it is discovered that Edward's relationship with lady Cairnedge was the means of destroying his relationship with his twin brother. The use of twins in this case introduces the concept of division not only between individuals, but within the self.

Edward Whichcote's behaviour in the novel, the roots of which lie in a traumatic past, is reminiscent of that of lord Morven and his remorse over his wife. Lord Morven's condition was previously discussed in the context of a "haunting," and the same can be said of Edward Whichcote. In the title of the novel, and in Belorba's description of a "darkness" that haunts him, we can identify the association Edward's trauma has with the concept of the shadow. The OED's earliest citation of "shadow" as referring to this psychological aspect of self is dated 1923 - in reference to Jung (shadow, $n$. 1. d.). We have, however, already seen the shadow as a figure in MacDonald's much earlier work, Phantastes, in which it is born out of Anodos' pride. However, the shadow was a figure of the self (or part of it) long before MacDonald, being a kind of double. In Edmund Spenser's epic poem The Faerie Queene (1590), various characters (such as the nefarious Archimago in his imitation of Red Cross Knight) take on the physical forms of others. ${ }^{92}$ In terms of literary influence on George MacDonald, however, it is chiefly the doppelgänger of German Romanticism to which we should turn, with a significant example to be found amongst the works of German Romantic writer E.T.A. Hoffman (1776-1822).

Hoffman was influential on George MacDonald in a number of ways. In a letter to his wife, Louisa, dated 24 January 1856, MacDonald writes that he has spent time while recovering from a bout of illness, "meditating in spite of stupidity - and in reading Hoffman's Golden Pot again. It is delightful [...]” (Sadler 107). As Sadler adds, in a footnote to the above, "MacDonald's reading of E.T.A Hoffman's famous fairytale had a profound influence on him, inspiring him later to write Phantastes." As noted by Peter France, writing in The Oxford Guide to Literature in

\footnotetext{
92 Edgar Allan Poe's gothic story "William Wilson" (1839) is another example of the use of the dark figure of the double to represent the dark side of the self.
} 
English Translation, Hoffman's stories were available to English readers only a few years after their initial publication in German. ${ }^{93}$ The collection German Stories was translated by R.P. Gillies in 1826 (and contained as well as Hoffman, stories from de La Motte Fouque, whose Undine and The Magic Ring are also acknowledged sources of Phantastes). Walter Scott's deprecatory essay on Hoffman written in 1827, alongside Thomas Carlyle's introduction to his own translation of The Golden Pot in the same year, gave Hoffman a reputation of being "an unhealthy, morbid writer" (France 331). But translations of his stories, including Der Sandmann (1816, The Sandman) continued to appear throughout the century as "the Victorians developed a taste for the dark side of Romanticism" (France 331). The 1880s, for example, saw the publication in Britain of The Serapion Brethren, a translation by Alexander Ewing of Die Serapionsbrüder, a four-volume collection of Hoffman's tales published in 1819-21. While MacDonald makes explicit reference to just The Golden Pot, therefore, that story's impact on his writing and the wide availability of Hoffman's other stories at the time, makes it highly likely that he also read more. Central to the present discussion, for example, is 'The Sandman,' written in 1816 and included in translation in John Oxenford's anthology Tales from the German in 1844 and T.J. Bealby's Weird Tales of E.T.A. Hoffman, published in 1885.

'The Sandman' is the story of a young university student, Nathanael, who is manipulated into falling in love with an automaton, a beautiful wooden doll called Olimpia. The concept of the double is first brought to the fore when Nathanael recalls, in a letter to his best friend, Lothar, a memory he has of himself as a boy staying behind in his father's study to witness his dealings with his partner, Coppelius. Observing the two men at their alchemical work, he sees his father's face take on the same characteristics as that of Coppelius, becoming for one brief moment his mirror image: "A horrible, agonising convulsion seemed to have contorted his gentle, honest face into the hideous, repulsive mask of a fiend. He looked like Coppelius" (90). Coppelius has since become associated in his mind with the mythic figure of the Sandman. When Nathanael meets the street-vendor, Coppola, he is sure that this man is the same person as the Coppelius of his past, that that man's "figure and features are too deeply engraved on my mind for any mistake to be possible" (92). He is persuaded by his lover, Clara, and by Professor Spalanzani, however,

\footnotetext{
${ }^{93}$ Although MacDonald's knowledge of the language presumably means he could have read them immediately in their original German publication.
} 
that the two cannot possibly be the same, and is thus lured into Coppelius' and Spalanzani's trap. Wrongly convinced that the former is merely a vendor of scientific instruments, and ashamed of his previous ill-treatment of the man, Nathanael buys from him a spy-glass. Through it he sees and becomes enamoured of what he thinks is Professor Spalanzani's daughter, Olimpia, but which is actually an automaton. Despite warnings from his friends about her lack of thought or animation, however, Nathanael becomes increasingly obsessed with her, forsaking all other aspects of his life (including his love for Clara).

Despite the presence of several narrative elements recognisable to us from MacDonald's other novels, 'The Sandman' can be read as particularly pertinent to The Flight of the Shadow through its use of the double, and implied connotations of the shadow. ${ }^{94}$ In her letter to him at the beginning of the story, Clara attempts to rationalise Nathanael's obsession with the memory of Coppelius in terms of a "dark power" that has taken possession of his mind. Clara writes that Nathanael's mental obsession with the man from his past is like to "a dark power which malevolently and treacherously places a thread within us, with which to hold us and draw us down a perilous and pernicious path" (94). This "dark power," furthermore, becomes explicitly associated with the double because it "must take the same form as we do, it must become our very self; for only in this way can we believe in it and give it the scope it requires to accomplish its secret task" $(95){ }^{95}$

In MacDonald's novel, Belorba is aware that her uncle is troubled by a "darkness that haunted him" (13), and this first mention of such a concept reflects the very title of the novel itself, The Flight of the Shadow. The shadow, furthermore, is externalised in Edward's twin brother, and thus takes "the same form" as its subject. Edmund Whichcote first makes an appearance on the moors during a storm, when Belorba has ridden out in search of her uncle. She comes across "the vision of a man, plainly my uncle, a few hundred yards from me, on a gigantic gray horse" (33). Just as she moves to follow him, however, she hears her uncle's voice coming from the opposite direction. His arrival prevents her riding forward into a bog (a fate

\footnotetext{
${ }^{94}$ Examples of such familiar themes include the scientist/alchemist figure who performs experiments on those around him, as has been previously seen in the characters of Teufelsburst ("The Cruel Painter"), lord Morven (Donal Grant), and the fabled magician in Malcolm, while the interest in the automaton as informing an exploration of human identity has also been seen in Donal Grant and in the characterisation of Morven.

${ }^{95}$ Note the use of the word "secret" here, "geheime" in the original German. The concept of the secret clearly plays a central role in The Flight of the Shadow, as it is a secret that forms the basis of the trauma presented: the secret is MacDonald's notion of the "dark power" identified by Clara.
} 
recalling Clara's description of “a perilous and pernicious path” Hoffman 94).

Neither Belorba nor her uncle is able to explain the vision. Edward begins, only to fail, stuttering, "it must have been - I don't know what" (34). Belorba decides that "the vision belonged to the inexplicable" (35), believing that she has "seen [her] uncle's double." What is surprising to her is not the fact "that he should see his own double" (35), but that she has "never read of another person seeing a double at the same time with the person doubled" (36).

The double, and the implied division of the self, is crucial in both texts. In 'The Sandman' it is reinforced by the actual doubling of the character Coppelius/Coppola and the influence of Olimpia on Nathanael's self-pride. While Clara warns Nathanael that "all the terrors and horrors you describe took place only inside your head, and had very little to do with the real world outside you" (93-4), the story itself does not necessarily support her interpretation. Coppola and Coppelius do turn out to be the same (very real) person, and although Nathanael's unstable state of mind posits him perhaps as an unreliable narrator (particularly in his letters recalling the incidents of his childhood), the plot on the part of Coppola and Spalanzani to enthral him with Olimpia is posited as part of "the real world outside."

In The Flight of the Shadow, the initial appearances of Edmund Whichcote are also initially suggested as psychological phenomenon. When he appears to Belorba's fiancé, for example, John Day sees Edward riding towards him through the fog, "the man whom he knew to be at that moment confined to his bed, twenty miles away" (81). John "hardly doubt[s]" that what he sees is "an apparition," and his interpretation of the vision is portentous: a sign that Edward Whichcote, in his illness, is headed "to the tomb" (81). John becomes ill himself that very night, and, rising from his bed to go to the window, once again sees "the very effigy of [Belorba's] uncle" (82) astride his horse in the grounds. The following description of the apparition strongly suggests that it is the result of psychological trauma or stress:

When he looked again from the window, the apparition seemed fainter, and farther away, though neither horse nor rider had changed posture. [John] rubbed his eyes to see more plainly, could no longer distinguish the appearance, and went back to bed. In the morning he was in a high fever unconscious save of restless discomfort and undefined trouble. (82) 
While Edward's visions of Edmund are initially interpreted as a manifestation of his mental guilt, the circumstances surrounding John's seeing the double also suggest a disturbed mental state.

When Hoffman's Clara suggests that Nathanael's persecutions are "only inside [his] head," one must consider the actions of Coppola and Spalanzani. Their intention, in specifically singling out Nathanael to ensnare him with Olimpia, is what Clara is questioning when she claims that his fears have "very little to do with the world outside you" (93-4). She posits the idea that "once we have surrendered ourselves to the dark psychic power, it draws alien figures, encountered by chance in the outside world, into our inner selves, so that we ourselves give life to the spirit which our strange delusion persuades us is speaking from such figures" (95). What is implicit in this explanation is the role of the self: Clara sees Nathanael as ultimately responsible for what is happening in his mind. His relationship with Olimpia, furthermore, is explicitly described in terms evincing self-love. Because Olimpia is nothing but a wooden doll, what Nathanael is responding to in their interactions is clearly just his own self. As he himself claims, "only in Olimpia's love so I recognise myself" (111). The automaton's love is the love of self:

"Oh, you wonderful, profound soul," cried Nathanael, back in his room, "no one but you, you alone, understands me perfectly."

He trembled with heartfelt rapture when he considered how the marvellous harmony between his soul and Olimpia's was becoming more manifest by the day; for he felt as though Olimpia had voiced his own thoughts about his works and about his poetic gift in general; indeed, her voice seemed to come from within himself. (112)

As was the case with Nathanael's fixation on Olimpia, the self-love of the Whichcote brothers in MacDonald's novel is expressed through their obsession with a woman, but lady Cairnedge, rather than being an automaton, is very real. She is described as a seductress, who has set out to ensnare the brothers and destroy their close fraternal bond. In her machinations, lady Cairnedge becomes a composite of all three of Hoffman's characters: the scheming of Coppola and Spalanzani, combined with the physical temptation of Olimpia's female form: 
[S] uch a woman has well studied those regions of a man's nature into which, being less divine, the devil in her can easier find entrance. There, she knows him better than he knows himself; and makes use of her knowledge, not to elevate, but to degrade him. She fills him with herself, and her animal influences. She gets into his self-consciousness beside himself, by means of his self-love. Through the ever open funnel of his self-greed, she pours in flattery. By depreciation of others, she hints admiration of himself. By the slightest motion of a finger, of an eyelid, of her person, she will pay him a homage of which first he cannot, then he will not, then he dares not doubt the truth. (159-60)

Edward, looking back on his infatuation with her, describes his love as "love which is a deification of self, the foul worship of one's own paltry being" (160). Like Nathanael's obsession with Olimpia, the Whichcote brothers' relationship with lady Cairnedge is a case of delusion. Her seduction of them results in their separation, and the subsequent development in each of disturbed thought and behaviour.

Both brothers undergo trauma as a result of their relationship with lady Cairnedge. While Edward, as we have discussed, lives a life divided, isolated on the moors, and tormented by memories and guilt, Edmund's distress is given a more pathological framework. He is "placed in an asylum," having undergone "a terrible attack of brain-fever" (174). Edward's mental condition is not summarised nearly so succinctly - it must be inferred from his niece's narrative. Her necessarily childish viewpoint, alongside the fable-like atmosphere of the setting, provides an alternate view to the "brain fever." While for Edmund it involves loss of his "faculties" and a period of rehabilitation in an asylum, for Edward it is depression and visions of his "double," in an almost fantasy landscape. There are a few specific hints, however, that Edward too once suffered from more severe illness. When Edward falls from his horse and breaks his arm, Martha lets slip that she has previously "nursed him at death's door!" (53). This reference to an earlier and clearly much more serious illness correlates with Edmund's time in the lunatic asylum. ${ }^{96}$ The shared experience of illness is acknowledged by both to be psychological ("my wits were nigh gone," Edward recalls, upon finding his brother with lady Cairnedge, 168). Furthermore, when he sees lady Cairnedge again, upon a visit she makes to the farm, he claims, "it was more than my brain could handle" (109) and he has to leave her presence.

\footnotetext{
${ }^{96}$ No reference is made to such an episode as occurring in the brothers' childhood, as it is recalled by Edward up until the time that they left for college, and as Belorba herself does not remember it, it must have occurred early after Edward's return from Germany following her father's death.
} 
The compromised mental health of the Whichcote brothers as a result of lady Cairnedge and her manipulations is a fate shared by the hero of Hoffman's story. When Nathanael discovers the trick that has been played on him, "[m]adness seized him with its red-hot claws and entered his heart, tearing his mind to pieces" (114), and, like Edmund Whichcote, he is taken to "the madhouse." After leaving the asylum, supposedly cured, Nathanael suffers a relapse upon sight of his old enemy Coppelius, and throws himself from a tower. The earlier "tearing [...] to pieces" of his mind becomes literal as he lies on the ground with "his head shattered" (118). Hoffman's final description of him depicts "the tormented, self-divided Nathanael" (118).

\section{Reflecting twins}

Whereas for Edward Whichcote, discomfort comes from seeing what he believes to be his own double, for his niece Belorba, it is the sight of another's double: "that [my uncle] should see his own double," she writes, "would not in itself have much surprised me - or, indeed, that I should see it; but I had never read of another person seeing a double at the same time with the person doubled" (35-6). The application to literary tradition is made explicit, as Belorba searches for an explanation for the vision. "I tried fata morgana, mirage, parhelion, and whatever I had learned of recognised allusion" (36). These failing, however, she is "convinced that it must have another explanation than present science would afford" (36).

The answer lies of course very much within the realm of "present science," in the concept of twins. Sir Francis Galton's 1875 treatise "History of Twins" was an early exploration of the roles of nature and nurture in the development of the human individual. In this paper Galton examines ways in which "twins who were closely alike in boyhood and youth, and who were educated together for many years," become dissimilar and by what causes; similarly the converse situation, the history of twins who were exceedingly unlike in childhood, but who become "assimilated under the influence of identical nurture" (Galton 155). The Whichcote brothers are clearly an instance of the first scenario, as Edward describes his relationship with his brother thus: "My brother and I were marvellously like. Very few of our friends, none of them with any certainty, could name either of us apart - or even together' (156). 
Galton's study contains a number of anecdotes that can be seen to inform the characterisation in MacDonald's novel: for example, of a twin, "seeing his or her reflection in a looking-glass, and addressing it" (158). Reflections and doublings are crucial to the unfolding of events in The Flight of the Shadow. Such an incident as Galton describes occurs when Edward has come to collect his niece from Rising, after she was found lost on the moors by lady Cairnedge. The room in which Belorba has been left has "its walls nearly covered with great mirrors from floor to ceiling" and we learn that Belorba is "not accustomed to them" (26). Apart from the small one she keeps on her dressing-table, she has "scarcely seen a mirror" (26). Her uncle's reaction upon entering the room, however, deepens the mystery, suggesting that he is the reason for scarcity. Belorba sees him "grow white as death, and turn away, reeling as if he would fall" (26). This reaction upon seeing his own reflection is not explained at this early stage of the novel, however, but it is followed soon after by the incident already described when both Belorba and her uncle see his double.

Reflections and doublings come again to play a crucial role in the dénouement of the story. When the twins finally meet face to face, the reunion takes place in the context of a glass door. Belorba sees what she thinks is her uncle's reflection in a mirror, and is immediately concerned for him, recalling the earlier incident at Rising: "from this occurrence and from the absence of mirrors about the house, I had imagined in his life some painful story connected with a mirror" (150). What she is seeing, however, is no reflected image:

Two men had for a moment been deceived like myself: neither glass nor mirror was there - only the frame from which a swing-door had been removed. They walked each into the arms of the other, whom they had at first each taken for himself. (150)

The novel's previous doublings, both real and imagined, are thus resolved in the reunion. MacDonald's engagement with "present science" (in the form of real twins as an explanation for the otherwise psychological concept of the double), reveals his attempt to reconcile his explorations of the mind with the physical world. The mental effects of the brothers' physical separation are resolved by an equally physical reunion. 


\section{Divisions past and present}

The brothers' division at the hands of lady Cairnedge re-emerges in the novel in that woman's attempts to separate the present-day lovers, Belorba and John Day. Lady Cairnedge, already demonised through her name's negative connotations of death ("cairn-edge"), is defined as a force of division by an association with worldly knowledge. This aspect of her character works in strong contrast with Belorba's innocent ignorance. Belorba's innocence in the novel is established early on in the novel through her relationship with her uncle. Here, as has been argued, she is a childish figure defined by what she does not know. Her uncle foregrounds the trait in maintaining, "I dare not let the tale of the treacheries of a bad woman toward an unsuspecting youth, enter your ears" (159). ${ }^{97}$ He wants to keep his niece in ignorance. Lady Cairnedge, on the other hand, is "well studied," "knows," and "makes use of her knowledge" (159). Because of this she is thought of by Edward as "our [his and his brother's] common disease" (161), a form of illness infecting them, which, it has been argued, continues even after their parting. ${ }^{98}$

When John Day falls ill after seeing Edward's double, his illness, like that of both Edward and Edmund, is defined as brain-fever: "[h]is head throbbed; the room seemed turning round with him, and when it settled, he saw strange shapes in it" (82). His mother nurses him, and both John and Belorba "cannot but think, that the water in his bottle had to do with the sudden illness" (83). Lady Cairnedge's deliberate poisoning of her son thus parallels her earlier, also deliberate, effect on the Whichcote brothers. In each case of poisoning (both literal and metaphorical) the act is done with the object of division. When John escapes from her, managing to return to Belorba, all he can recall of the incident is his mother, "looking at him through a night that seemed made of blackness so solid that he marvelled she could move in it" (93). He attributes her motivation to a need for control: "Her object plainly was to plant her authority so in his very nature, that he should never think of disputing her will" (95).

Lady Cairnedge's attempts to control her son echo her much earlier manipulations of the Whichcotes in Germany, particularly because her manipulations

\footnotetext{
${ }^{97}$ In this statement Belorba's uncle is drawing attention to the well-known Victorian distinction between the angel in the house and the demon.

${ }^{98}$ In this sense, lady Cairnedge's influence on the Whichcote brothers can be seen as akin to the druguse of lord Morven in Donal Grant. That character's addiction was similarly conceived of as a "disease" (see my discussion in chapter five of this thesis).
} 
result in illness and delirium. Edward Whichcote's recollection of lady Cairnedge's effect on him is worded by a comparison of her to "the Devil," while her "treacheries of a bad woman" (159) see her "degrade" the almost sacred relationship of the brothers. He describes her as an "animal influence" and her actions are a "terrible disintegration of life" (160), revealing the "horror of corruption." She is "the old serpent," whose "poison" leads to "the foul worship of [self]." Edward now holds her in "sick contempt," and declares that "[f]rom my heart, her image was burned in a moment, as utterly as if by years of hell" (161). The strong connotations of death and decay in her characterisation become even more apparent when, after seeing her with his brother, Edward is "fascinated by the awful incongruity between [her] face, pure as the moonlight, and the charnel-house that lay unseen behind it" (169). She becomes at this point "not a woman, but a live Death" (169). Later, even her physical appearance is imbued with such a connotation; she is compared to both a "spectre" (109) and a "corpse" (169), for example, "with the staring eyes of one strangled" (169), and having "drawn, death-like lips." Lady Cairnedge's association with death is once again specifically invoked when Edward makes the claim regarding her treatment of them that "she lived to separate where Jesus died to make one" (163).

\section{The demonic mother}

The association lady Cairnedge has with poison and corruption is at odds with the idea of her as a mother. The importance of bloodlines, and the undeniable relationship between a mother and her child, is at the heart of this novel. While Mrs Stewart (Malcolm's similar portrait of an evil mother figure) remains the biological mother of the laird in MacDonald's earlier novel, her son's deformity is the mitigating factor. A deformed child is Mrs Stewart's punishment for her sexual transgressions, and his deformity in itself nullifies the bloodline in that he is unable to produce children himself. The real threat in that novel comes from the suggestion that Malcolm, too, is Mrs Stewart's biological child, and he is presumably capable of continuing the bloodline and passing on his biological inheritance to his children (as is John Day in his marriage to Belorba). When Edward sees lady Cairnedge in his house and realises that John's mother is the same woman who tormented him when he himself was a young man, he is far less keen to have him as a nephew-in-law, 
exclaiming to Belorba, "I would rather not see him! There is no occasion. It will be a great relief to me when he is able [...] to go home to his mother - or where it may suit him best" (110). The change in attitude is attributed to the realisation that "you will marry her son, and be her daughter," which is said "with a groan as of one in unutterable despair" (119). Belorba's solution, that "John must discard his mother" (120), is not enough; nor is Edward's plan to "leave the country, not to return while the woman lives" (121). It is only with the discovery, in the final chapter, that Edmund has "found perfect proof" that "lady Cairnedge was John's stepmother" (177), and not his biological mother at all, that the marriage is at last allowed to take place.

\section{The struggle for the self}

Belorba is given righteous passion and indeed violence with which to counter her adversary, whom she describes in terms decidedly non-human: "A mother!" she exclaims to Edward, "She is a hyena, a shark, a monster! Uncle, she is a devil!" (120). Furthermore, the violence described in the physical altercation between the two women is explicit:

I went softly behind [John's] mother, put my hands round her neck, and clasping them in front, pulled her backward with all my strength. We fell on the floor together, I under of course, but clutching as if all my soul were in my fingers. [...] For the moment I had the advantage, but, while determined to hold on to the last, I feared she would get the better of me, for she was much bigger and stronger, and crushed and kicked, and dug her elbows into me, struggling like a mad woman. (104-5)

Belorba is of course triumphant in her struggle for what she essentially sees as John's soul, and in a way this mirrors that earlier similar struggle between the two brothers, when they each discovered that the other had also been involved with lady Cairnedge. In that earlier situation, however, the aim of the struggle is made less (morally) explicit. Each brother has come to the realisation that he has been made "game of" (165) by the lady, and so their fight is not ultimately over her. Rather it becomes represented as a struggle within the self:

We locked in a deadly struggle, with what object I cannot tell. I do not believe either of us had an object. It was a mere 
blind conflict of pointless enmity, in which each cared but to overpower the other. Which first laid hold, which, if either, began to drag, I have not a suspicion. The next thing I know is, we were in the water, each in the grasp of the other, now rolling, now sweeping, now tumbling along, in deadly embrace. (166 italics mine)

Neither brother is distinguished from the other in terms of the description: the identical nature of their appearance comes to characterise the nature of their physical struggle. It does not matter which brother is which because they have become, in the violence of their altercation, the same individual. As a result, their subsequent separation has such disastrous consequences for their individual selves. This symbolism is foreshadowed by the destructive violence of the waterfall down which they tumble:

Down we shot together toward the sheer descent. Already we seemed falling. The terror of it over-mastered me. It was not the crash I feared, but the stayless rush through the whistling emptiness. In the agony of my despair, I pushed him from me with all my strength, striking at him a fierce, wild, aimless blow - the only blow struck in the wrestle. His hold relaxed. I remember nothing more. (166)

MacDonald's depiction of fraternal separation through violence in this scene reveals such action as defining the trauma behind Edward's pervading mental anguish throughout the novel. As such the struggle is located (as are the origins of trauma in the author's earlier novels) at that point of intersection between the physical and the spiritual. In the case of the Whichcote brothers, their physical relationship with lady Cairnedge, clearly shown to be the result of a spiritual (moral) weakness, parallels the drug use of lord Morven, the disability of the mad laird, or the physical decline of Adela Cathcart.

The scene previously described, in which the two brothers are reunited, reinforces the reading of their division as one of self. In a chapter aptly titled "Twice Two is One," the meeting takes place through the supposed medium of a mirrored reflection. Seeing her uncle on the other side of the door, when she knows he is in fact right behind her, Belorba believes that what she is seeing is his reflection in a mirror:

Then all at once the solid foundations of fact seemed to melt into vaporous dream, for as I saw the two figures come together, the one in the mirror, the other in the world, and was starting 
forward to prevent my uncle from shattering the mirror and wounding himself, the figures fell into each other's arms, and I heard two voices weeping and sobbing, as the substance and the shadow embraced. (150 italics mine)

MacDonald's idea here is clearly one of a single self, united in the embrace of the "the substance and the shadow." The depiction of the brothers "[in] each other's arms," furthermore, is a direct echo of their earlier position in falling over the waterfall, "each in the grasp of the other" (166). A reading of the brothers' separation as symbolic of division within the self is thus reinforced by the nature of the repeated image.

This unity suggestive of a single self is maintained in the final chapter of the novel. Edward and Edmund's remaining years are spent together, and not only are they physically "indistinguishable" in the eyes of others, but they adopt the same name, "each indifferently [...] ready to honour the signature, Ed. Whichcote" (179 original italics). Their separation, which necessarily led to a division within each of them, results in a reconciliation symbolic of a renewed self. The novel concludes, furthermore, with a continuation of their reconciliation into death. The resolution of crisis in the novel is once again the restoration of the spiritual, as the brothers are buried under the one tombstone, with its telling inscription: "THEY ARE NOT HERE; THEY ARE RISEN” (179). 


\section{Conclusion: \\ "The New Childhood"}

In September 1906, one year on from the death of George MacDonald at Ashtead in Surrey, Louise Collier Willcox published her commemorative essay, "A Neglected Novelist", in The North American Review. Willcox, lamenting the fact that MacDonald's novels were already thought of as "expositions of a past generation" (394), argued that his "rightful place amongst the Victorian novelists" was yet to be recognised. Over a century later John Pennington has echoed Willcox's assessment. In his 2008 essay, “'Wolff' in Sheep's Clothing: The George MacDonald Industry and the Difficult Rehabilitation of a Reputation" (2008), Pennington attributes the reluctance of critics to accept that MacDonald was a "major Victorian writer" (242) in great part to C.S. Lewis' adoption of him. This, Pennington argues, caused his subsequent "pigeonhol[ing] as a religious writer" (242), and the consequent representation of MacDonald as a Christian fundamentalist "force[d] him into a category that does not reflect his complexity" (249). What this thesis has attempted to achieve, therefore, is a sustained exploration of a crucial strand of this complexity: that of MacDonald's interest in the mind.

Close readings of the chosen novels in the light of the contemporary literary and medical context have revealed MacDonald's sustained interest in the make-up and function of the mind of the individual. MacDonald was preoccupied with the relationship between the mind and its immediate material (physical and social) context, but also (very importantly) in its potential transcendence. For MacDonald, successful development of character consists of the triumph of the spiritual over the physical, and he rests his portrayal of this development upon searching explorations of the human mind. More specifically, his novels represent the mind as mediator between the physical and the spiritual. MacDonald evokes the workings of the mind through his fictional treatment of the imagination, identity formation, the stricken conscience, madness, and drug addiction. These dimensions share the negotiation of the troublesome intersection between the physical and the spiritual, in order to achieve a stable sense of self. 
This transcendence won by the novels' characters implies MacDonald's conception of divinity. For MacDonald, the relationship between humans and God is, as in Isaiah's prophecy of the Messiah, comparable with that between a child and its parent: God is "the everlasting Father" (KJV Isa 9: 6). The resolution of character comes about through what the narrator of Adela Cathcart terms the discovery of "the new childhood of which God takes care" (415). The traditional image of God as 'the Father' is crucial in MacDonald's fiction, hence the emphasis on qualities that he termed 'childlike' in those characters that experience redemption. MacDonald's conviction that men must know that they are God's children underlies the allusions to the biblical Fall in Wilfrid Cumbermede and The Flight of the Shadow, in the mad laird's monomaniacal pursuit of his origins in Malcolm, and in Anodos' quest for identity after his father's death in Phantastes.

In his essay "The Fantastic Imagination" (A Dish of Orts 1893) MacDonald insists that in his fairytales he was writing not for children but "for the childlike, whether of five, or fifty, or seventy-five" (210). It is the childlike, according to MacDonald, who are closest to God: in order to enter the kingdom of heaven, one must become like a child. In the New Testament's book of Matthew, Jesus placed a child in the midst of his disciples and instructed them: "Except ye be converted, and become as little children, ye shall not enter into the kingdom of heaven" ( $K J V$ Mat 18: 3). MacDonald's own sermon "The Child in the Midst" (Unspoken Sermons) also emphasises the author's reliance on this important connection between the figure of the child and spiritual transcendence.

In "A Sketch of Individual Development" (A Dish of Orts), in what is, admittedly, a slight variation on his conception of God as father, he argues, "[t]here is no type so near the highest idea of relation to a God, as that of the child to his mother" (A Dish of Orts 36). Perhaps it is not surprising then that it is in his stories for children, with specifically child protagonists, that MacDonald's influence has remained (relatively) strong in both the popular and critical spheres, while his novels for adults (with the exception of Phantastes and Lilith, in the scholarly realm at least) have drifted into obscurity. His reliance on the childlike as a defining characteristic of the redeemable character necessarily functions most ideally in the child character. It is in his children's books, furthermore, as David S. Robb has noted, that "[MacDonald's] sense of a clear audience other than himself appears to 
be firmest" (114). But it is also, argues Robb, in these same stories that MacDonald is at his "most inward" (114).

Mindful of this consistent interest in the mind, I have shown that the notion of inwardness itself characterises MacDonald's adult novels. Why, then, we might ask, have the adult novels faded from popular view, while the children's stories are still read? I would argue that MacDonald's penchant for exploring both the mind and the spiritual realm as an inner landscape necessarily operates most successfully within the fantasy genre. MacDonald appears ambivalent about the subject as a vehicle for adult literature, however: as we have seen, so many of his novels fall between the poles of Victorian mimetic realism and fantasy. The pure fantasies, Phantastes and Lilith, are probably his most successful adult works. Indeed, it is within the realm of fantasy literature that MacDonald as an author of fiction is at his most assured; it is in writing fantasy that he finds, as he describes it in a letter to his wife in 1860, "the one central spot of red - the wonderful thing which, whether in a fairy story or a word or a human being, is the life and depth - whether of truth or humour or pathos - the eye to the face of it - the thing that shows the unshowable" (Sadler 133 original italics). 


\section{Works Cited}

\section{Primary Sources}

Augustine. The Confessions. Trans. Philip Burton. Everyman's Library, 2001.

Beddoes, Thomas Lovell. "Pygmalion; or The Cyprian Statuary." Classical Mythology in English Literature: A Critical Anthology. Ed. Geoffrey Miles. London: Routledge, 1999.

Blake, William. The Complete Poems. Ed. W. H. Stevenson. London: Longman, 1989.

Boccaccio, Giovanni. The Decameron. Trans. Mark Musa and Peter E. Bondanella. New York: W.W. Norton \& Company, 1977.

Brontë, Emily. Wuthering Heights. Oxford: Oxford UP, 1981.

Browning, Robert. Poetical Works 1833-1864. Ed. Ian Jack. London: Oxford UP, 1970.

Bunyan, John. The Pilgrim's Progress from this world to that which is to come. Oxford: Clarendon Press, 1928.

Carroll, Lewis. Alice's Adventures in Wonderland and Through the Looking Glass. Oxford: Oxford UP, 2009.

Cockton, Henry. The Life and Adventures of Valentine Vox, the Ventriloquist. Philadelphia: T.B. Peterson. Cornell University Library website. http://www.archive.org/details/cu31924013464874. Web. 24 February 2012.

Coleridge, Samuel Taylor. Complete Poetical Works. Ed. Ernest Hartley Coleridge. Oxford: Clarendon Press, 1912.

Collins, Wilkie. The Moonstone. Harmondsworth: Penguin Books, 1955.

---. The Woman in White. London: Oxford UP, 1975.

Conolly, John. "The Physiognomy of Insanity." The British Journal of Psychiatry 6 (1860): 207-233.

Cowley, Abraham. The Works of Mr Abraham Cowley. London: J.M. for Henry Herringman, 1669. EEBO.

Dickens, Charles. A Christmas Carol. London: Chapman and Hall, 1903.

---. David Copperfield. Oxford: Oxford University Press, 1981. 
Eliot, George. Middlemarch. Ed. David Carroll. Oxford: Clarendon Press, 1986

Fletcher, Phineas. The Purple Island; or, The Isle of Man. Renascence Editions website. 21 November 2009. http://www.luminarium.org/renascenceeditions/island/. Web. 18 August 2010.

Gower, John. Confessio Amantis. New York: Holt, Rinehart and Winston, 1968.

Haight, Gordon S. The George Eliot Letters. Vol 4. New Haven: Yale University Press, 1954.

Hegel, G.W.F. Lectures on the Philosophy of Spirit, 1827-8. Trans. Robert R. Williams. Oxford: Oxford UP, 2007.

Hoffman, E.T.A. The Golden Pot and Other Tales. Trans. Ritchie Robertson. Oxford: Oxford UP, 1992.

Jean Paul. Titan: A Romance. Trans. Charles T. Brooks. Boston: Ticknor and Fields, 1864.

Kingsley, Charles. Two Years Ago. London: Macmillan, 1888.

Klopstock, Friedrich Gottlieb. The Messiah. Trans. Joseph Collyer. London: J. Dodsley, F. Newbery, and J. Collyer, 1766. ECCO.

Labyrinth. Dir. Jim Henson. Perf. David Bowie, Jennifer Connelly. 1986. DVD. Sony Pictures Home Entertainment, 1999.

Longfellow, Henry Wadsworth. "Tales of a Wayside Inn." The Complete Poetical Works of Henry Wadsworth Longfellow. London: George Routledge and Sons, Limited, 1895. 204-286.

MacDonald, George. Adela Cathcart. London: George Routledge and Sons, Limited, n.d.

---. At the Back of the North Wind. London: Blackie and Son Limited, n.d.

---. A Dish of Orts: Chiefly Papers on the Imagination, and on Shakspere. Illinois: Book Jungle, 2008.

---. Donal Grant. London: Kegan Paul, Trench, Trübner \& Co., 1890.

---. The Flight of the Shadow. Gloucester: Dodo Press, n.d.

---. Malcolm. London: Kegan Paul, Trench, Trübner \& Co., n.d.

---. The Marquis of Lossie. London: Kegan Paul, Trench, Trübner \& Co., n.d.

---. The Portent. San Francisco: Harper \& Row, 1979. 
---. Phantastes and Lilith. London: Victor Gollancz Ltd, 1962.

---. The Princess and Curdie. London: Claremont Books, 1995.

---. The Princess and the Goblin. London: Puffin Books, 1996.

---. Ranald Bannerman's Boyhood. Ægypan Press, n.d.

---. Robert Falconer. London: Cassell and Co., 1927.

---. Salted With Fire. London: Hurst and Blackett, n.d.

---. Sir Gibbie. London: Hurst and Blackett, n.d.

---. Unspoken Sermons. Radford, VA: Wilder Publications, 2008.

---. Wilfrid Cumbermede: An Autobiographical Story. London: Kegan Paul, Trench \& Co., n.d.

Milton, John. Areopagitica; a speech for the liberty of unlicensed printing, to the Parliament of England. London, 1644. EEBO

---. Complete Poetical Works. Ed. H.C. Beeching. London: H. Milford, Oxford UP, 1913.

Novalis. "Aphorisms." Trans. Frederic H. Hedge. The German Classics of the Nineteenth and Twentieth Centuries. Vol 4. Ed. Kuno Francke. Kessinger Publishing, 2004: 104 - 107.

Ovid. Metamorphoses. Trans. A.D. Melville. Oxford and New York: Oxford UP, 1986.

Plato. The Republic. Trans. Desmond Lee. London: Penguin Books, 1987.

de Quincey, Thomas. Confessions of an English Opium Eater. London: Macmillan and Co., 1915.

Reade, Charles. Hard Cash. London: Collins, n.d.

Shakespeare, William. Macbeth. Ed. A.R. Braunmuller. Cambridge: Cambridge UP, 2008.

---. The Tragedy of King Lear. Cambridge: Cambridge UP, 2005.

Shelley, Percy Bysshe. Complete Poetical Works. Ed. Thomas Hutchinson. London: Oxford UP, 1952.

Spenser, Edmund. The Faerie Queene. Ed. Thomas P. Roche, Jr. Harmondsworth and New York: Penguin Books, 1978. 
Sutton, Henry. "Man.” University of Virginia Library website. http://xtf.lib.virginia.edu/xtf/view?docId=chadwyck ep/uvaGenText/tei/chep 3.1746.xml;chunk.id=d18;toc.depth=1;toc.id=d3;brand=default;query=Apollon ius,\#1. Web. 18 August 2010.

von Schubert, Gotthilf Heinrich. Die Symbolik des Traumes. Oxford University Archive website. http://www.archive.org/details/diesymbolikdest00rankgoog. Web. 19 October 2011.

The Wisdom of Solomon. Edinburgh: 1755. ECCO.

Wordsworth, William. The Prelude, 1798-1799. Ed. Stephen Parrish. Ithaca, New York: Cornell UP, 1977.

\section{Secondary Sources}

Anstie, F.E. Stimulants and Narcotics. London: Macmillan, 1864.

Bayer, Mark. "The Distribution of Political Agency in Phineas Fletcher's Purple Island." Criticism, 44.3 (2002): 249-270.

Berridge, Virginia and Griffith Edwards. Opium and the People: Opiate Use in Nineteenth-Century England. London and New York: Allen Lane/St Martin's Press, 1981.

Blandford, George Fielding. Insanity and its Treatment. Arno Press, 1976.

Broome, F. Hal. "The Scientific Basis of George MacDonald's Dream-Frame." The Gold Thread: Essays on George MacDonald. Ed. William Raeper.

Edinburgh: Edinburgh UP, 1990: 87-108.

Byrne, Katherine. Tuberculosis and the Victorian Literary Imagination. Cambridge: Cambridge UP, 2011.

Bynum, W.F., Roy Porter and Michael Shepherd, eds. The Antatomy of Madness: Essays in the History of Psychiatry. Vol III. London: Routledge, 1988.

Carter, Robert Brudenell. On the Pathology and the Treatment of Hysteria. London: John Churchill, 1852.

Clements, Robert J. “Anatomy of the Novella.” Boccaccio's Decameron. Eds. Mark Musa and Peter E. Bondanella. New York: W.W. Norton and Co., 1977.

Coats, Joseph. A Manual of Pathology. $4^{\text {th }}$ edition. Rev. Lewis R. Sutherland. London: Longmans, Green, and Co., 1900. 
Collins, Thomas J. and Vivienne J. Rundle, eds. The Broadview Anthology of Victorian Poetry and Poetic Theory. Ontario: Broadview Press, 2005.

Cusick, Edmund. "MacDonald and Jung." The Gold Thread: Essays on George MacDonald. Ed. William Raeper. Edinburgh: Edinburgh UP, 1990: 56-86.

Dormandy, Thomas. The White Death: A History of Tuberculosis. New York: New York UP, 2000.

Dubos, René and Jean Dubos. The White Plague: Tuberculosis, Man, and Society. New Brunswick and London: Rutgers UP, 1987.

Fink, Larry E. "'Natural History - The Heavenly Sort': George MacDonald's Integration of Faith and Reason." "A Noble Unrest": Contemporary Essays on the Work of George MacDonald. Ed. Jean Webb. Newcastle: Cambridge Scholars Publishing, 2007: 59-66.

Foucault, Michel. The Birth of the Clinic: An Archaeology of Medical Perception. Translated by A.M. Sheridan Smith. New York: Pantheon Books, 1973.

---. Madness and Civilisation: A History of Insanity in the Age of Reason. New York: Vintage Books, 1988.

Freud, Sigmund. "Mourning and Melancholia." Collected Papers. Vol IV. London: Hogarth Press, 1925: 152-170.

Gilman, Sander L., Helen King, Roy Porter, G.S. Rousseau and Elaine Showalter. Hysteria Beyond Freud. California: University of California Press, 1993.

Gray, William N. "George MacDonald, Julia Kristeva, and the Black Sun." Studies in English Literature 1500-1900 36:4 (Autumn 1996): 877-893.

---."'Crossover fiction' and narrative as therapy: George MacDonald's Adela Cathcart." Barnboken 2 (2009): 45-57.

Hall, Donald, E.,ed. Muscular Christianity: Embodying the Victorian Age. Cambridge: Cambridge UP, 2006.

Hardin, James N., ed. Reflection and Action: Essays on the Bildungsroman. Columbia: University of South Carolina Press, 1991.

Hassan, John. The Seaside, Health and the Environment in England and Wales since 1800. Aldershot: Ashgate Publishing, 2003.

Hein, Rolland. The Spiritual Vision of George MacDonald. Michigan: Wm. B. Eerdmans Publishing, 1982.

---. Christian Mythmakers. Chicago: Cornerstone Press, 2002.

Huet, Marie Hélène. Monstrous Imagination. Cambridge: Harvard UP, 1993. 
Houston, Robert A. "The Face of Madness in Eighteenth- and early NineteenthCentury Scotland." Eighteenth Century Life 27:2 (2003): 49-66.

Inglis, Brian. Fringe Medicine. London: Faber and Faber, 1964.

Jeffrey, David Lyle, ed. A Dictionary of Biblical Tradition in English Literature. Michigan: W. B. Eerdmans, 1992.

Kahn, Coppélia. "The Absent Mother in 'King Lear."' Rewriting the Renaissance: Discourses of Sexual Difference in Early Modern Europe. Eds. Margaret W. Ferguson, Maureen Quilligan, and Nancy J. Vickers. Chicago and London: The University of Chicago Press, 1986: 33-49.

Kane, H. H. The Hypodermic Injection of Morphia: Its History, Advantages and Dangers. New York: Chas. L. Bermingham \& Co., 1880. Open Library website. 1 April 2008.

http://www.archive.org/stream/hypodermicinjec00kanegoog\#page/n5/mode/2u p. Web. 6 January 2010.

Kearns, Michael. Metaphors of Mind in Fiction and Psychology. Lexington: University Press of Kentucky, 1987.

Koopman, Jennifer. "'The Cruel Painter' as a Rewriting of the Shelley-Godwin Triangle." North Wind: Journal of MacDonald Studies, 26 (2007): 48-76.

---. Redeeming Romanticism: George MacDonald, Percy Shelley, and Literary History. A thesis submitted to McGill University in partial fulfilment of the requirements of the degree of Doctor of Philosophy. Montrèal: Department of English, McGill University, 2006.

Levinstein, Eduard. Morbid Craving for Morphia. Ayer Publishing, 1981.

Lewis, William Bevan. A Textbook of Mental Diseases. Philadelphia: P. Blakiston, Son, and Company, 1890.

MacDonald, Greville. George MacDonald and his Wife. London: George Allen \& Unwin, 1924.

Maudsley, Henry. The Physiology of Mind. London: Macmillan and Co., 1876.

McCarthy, John A. "Criticism and Experience: Philosophy and Literature in the German Enlightenment." Philosophy and German Literature, 1700-1990. Ed. Nicholas Saul. Cambridge: Cambridge UP, 2002.

McGillis, Roderick. "Phantastes and Lilith: Femininity and Freedom." The Gold Thread: Essays on George MacDonald. Ed. William Raeper. Edinburgh: Edinburgh UP, 1990: 31-55. 
---. "Childhood and Growth: George MacDonald and William Wordsworth." Romanticism and Children's Literature in Nineteenth-Century England. Ed. James Holt McGavran, Jr. Georgia: University of Georgia Press, 1991: 150167.

McLaren, Scott. "Saving the Monsters? Images of Redemption in the Gothic Tales of George MacDonald." Christianity and Literature 55:2 (Winter 2006): 245270.

Musa, Mark and Peter E. Bondanella. "Meaning of The Decameron." The Decameron. Eds. Mark Musa and Peter E. Bondanella. New York: W.W. Norton and Co., 1977.

Pennington, John. "Muscular Spirituality in George MacDonald's Curdie Books." Muscular Christianity: Embodying the Victorian Age. Ed. Donald E. Hall. Cambridge: Cambridge UP, 2006.

---. “'Wolff' in Sheep's Clothing: The George MacDonald Industry and the Difficult Rehabilitation of a Reputation." George MacDonald: Literary Heritage and Heirs. Ed. Roderick McGillis. Wayne, Pennsylvania: Zossima Press, 2008.

Raeper, William. George MacDonald. Tring: Lion Publishing, 1987.

---., Ed. The Gold Thread: Essays on George MacDonald. Edinburgh: Edinburgh UP, 1990.

Robb, David S. George MacDonald. Edinburgh: Scottish Academic Press, 1987.

---. "George MacDonald's Scottish Novels." The Gold Thread: Essays on George MacDonald. Ed. William Raeper. Edinburgh: Edinburgh UP, 1990: 12-30.

Rosen, David. "The Volcano and the Cathedral: Muscular Christianity and the Origins of Primal Manliness." Muscular Christianity: Embodying the Victorian Age. Ed. Donald E. Hall. Cambridge: Cambridge UP, 1994: 17-44.

Saintsbury, Elizabeth. George MacDonald: A Short Life. Edinburgh: Canongate Publishing, 1987.

Saul, Nicholas, ed. Philosophy and German Literature, 1700-1990. Cambridge: Cambridge UP, 2002.

Scull, Andrew. "Moral Treatment Reconsidered." Madhouses, Mad-Doctors, and Madmen. Ed. Andrew Scull. London: Athlone Press, 1981: 105-115.

---. Madhouses, Mad-Doctors, and Madmen, ed. London: Athlone Press, 1981.

Sontag, Susan. Illness as Metaphor. New York: Farrar, Straus and Giroux, 1978.

Spenser, Herbert. First Principles. London: Williams \& Norgate, 1904. 
Suzuki, Akihito. "The State, Family, and Insane in Japan, 1900-1945. The Confinement of the Insane: International Perspectives, 1800-1965. Eds. Roy Porter and David Wright. Cambridge and New York: Cambridge UP, 2003.

Talairach-Vielmas, Laurence. Moulding the Female Body in Victorian Fairy Tales and Sensation Novels. Hampshire: Ashgate Publishing, 2007.

Veith, Ilza. Hysteria: The History of a Disease. Chicago and London: University of Chicago Press, 1965.

Webb, Jean, ed. "A Noble Unrest”: Contemporary Essays on the Work of George MacDonald. Newcastle: Cambridge Scholars Publishing, 2007.

Weisenthal, Chris. Figuring Madness in Nineteenth-Century Fiction. New York, London: St Martin's Press; Macmillan, 1997.

Willcox, Louise Collier. “A Neglected Novelist." The North American Review 183: 598 (September 1906): 394-403.

Wolff, Robert Lee. The Golden Key: A Study of the Fiction of George MacDonald. New Haven: Yale UP, 1961. 